\title{
Review
}

Intervirology

Intervirology 2016;59:74-110

DOI: $10.1159 / 000449503$
Received: May 25, 2016

Accepted: August 30, 2016

Published online: November 10, 2016

\section{The True Story and Advantages of RNA Phage Capsids as Nanotools}

\author{
Paul Pumpens ${ }^{\mathrm{a}}$ Regina Renhofa ${ }^{\mathrm{a}}$ Andris Dishlers $^{\mathrm{a}}$ Tatjana Kozlovska $^{\mathrm{a}}$ \\ Velta Ose $^{a}$ Peter Pushko ${ }^{c}$ Kaspars Tars ${ }^{a, b}$ Elmars Grens ${ }^{a}$ \\ Martin F. Bachmann ${ }^{d, e}$ \\ a Latvian Biomedical Research and Study Centre, and ${ }^{b}$ Faculty of Biology, Department of Molecular Biology,

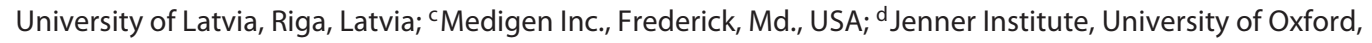 \\ Oxford, UK; ' University Institute of Immunology, University of Bern, Inselspital, Bern, Switzerland
}

\author{
Key Words \\ RNA phages - Coat proteins - Virus-like particles . \\ Self-assembly · 3D structure - Vaccines · Immunology · \\ Nanocontainers · Drug delivery $\cdot$ Viral nanotechnology
}

nological RNA phage VLP applications, such as experimental vaccines constructed by genetic fusion and chemical coupling methodologies, nanocontainers for targeted drug delivery, and bioimaging tools.

(c) 2016 S. Karger AG, Basel

\begin{abstract}
RNA phages are often used as prototypes for modern recombinant virus-like particle (VLP) technologies. Icosahedral RNA phage VLPs can be formed from coat proteins (CPs) and are efficiently produced in bacteria and yeast. Both genetic fusion and chemical coupling have been successfully used for the production of numerous chimeras based on RNA phage VLPs. In this review, we describe advances in RNA phage VLP technology along with the history of the Leviviridae family, including its taxonomical organization, genomic structure, and important role in the development of molecular biology. Comparative 3D structures of different RNA phage VLPs are used to explain the level of VLP tolerance to foreign elements displayed on VLP surfaces. We also summarize data that demonstrate the ability of CPs to tolerate different organic (peptides, oligonucleotides, and carbohydrates) and inorganic (metal ions) compounds either chemically coupled or noncovalently added to the outer and/or inner surfaces of VLPs. Finally, we present lists of nanotech-
\end{abstract}

\section{Family of RNA Phages}

\section{Taxonomy}

Pili-specific RNA phages, currently the most promising virus-like particle (VLP) carriers, are nonenveloped, spherical viruses with $\mathrm{T}=3$ icosahedral symmetry and diameters ranging from approximately 28 to $30 \mathrm{~nm}$. RNA phage particles are composed of 178 chemically identical coat protein (CP) molecules, or $89 \mathrm{CP}$ dimers, and one copy of maturation, or A, protein, which replaces a single $\mathrm{CP}$ dimer. The phage's monopartite, positive-sense, single-stranded (plus-ssRNA) genome is approximately $4 \mathrm{~kb}$ in size and serves as messenger RNA for the synthesis of the capsid-forming $\mathrm{CP}$ as well as three other viral proteins: the maturation, replicase, and lysis proteins (fig. 1).

The first Escherichia coli-infecting RNA phages that played an important role in VLP technology were identified in the early 1960s and included the f2 [1], MS2 [2],

\section{KARGER}

E-Mail karger@karger.com www.karger.com/int (c) 2016 S. Karger AG, Basel

0300-5526/16/0592-0074\$39.50/0
Paul Pumpens

Baznicas 27/29-22

LV-1010 Riga (Latvia)

E-Mail paul@biomed.lu.lv 
R17 [3], fr [4], M12 [5], and Q $\beta$ [6] phages. The early history and basic properties of RNA phages were reported in detail in two books $[7,8]$ and in one original review [9].

Later, other RNA phages that became more common as VLP carriers were described, including the E. coli phages SP, FI [10] and GA [11], the Caulobacter crescentus phage $\varphi$ CB5 [12], the Pseudomonas aeruginosa phage PP7 [13], the broad host range, P-pili-specific phage PRR1 [14], and the Acinetobacter phage AP205 [15, 16].

According to the most current ICTV taxonomy release [17], RNA phages are members of the family Leviviridae. This family has not been assigned to any higher viral order and comprises two genera: Levivirus, which includes the species BZ13 (first mentioned in Inokuchi et al. [18]) and MS2, and Allolevivirus, which includes the species FI and $\mathrm{Q} \beta$. Other common RNA phages were mentioned in earlier ICTV taxonomy releases until 1998.

According to current NCBI Taxonomy browser information [19], the Levivirus genus consists of the BZ13 and MS2 species. The BZ13 species includes the phages GA and JP34, among others, as subspecies, while the MS2 species includes the phages $\mathrm{f} 2$, fr, M12, and R17, among others. The Levivirus genus also includes some unclassified members such as the Acinetobacter phage AP205 and the Pseudomonas phage PP7.

Based on the NCBI Taxonomy classification of the Allolevivirus genus, the FI and $\mathrm{Q} \beta$ species include FI group subspecies (including phages SP, TW19, and TW28, among others) and $\mathrm{Q} \beta$ group subspecies (including phages MX1 and ST, among others). Some species, including the Caulobacter phage $\varphi \mathrm{CB} 5$ and P-pili-specific phages, predominantly the Pseudomonas phage PRR1, remain in the NCBI classification as unclassified Leviviridae members.

\section{Sero- and Genogroups}

Generally, the current classification is based on serological typing [20] and has divided RNA phages into four serogroups, namely, serogroups I to IV [for a detailed discussion, see 21]. This classification scheme has been confirmed by studies of the template specificity of RNA phage replicases [22], genetic analysis [23,24], and physiochemical data, e.g. by resistance to high hydrostatic pressure [25]. The RNA phages MS2, GA, Q $\beta$, and SP are typically recognized as reference strains for the sero- and genogroups I, II, III, and IV, respectively. Therefore, group I and II members belong to the Levivirus genus, while serogroup III and IV members belong to the Allolevivirus genus. Ecological and wastewater studies have revealed that RNA phages from groups II and III are associated

RNA Phage Capsids as Nanotools with human waste, whereas group I and IV members are predominantly associated with animal waste [21]. However, this distribution is not absolute and requires further refinement [26, 27].

The genomic structures of the Levivirus and Allolevivirus genera members demonstrate some differences (fig. 1). In addition to the standard maturation protein, $\mathrm{CP}$, and replicase subunit, the Allolevivirus genome encodes a C-terminally extended CP known as the minor A1 protein, which appears as a result of ribosomal readthrough of a leaky opal termination codon of the $\mathrm{CP}$ gene [28] and is essential for the formation of viable $Q \beta$ particles in vivo [29-31]. The A1 protein is incorporated in 3-10 copies per virion, or in 12 copies in accordance with a recent study [32], it is required for infection, but its precise function is not known [for more references, see 8 , 29-33]. A recent electron microscopy visualization of foreign epitopes carried by A1 protein within infectious $Q \beta$ particles showed that the A1 protein molecules are occupying corners of the $\mathrm{Q} \beta$ icosahedron [32]. The lysis protein forms pores in the cellular membrane, leading to activation of autolysins and, eventually, cell lysis [34].

\section{Drawbacks of Classification}

The current NCBI classification comprising two genera as well as four serogroups are adequate in the case of coliphages; however, attempts to assign phages from other hosts to Levivirus, Allolevivirus, or 'unclassified' members have been rather artificial and lack solid rationale aside from historical considerations. In our opinion, a new classification system based solely on sequence similarities should be employed. For example, Levivirus and Allolevivirus genera could be left only for coliphages, and new genera could be introduced based on sequence similarities among conserved replicase protein sequences.

\section{Unique Scientific Role}

RNA phages were the first classic models used in early molecular biology and are considered instrumental in the making of molecular biology' [35]. They provided the scientific community with purified RNA and markedly contributed to the decryption of the genetic code, the understanding of RNA translation and replication mechanisms, and the elucidation of virus-host interactions and the self-regulation of biological systems [for details and references, see 7-9, 35]. The RNA phage MS2 was the first organism with a fully sequenced genome [36]. The capsids of the RNA phages R17 and $\mathrm{f} 2$ were among the first observed virions with resolved icosahedral symmetry 
Fig. 1. Genomic structure of RNA phages that have been used in viral nanotechnology applications. a Locations of the $\mathrm{CP}$ genes (colored in dark pink) within the genomes of RNA phages. The genomes are shown to scale and are in alphabetical order. AP and A2 are maturation proteins. $\mathrm{RP}=$ Replicase; $\mathrm{L}=$ lysis protein. The $\mathrm{Q} \beta$ genome does not encode L protein. The A1 extension of the $\mathrm{Q} \beta \mathrm{CP}$ is indicated in light pink. The numbering used for $\mathrm{CP}$ aa residues is indicated for each species. The data are compiled from the NCBI taxonomy browser for the Leviviridae family [19]. The experimentally determined lengths of phage CPs are always one aa residue shorter than the actual proteins because the $\mathrm{N}$ terminal methionine is cleaved off in infected E. coli cells. This explains the discrepancies in CP numbering in different published works. b The phenogram of the CP aa sequences obtained by Clustal V alignment in the MegAlign program from DNASTAR Lasergene.

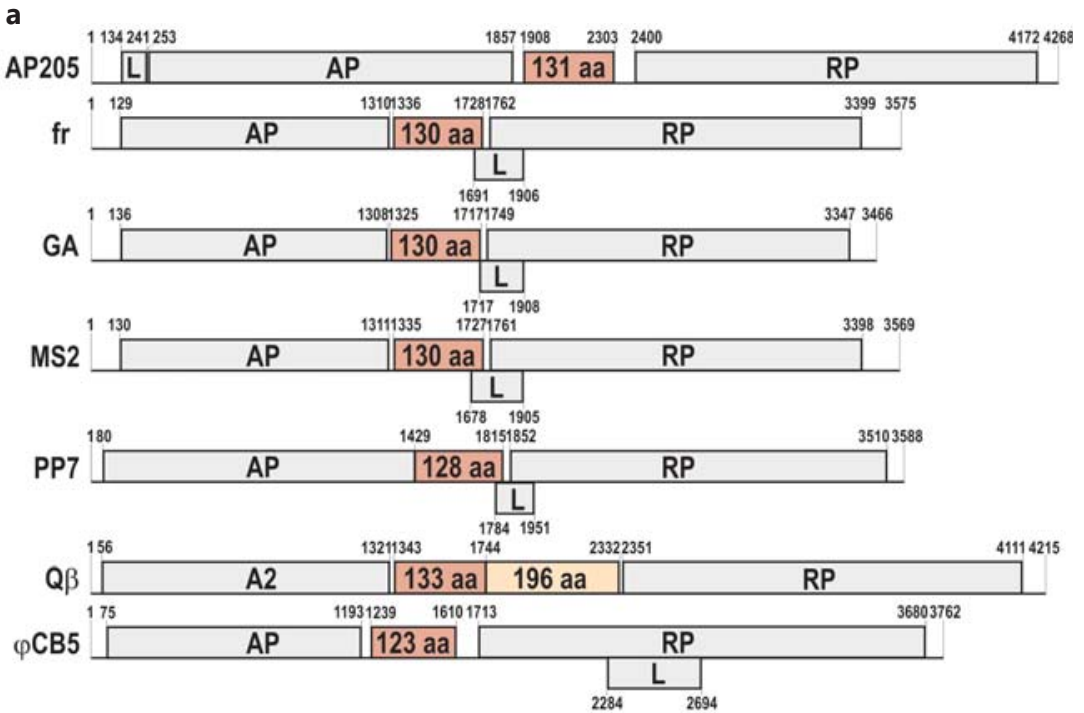

b

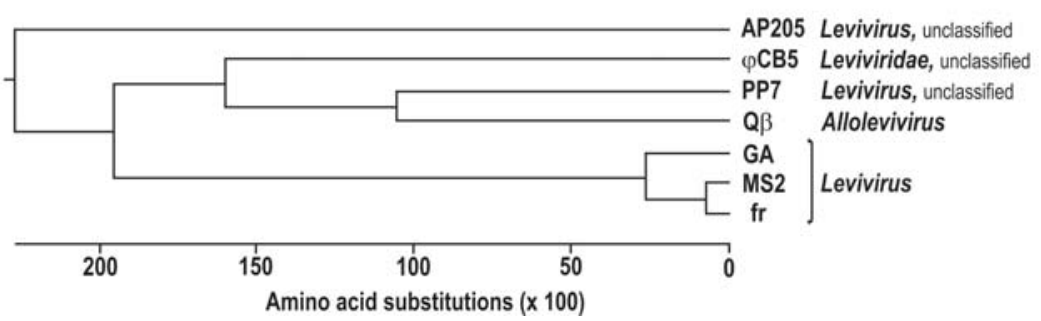

[37], after the classical work by Caspar and Klug [38] on the structural analysis of plant viruses. RNA phages have also presented substantial background for studies on phylogeny and genome evolution [33].

Furthermore, RNA phages paved the way for antisense-based gene therapy via the generation of the socalled 'mRNA-interfering complementary RNA (micRNA) immune system' for the prevention of phage SP proliferation $[39,40]$.

RNA phages, especially the phage MS2, have also markedly contributed to ecological and disinfection studies via their use in the development of numerous physical and chemical methods for genome inactivation, from early attempts [41] to recent systematic studies [42]. The RNA phages MS2, GA, Q $\beta$, FI, SP, and PP7 are still efficiently used as surrogate models for the control of viral contamination in food production and storage, in industrial and clinical applications, and on health care personnel [for two recent examples, see 43,44], in addition to serving as viral and microbial source tracking materials in wastewater [for references and discussion, see 45]. It is broadly accepted that RNA phages are fully adequate surrogates for human enteroviruses in studies of virus contamination $[46,47]$. RNA phages are also often used as internal controls of extraction/amplification efficiency in modern RT-PCR kits for the surveillance of emerging pathogens, including the Ebola virus [48].

\section{CP as a Repressor}

RNA phages were the first examples of an 'operon' mechanism of gene regulation by 'self proteins [49]. This mechanism can be described as a full-cycle regulated biological system, where gene regulation is performed by two phage proteins: $\mathrm{CP}$ and replicase $[50,51]$. The CPs of most RNA phages have been shown to repress translation of the replicase gene by binding to an RNA hairpin as an operator at the start site of the replicase gene [7-9]. The ability of RNA phage $\mathrm{CP}$ to recognize the corresponding operator stem-loop led to the development of an efficient methodology based on the tethering of CP to 
CP-operator-tagged RNAs. Using this technique, mRNAs that are tagged with the operator sequence are highly specifically recognized by $\mathrm{CP}$, which can be fused to fluorescent or other functional probes. This CP-operator tethering methodology enables imaging of the processing, export, localization, translation, and degradation of operator-tagged mRNA in living cells (see the review by Lampasona and Czaplinski [52] and a recent protocol from Bensidoun et al. [53] as an example). Furthermore, the tethering technique allows affinity purification of the desired RNA-protein complexes [54]. The tethering methodology mostly exploits the CP-operator composition from phage MS2, although PP7-based methodology, including the use of simultaneous MS2 and PP7 two-color labeling [55], has been recently described. A phage R17-based technique was also used in the early development of the tethering approach [56]. It is noteworthy that the tethering technique has recently been applied to further develop the highly productive CRISPR-Cas9 technology [57].

\section{Expression and Structural Investigations}

\section{Expression of CP Genes}

The expression of RNA phage CP genes in E. coli led to the high-level production of correctly self-assembled icosahedral capsids that were morphologically and immunologically indistinguishable from virions in the case of MS2 [58, 59] and fr [60] of group I, JP34, an intermediate between groups I and II [61], GA of group II [62], Q $\beta$ of group III [63], SP of group IV [64], the unclassified Levivirus members PP7 $[65,66]$ and AP205 $[67,68]$, and the unclassified Leviviridae phages PRR1 [69] and $\varphi \mathrm{CB} 5$ [70]. It is noteworthy that not only E. coli cells but also the E. coli-based cell-free translation system can be used for efficient in vitro production of MS2 VLPs $[71,72]$.

Coinfection with two phages led to the production of mixed particles only in the case of the closely related phages MS2 and fr from the serogroup I and not in the case of the more distantly related phages fr and GA; however, the reassembly of recombinant fr and GA CP dimers in vitro allowed the generation of the mixed particles in both spherical and rod-like configurations [73].

Highly efficient production of VLPs was also achieved in the yeast species Saccharomyces cerevisiae and Pichia pastoris for phages MS2 [74], Q $\beta$ [75], GA [76], fr, AP205, PP7, and $\varphi$ CB5 [77]. Attempts to prepare RNA phage SP VLPs in S. cerevisiae and P. pastoris were unsuccessful [77].

RNA Phage Capsids as Nanotools

\section{D Structures of Phage Capsids}

As mentioned above, the RNA phages R17 and $\mathrm{f} 2$ played a unique role in revealing the virion's icosahedral symmetry [37]. The place of RNA phages in the global history of viral architecture was presented in a recent review [78]. Early electron microscopy studies demonstrated clear paracrystalline arrays of virions in E. coli cells infected with the RNA phages f2 [79], $\mu 2$ [80], and R17 [81]. Similar paracrystalline structures were later found in E. coli cells expressing the $\mathrm{CP}$ gene and producing VLPs; for example, see the electron micrograph of a slice of a cell filled with phage $Q \beta$ VLPs in Pumpens and Grens [82].

Fine 3D structures of the most typical RNA phage representatives have been resolved by X-ray crystallography (fig. 2) and were found to be very similar, despite the marked diversity in the primary structures of their CPs (fig. 1). The first 3D structure resolved was for MS2 virions. At the time, this structure showed no similarity to any other known viruses or proteins of any origin. The MS2 virion structure was first determined at a resolution of $3.3 \AA$ [83-85] and then refined to a resolution of $2.8 \AA$ [86]. Next, the crystal structure of an MS2 capsid with amino acid (aa) exchanges in the FG loop was resolved [87]. Historically, the first phage MS2 crystals and preliminary X-ray examination data were obtained in Walter Fiers' lab in 1979 [88].

According to the 3D structure of MS2, the $180 \mathrm{CP}$ subunits of the virion are arranged in dimers as initial building blocks and form a lattice with a $\mathrm{T}=3$ triangulation number (fig. 2). The CP subunit consists of a five-stranded $\beta$-sheet facing the inside of the particle and a hairpin and two $\alpha$-helices on the outside.

The structure of a recombinant capsid of the RNA phage fr was determined by X-ray crystallography at a resolution of $3.5 \AA$ and was shown to be identical to the protein shell of the native virus $[89,90]$. This was followed by determination of the structure of the GA phage, which showed some structural differences compared to MS2 and fr phage/VLPs, especially in the $\mathrm{N}$ - and C-terminal regions [91]. The structures of virions and recombinant capsids of the $\mathrm{Q} \beta$ phage were resolved at a resolution of $3.5 \AA[92,93]$. These structures differed from previously determined RNA phage structures by the presence of stabilizing disulfide bonds on each side of the flexible FG loop, which covalently links CP dimers. A comparison with the structure of the related phage MS2 shows that although the fold of the $\mathrm{Q} \beta \mathrm{CP}$ is very similar, the details of the protein-protein interactions are completely different [93]. 


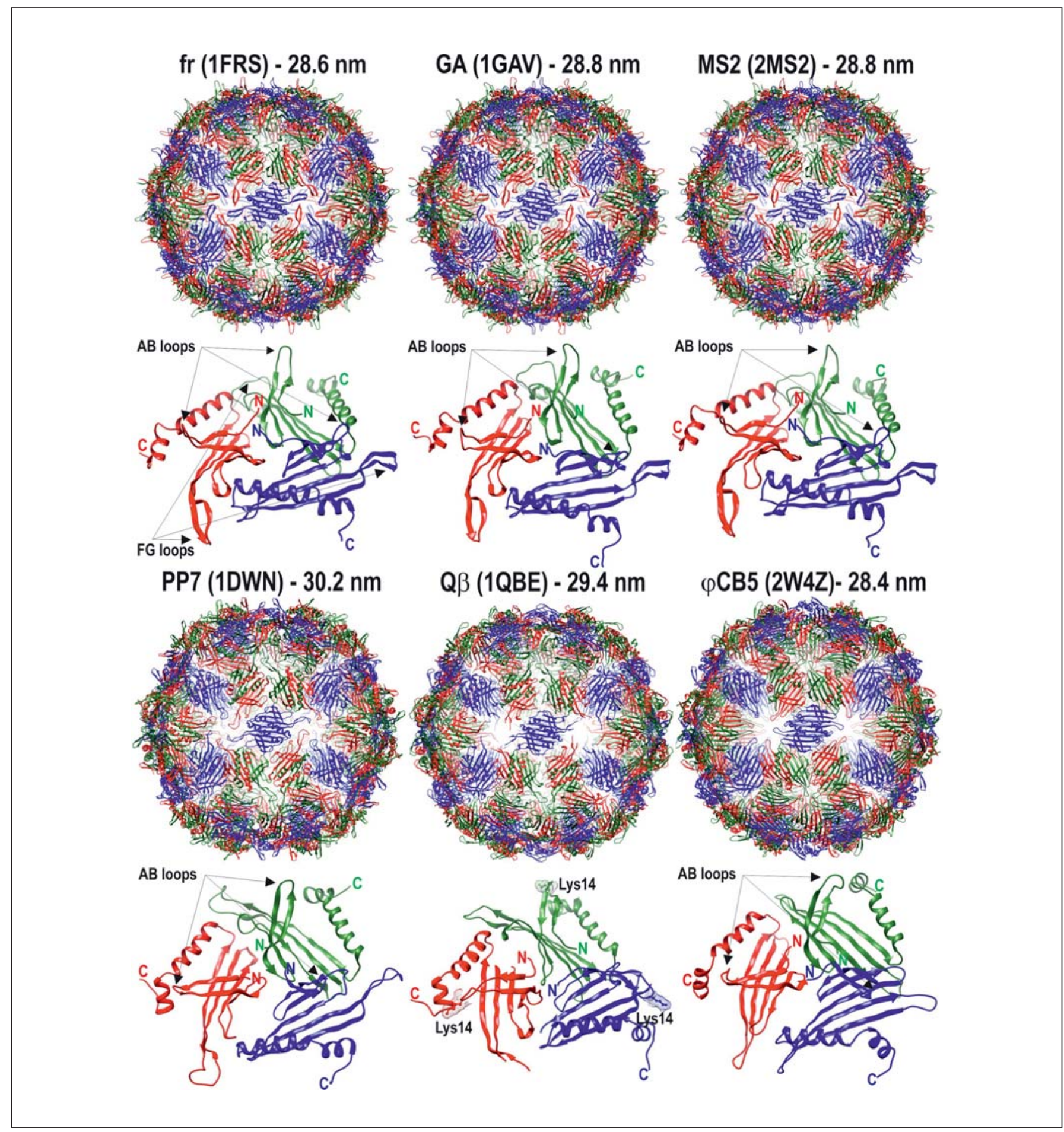

Fig. 2. Crystal structures of RNA phages that have been used as VLP carriers. The structures are presented in alphabetical order with their protein data bank IDs shown in parentheses and the outer diameters indicated for each species. The AB loops are exposed on the full-capsid surfaces. Also shown are the corresponding trimeric asymmetric units with the indicated $\mathrm{N}$ - and C-termini. The outer surface is oriented towards the reader. The AB loops are indicated by arrows. The $\mathrm{Q} \beta \mathrm{AB}$ loops are distinguished by Lys14 residues, which are indicated by the shaded areas. The CP chains $\mathrm{A}, \mathrm{B}$ and $\mathrm{C}$ are indicated in red, green, and blue, respectively. The structural data are compiled from the VIPERdb (http://viperdb.scripps.edu) database [389] and were visualized using Chimera software [390].
78

Intervirology 2016;59:74-110

DOI: $10.1159 / 000449503$
Pumpens/Renhofa/Dishlers/Kozlovska/ Ose/Pushko/Tars/Grens/Bachmann 
Fig. 3. Differences in CP structures between the AP205 and MS2 phages. The overall folds of the CP dimers (top) are similar for both phages. The CP monomers are shown in rainbow coloring, from the blue $\mathrm{N}$-terminus to the red C-terminus. From the more schematic picture of secondary structure elements (middle), it is obvious that AP205 has N- and C-termini that are located in roughly the same place as the AB loops from MS2. As a result, the $\mathrm{N}$ - and C-termini in AP205 are well exposed on the capsid surface (blue and red, respectively), similarly to the $\mathrm{AB}$ loops (black) in MS2.

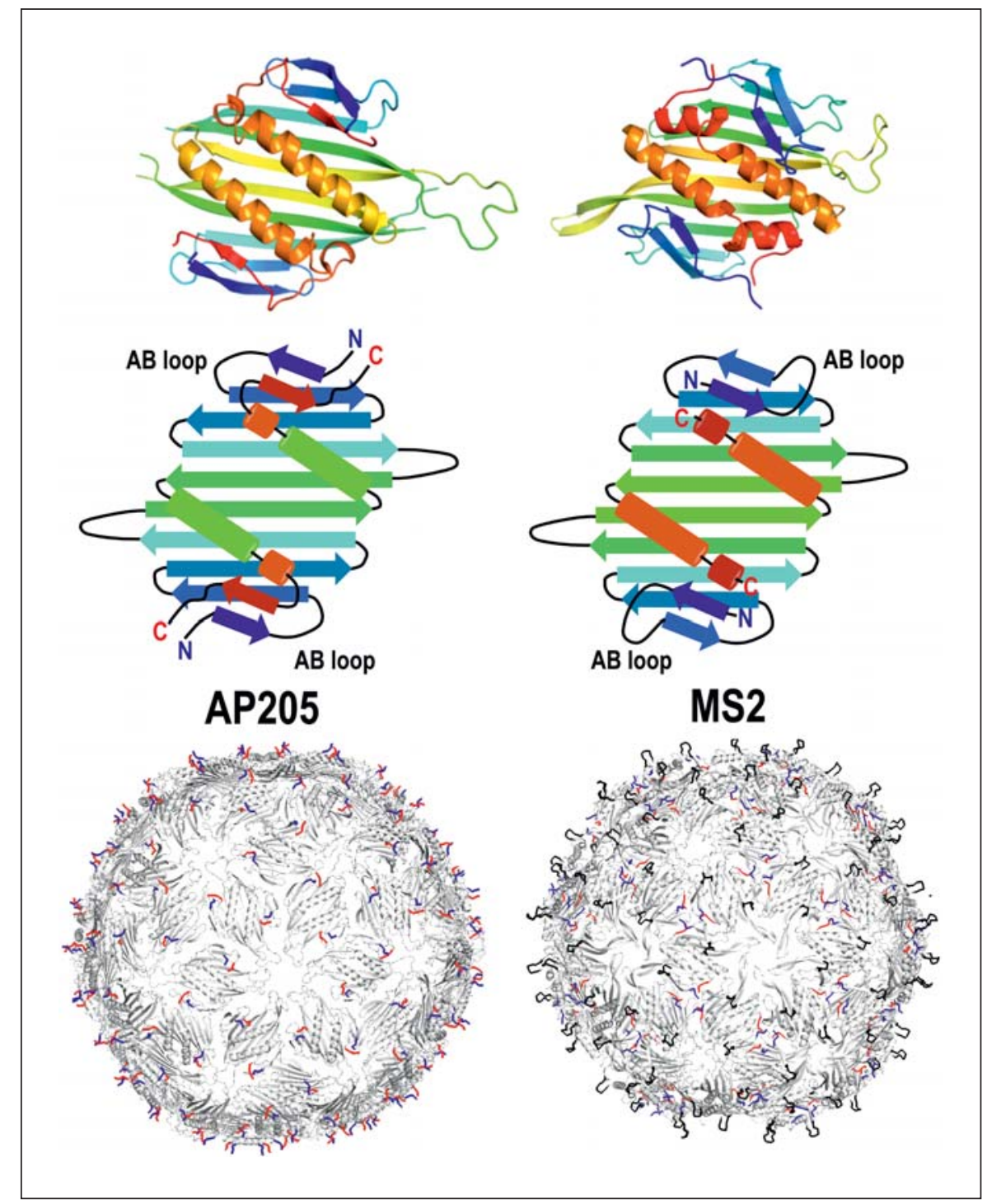

The crystal structure of the $P$. aeruginosa phage PP7 was resolved at a resolution of $3.7 \AA[94,95]$. As in the case of the MS2 and Q $\beta$ CPs, the RNA recognition site on the PP7 CP was determined [96]. Recently, a detailed biophysical study of PP7 virions, including the effects of $\mathrm{pH}$ and salt concentration on the charge transition from netpositive to net-negative, was undertaken [97]. The crystal structure of another Pseudomonas phage, PRR1, was resolved at a resolution of $3.5 \AA$ and exhibited a binding site for a calcium ion close to the quasi-3-fold axis [69].

The crystal structure of a very distant RNA phage, the Caulobacter phage $\varphi \mathrm{CB} 5$, was resolved at $3.6 \AA$, and the structure of a $\varphi$ CB5 VLP was resolved at $2.9 \AA$ [70]. The structures appeared to be nearly identical, with some dif- ferences in the average density of RNA. Unlike in other phages, $\varphi$ CB5 capsids are significantly stabilized by calcium ions, similarly to some plant viruses [98]. Disassembly of these capsids occurs when the calcium ions are chelated with EDTA and/or there is a reduction in the surrounding salt concentration. Another unique feature of $\varphi \mathrm{CB} 5$ is the involvement of RNA bases in the stabilization of its interdimer contacts [70].

Recently, the crystal structure of a phage AP205 dimer was solved at a resolution of $1.7 \AA$ and then fitted into a 6.6- $\AA$ resolution cryo-EM map [99]. The structure of the AP205 CP dimer can be regarded as a circular permutant relative to the structures of MS2 and other family members (fig. 3). This feature is made possible by the fact that 
the $\mathrm{N}$-terminus of one monomer in the dimer is in close proximity to the $\mathrm{C}$-terminus of the other monomer. Compared to MS2 and other phages with known structures, the AP205 CP is missing one beta strand in its Nterminus, but it has an extra beta strand in its $\mathrm{C}$-terminus. However, when considered from a $3 \mathrm{D}$ perspective, the position of the beta strand is essentially the same in both cases. As a consequence, AP205 has N- and C-termini in the same locations as those occupied by surface-exposed $\mathrm{AB}$ loops in other phage capsids. It is notable that the $\mathrm{N}$ and C-termini in other phages are not well exposed on the surface and are clustered around the quasi-3-fold axes. This explains the previous observations that, in contrast to other phages, the AP205 CP can tolerate long additions at its $\mathrm{N}$ - and $\mathrm{C}$-termini without compromising capsid assembly [67].

In addition to the structures of self-assembled RNA phage capsids, the crystal structures of unassembled mutant CP dimers of MS2 [100] and GA [62] have also been resolved. These structures showed only minor differences in comparison to their self-assembled counterparts. Surprisingly, the MS2 CP sustained a genetic fusion, resulting in a duplicated CP that folded normally and functioned as a translational repressor due to its physical proximity to the $\mathrm{N}$ - and C-termini of the CP [101].

Furthermore, the crystal structure of an icosahedral MS2 capsid that was assembled from covalently joined dimers, or so-called single-chain dimers, was resolved at $4.7 \AA$ [102]. The structure resembled the wild-type (wt) virion except for the intersubunit linker regions, but a fraction of the capsids was unstable in phosphate buffer because of assembly defects [102]. Moreover, the organization of MS2 single-chain dimers into crystals may have resulted in an arrangement of subunits that corresponds to $T=3$ octahedral particles [103]. In this case, the arrangement of dimers is somewhat similar to that in normal $\mathrm{T}=3$ icosahedral particles, except that four FG loops interact near the 4-fold axis of symmetry on an octahedron rather than five FG loops interacting near the 5-fold axis of symmetry on an icosahedron. However, when MS2 CP dimers are not crystallized in the F cubic crystal form, they are assembled into $\mathrm{T}=3$ icosahedral capsids that are indistinguishable from the wt particles [103].

\section{Structural Basis of RNA Recognition}

$\mathrm{X}$-ray crystallography led to a breakthrough in understanding the protein-RNA interactions that occur during translational repression and genome encapsidation. This breakthrough was particularly apparent after the first crystal structure of a complex of recombinant MS2 cap- sids with the 19-nucleotide RNA operator was resolved at $2.7 \AA$ [104-106]. The residues responsible for the proteinRNA interactions were localized by analysis of aa exchanges at positions 45 and 59 [107-109]. Furthermore, numerous other mutations responsible for altering the specificity [110] and efficiency [111] of translational operator complexes were identified. The crystal structures of MS2 VLPs complexed with RNA aptamers, which differ in secondary structure from wt RNA [112-114] or involve the presence of $2^{\prime}$-deoxy-2-aminopurine at the critical -10 position [115], have also been resolved.

Structures of CPs in complex with operator RNA fragments have also been solved for PRR1 [116], PP7 [117], and $\mathrm{Q} \beta$ [118]. The CP dimers formed by the RNA phages studied to date all recognize a stem-loop sequence around the replicase start codon. This CP-RNA interaction serves as a mechanism for translational repression and self-genome recognition during virion assembly. Although the overall binding mode of the stem-loop to CP is similar in all the studied cases, the details are surprisingly different among different viruses. A number of nucleotides form sequence-specific and sequence-unspecific interactions with CPs. For CP recognition, the most important nucleotides are two adenosines, one located in the loop region and another in a stem bulge. In MS2, PP7 and Q $\beta$, these adenosines form quite different interactions with the $\mathrm{CP}$ dimer (fig. 4). It should be noted that we have failed to identify analogous CP-RNA interactions in the more distantly related phages AP205 and $\varphi$ CB5 [K. Tars, unpubl. observations], suggesting that mechanisms of genome recognition and translational repression may differ significantly among distant Leviviridae family members.

Electron cryomicroscopy studies have shown that, in addition to the operator, many other RNA sequences in the MS2 genome are able to bind to the CP dimer [119]. Such studies have allowed 3D visualization of icosahedrally averaged genomic MS2 RNA at a resolution of $9 \AA$ [120]. Recently, direct evidence for packaging signal-mediated assembly of the MS2 phage was presented based on cross-linking studies of peptides and oligonucleotides at the interfaces between the capsid proteins and the genomic RNA of this phage $[121,122]$. Remarkably, the same CP-RNA and maturation protein-RNA interfaces were identified in every viral particle.

\section{The A Protein}

Particles of RNA phages contain a single copy of a maturation protein, also known as the A protein, which binds to genomic RNA and is absolutely necessary for the infectivity of phages by attachment to bacterial pili. Therefore,
Pumpens/Renhofa/Dishlers/Kozlovska/ Ose/Pushko/Tars/Grens/Bachmann 


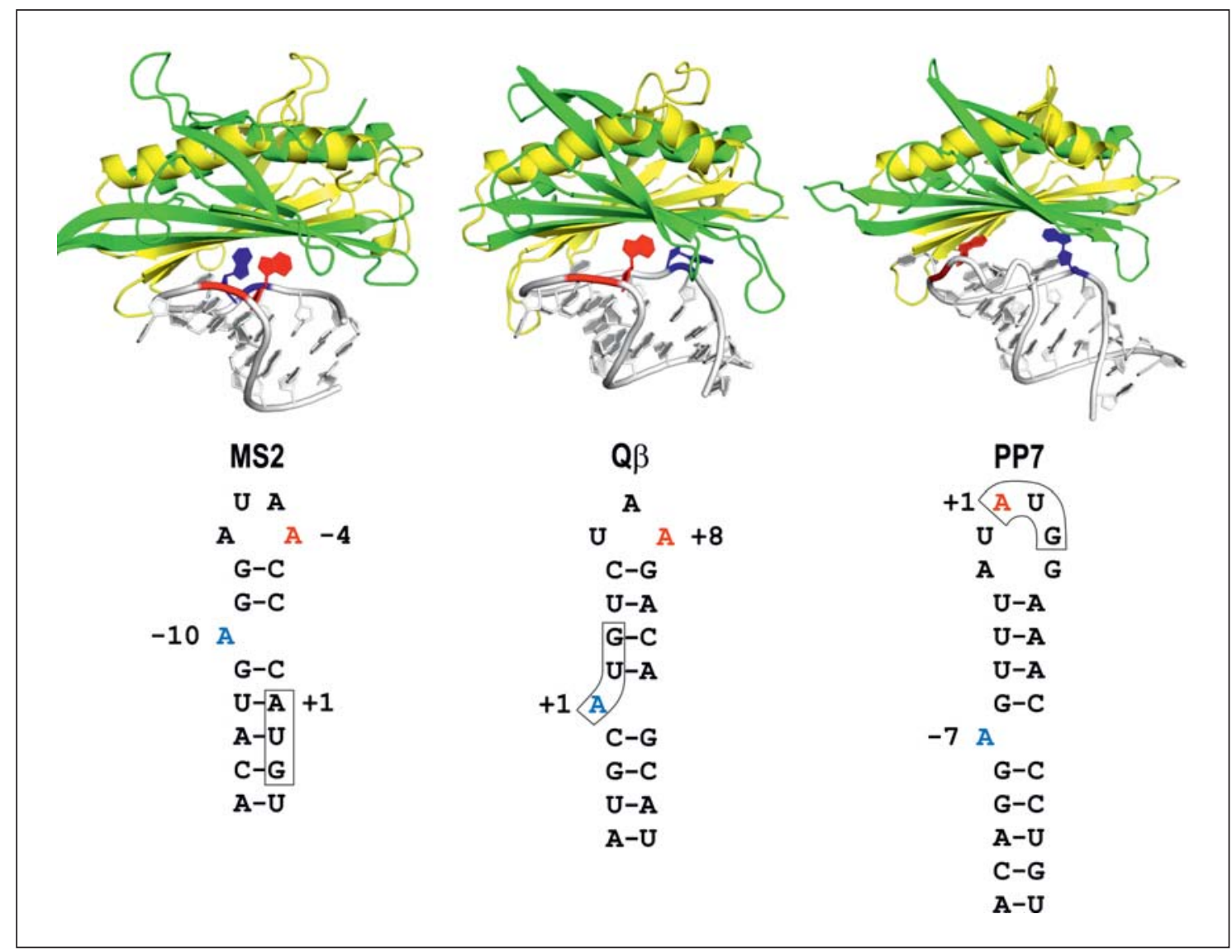

Fig. 4. Different binding modes of operator stem-loop sequences to CP dimers from MS2, Q $\beta$, and PP7. For the operator stem-loop sequences, adenosine, which is required for the binding of loop nucleotides, is shown in red, while bulged adenosine is shown in blue. The replicase gene initiation codon is boxed.

the A protein must be exposed at both the inner and outer surfaces of the CP shell. Because the capsids of ssRNA phages contain holes at the 5 -fold and 3-fold axes of symmetry that are large enough for the diffusion of RNA fragments, it was long believed that the A protein binds in proximity to these axes. However, it was recently shown in cryo-EM studies that the A protein actually replaces a single CP dimer [123, 124]; as such, the virion actually contains $178 \mathrm{CP}$ monomers.

Comparative investigations of MS2 VLPs and virions containing a copy of the A protein by SANS (small-angle neutron scattering) revealed some differences, particularly the presence of 'thin' (preinfection) and 'thick' (postinfection) capsids, which are not seen by crystallography [125]. The role of the A protein during virus assembly may involve the accumulation of tension that is later used to eject the genomic RNA and the A protein into a host cell.

RNA Phage Capsids as Nanotools

\section{Intrinsic Antigenicity and Immunogenicity}

Species-specific virus-neutralizing antibody responses to RNA phages were studied in the late 1960s [126-129]. The MS2 phage was characterized as a T cell-dependent antigen that may also function as a $\mathrm{T}$ cell-independent antigen when used in high doses [130], with high efficacy in inducing T cell response [131]. However, no B cell epitopes have been mapped for virus-neutralizing antibodies on RNA phage capsids. General observations have shown the conformational nature of the B cell epitopes [our unpubl. data]. It was found that only a synthetic MS2 CP peptide spanning from positions 89 to 108 is capable of inhibiting phage neutralization by specific antiserum and of inducing the production of virus-neutralizing antibodies in rabbits [132] and guinea pigs [133]. Chemical conjugation of an $\mathrm{N}$-acetylmuramyl-L-alanyl-D-isoglutamine (MDP) adjuvant to the $89-108$ peptide also markedly increased the induction of virus-neutralizing 
antibodies in rabbits [134]. Although proper CP epitopes have not been mapped, the epitope-recognizing complementarity-determining region (CDR) peptides from a virus-neutralizing monoclonal antibody specific for phages fr, MS2, and GA were described and documented for their capability to neutralize the abovementioned phages [135]. Recently, CDRs from thermostable single-domain anti-MS2 antibodies obtained by the immunization of llamas were sequenced [136].

\section{RNA Phage Coats as a VLP Carrier}

Genetic Fusion as a First Step in the Development of RNA Phage VLP Carriers

Recombinant capsids of fr [137, 138] and MS2 [139] were the first VLP carriers proposed for the presentation of foreign immunological epitopes on their surfaces by genetic fusion. To identify appropriate $\mathrm{CP}$ regions, oligonucleotide linkers encoding short aa sequences and containing convenient restriction sites were inserted into different regions of the fr CP [140]. Remarkably, this work was based on computer predictions of the spatial structure of the fr CP and was conducted before the first crystal structure of an RNA phage, namely that of the homologous MS2 capsid, had been resolved [83-86]. Recombinant fr CPs containing 2- to 12-aa-long additions to their $\mathrm{N}$ - or C-termini or insertions at position 50 in the RNAbinding region were capable of self-assembly, but this was not the case at positions 97-111 in the aA-helix [140]. The majority of other fr CP mutants demonstrated reduced self-assembly capabilities and formed either CP dimers (aa exchanges at residues $2,10,63$, or 129) or both dimer and capsid structures (residue 2 or 69) [141]. The FG loop of the fr CP was also recognized as a potential target for insertions/replacements and was initially modified by a 4 -aa-long deletion [142]. The deletion variant retained the ability to form capsids, although they displayed significantly reduced thermal stability. Furthermore, the 3D structures of the mutant capsids revealed that the modified loops were disordered near the 5-fold axis of symmetry and were too short to interact with each other [142]. Because of the high importance of the FG loop in capsid stability, further development of chimeras based on the implementation of FG loops was not pursued.

Vectors were constructed for the insertion of foreign sequences into codon position 2 of the fr CP-coding sequence in all possible reading frames [137]. When the preS1 epitope DPAFR from hepatitis B virus (HBV) was inserted as a marker at positions 2,10 , and 129 , it appeared in all cases on the particle surface [137]. Attempts to introduce the 40-aa-long V3 loop from the human immunodeficiency virus 1 (HIV-1) gp120 protein into the $\mathrm{N}$-terminus, at positions 10,12 , and 15 , or into the FG loop led to unassembled products [K. Tars, unpubl. data].

Attempts to use the $\mathrm{N}$-terminal $\beta$-hairpin exposed at the surface of the capsid, namely aa residues $15 / 16$, allowed for the production of MS2 capsids bearing a number of different peptide sequences up to 24 aa residues in length [139]. Foreign epitopes exposed on these chimeras were found to be immunogenic in mice [139]. Mutational mapping revealed residues that are responsible for inter- and intramolecular contacts and therefore for the thermal stability of MS2 capsids [143].

The addition of the Flag octapeptide to the N-terminus or its insertion into the $\mathrm{N}$-terminal $\beta$-hairpin of the MS2 $\mathrm{CP}$ prevented self-assembly and proper folding, respectively. However, genetic fusion of the Flag to a duplicated $\mathrm{CP}$-encoding sequence resulted in the synthesis of a protein considerably more tolerant to the structural perturbations and mostly corrected the defects accompanying Flag peptide insertion [144]. The putative protective epitope T1, spanning 24 aa in length and derived from the immunodominant liver stage antigen-1 of the malaria parasite Plasmodium falciparum, was inserted at the tip of the $\mathrm{N}$-terminal $\beta$-hairpin (between positions 15 and 16) of the MS2 CP [145].

fr VLPs have shown unusually high capacities as vectors, particularly when the addition of long segments of hamster polyomavirus VP1 to the N-terminus of the fr CP did not prevent VLP self-assembly [146]. When discovered, these findings markedly enhanced interest in using RNA phage coats as potent vaccine candidates.

However, the relatively low tolerance of fr- and MS2based VLP vectors to long foreign insertions represents a clear limitation of these models. For example, the fr CP failed to form VLPs following the insertion of long HBV preS1 sequences [147]. To overcome this difficulty, Q $\beta$ protein $\mathrm{A} 1$, namely the C-terminal extension of the $\mathrm{Q} \beta$ $\mathrm{CP}$ within the $\mathrm{A} 1$ protein, has been proposed as a site for foreign insertions [148, 149]. Potentially, the 195-aa extension of the $\mathrm{Q} \beta \mathrm{CP}$ could be considered an ideal target for insertions. This region was found to contain elements that typically protrude as spike-like structures on the particle surface. Furthermore, the self-assembly capabilities of capsids with mutually exchanged extensions of the $\mathrm{Q} \beta$ and SP CPs were confirmed experimentally [64]. A following mathematical prediction showed possible colin- 
earity between the $\mathrm{Q} \beta \mathrm{CP}$ extension and the surface-located HBV preS sequence [148]. It is noteworthy that the crystal structure of the read-through domain from the $Q \beta$ A1 protein was recently determined at a resolution of $1.8 \AA$ And revealed a fold that is unique among all proteins found in the protein data bank [150].

$\mathrm{Q} \beta \mathrm{CP}$ proteins with additions at their C-termini failed to form particles in most cases. However, such additions were incorporated into particles in the presence of a wt 'helper' CP to form mixed, or mosaic, particles. Mosaic VLPs differ therefore from chimeric VLPs which are built from identical recombinant CP molecules, without any helper molecules. Such mosaic particles were constructed by either enhancing the level of UGA suppression in the presence of overexpressed suppressor tRNA [151] or by exchanging the UGA stop codon to a GGA sense codon and expressing the extended and helper forms of the $Q \beta$ CP from two separate genes. These genes were located either on the same plasmid or on two separate plasmids with different antibiotic resistance genes. Potential insertion sites were mapped by insertion of the 5-aa preS1 DPAFR model epitope and the 39-aa-long HIV-1 gp120 V3 loop [149]. After enhancing UGA suppression, mosaic particles were detected, but the proportion of A1 to helper CP in these particles dropped from 48 to $14 \%$ as the length of the A1 extension increased [152]. A model insertion of the preS1 epitope DPAFR located on the particle surface produced specific antigenicity and immunogenicity in mice [152]. The antibody response to the preS1 epitope was higher for self-assembled $\mathrm{Q} \beta$-preS1 VLPs than for a nonassembled $\mathrm{Q} \beta$-preS1 variant [153]. When the $\mathrm{Q} \beta \mathrm{CP}$ was modified to carry long HBV preS insertions (full-length preS, preS1, or preS2 alone) instead of the A1 extension, mosaic particles formed that had surface-exposed preS, but regular VLPs did not form without the presence of the $\mathrm{Q} \beta \mathrm{CP}$ as a helper [I. Cielens and R. Renhofa, unpubl. data].

On $\mathrm{Q} \beta \mathrm{CP}$ itself, the residues responsible for RNA recognition have been mapped $[154,155]$. This was helpful for the development of packaging and gene transfer technologies based on the $\mathrm{Q} \beta$ phage model. The ability of the RNA phage CP to package RNA in vivo [156] demonstrated the potential of RNA phages as gene delivery vectors (see Nonvaccine Applications).

Surprisingly, icosahedral Q $\beta$ VLPs have been converted into rods after modification of the FG loop structure [157]. As mentioned above, the appearance of alternate VLP forms of RNA phages was further confirmed by the presence of rod-like structures in the case of the coassembly of phage fr and GA CPs [73].

RNA Phage Capsids as Nanotools
The MS2 phage was found to be capable of accommodating short (pentapeptide) sequences added to the $\mathrm{N}$ terminus of its $\mathrm{CP}$ within viable virions, although not all insertions were genetically stable [158]. Following wellknown peptide display systems based on filamentous phages, a novel peptide display platform on MS2 VLPs was developed and successfully tested, including the identification of conformational epitopes $[159,160]$.

As an experimental example of fusion technology, figure 5 compares RNA phage virions, recombinant VLPs, and chimeric VLPs carrying long foreign insertions by electron microscopy. It is remarkable that the surfaces of some insertion-containing VLPs differ considerably from the surfaces of unmodified VLPs by the appearance of distinct knobs that are presumably formed by the inserted sequences. Besides VLP applications, the phage fr CP was successfully used in its nonassembled variant for the fine mapping of epitopes, primarily of HBV-derived proteins [161-166].

\section{Chemical Coupling to Further Develop VLP \\ Technology}

Chemical coupling of foreign oligopeptides to the surface of VLPs was developed as an alternative method to the genetic fusion of epitope-encoding sequences. Chemical coupling was initially applied to RNA phage $Q \beta$ VLPs in 2002 [167] by using an approach initially developed for another broadly used recombinant VLP, HBc (HBV core antigen) [167, 168]. Model oligopeptides containing a free cysteine residue at the $\mathrm{N}$-terminus were coupled to an exposed lysine residue on the Q $\beta$ VLP surface using the hetero-bifunctional cross-linker maleimidobenzoic acid sulfosuccinimidyl ester. The modified VLPs showed efficient induction of oligopeptide-specific antibodies in mice [167]. This chemical coupling approach initiated the development of a panel of experimental therapeutic vaccines (see early reviews by Bachmann and Dyer [169] and Dyer et al. [170], and a recent review by Bachmann and Jennings [171]). By following the lysine-cysteine oligopeptide coupling methodology, an experimental West Nile virus vaccine was constructed on an AP205 VLP platform [68].

Another chemical coupling approach was developed based on the rational design of modified MS2 VLPs that displayed a reactive thiol on the VLP surface as a result of a T15C substitution in the MS2 CP $[172,173]$. Cysteines are among the most useful functional groups found in proteins as they can bind a variety of metals and react with a large collection of organic reagents, and are therefore obvious targets for protein modification [172]. Two cys- 

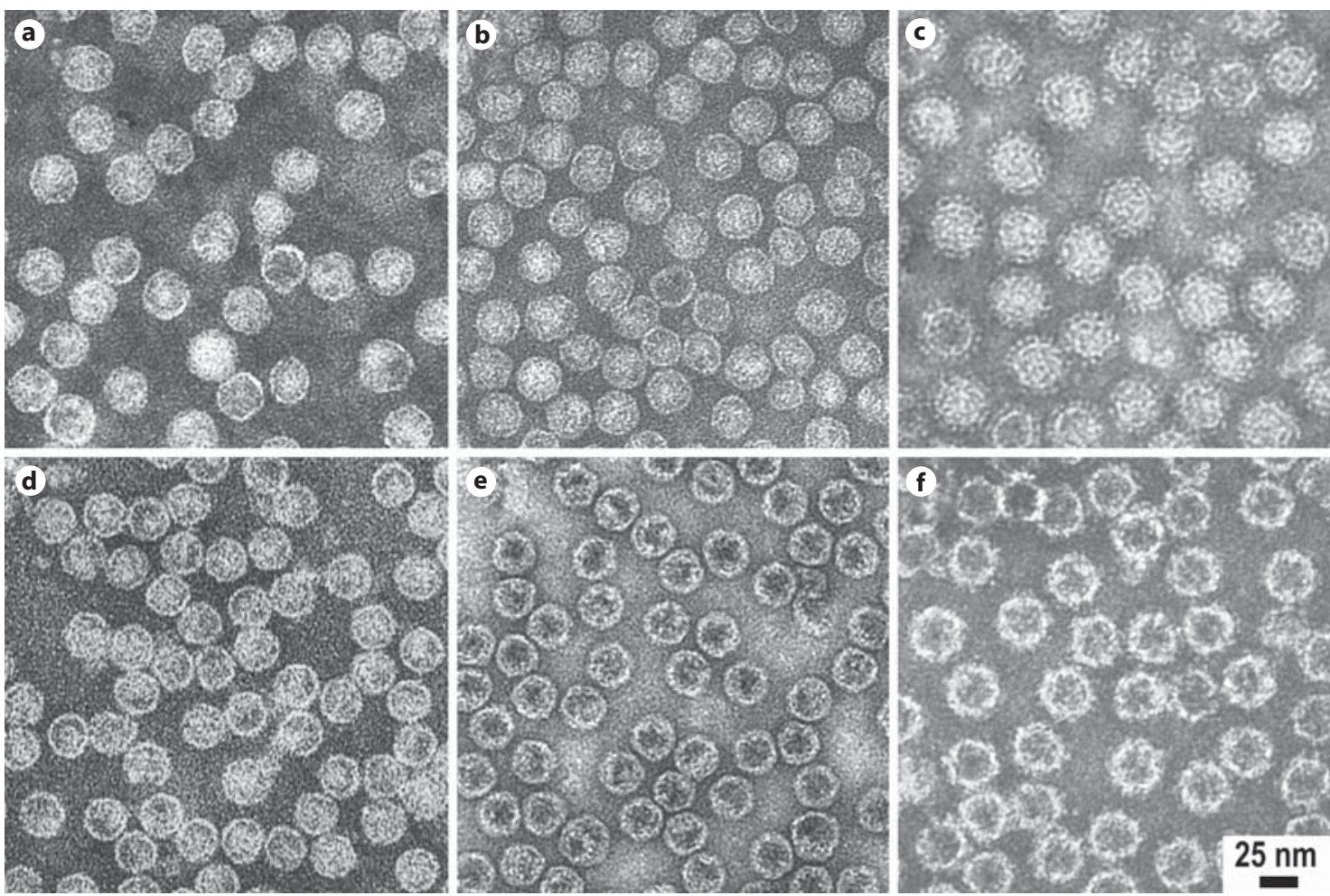

Fig. 5. Electron micrographs of negatively stained AP205 virions (a), recombinant AP205 VLPs (b), chimeric AP205 VLPs carrying 151 aa residues of human interleukin- $1 \beta$ at the C-terminus (c), GA virions (d), recombinant GA VLPs (e), and chimeric GA VLPs carrying a 61-aa-long $\mathrm{Z}_{\mathrm{HER} 2: 342}$ affibody at the C-terminus (f). VLPs are purified from the appropriate gene-expressing E. coli cells. For electron microscopy, the grids with the adsorbed particles were stained with aqueous solutions of $1 \%$ uranyl acetate ( $\mathrm{pH} 4.5)$ or $2 \%$ phosphotungstic acid ( $\mathrm{pH} 7.0)$ and examined with JEM-100C or JEM-1230 electron microscopes (Jeol Ltd., Tokyo, Japan) at 100 $\mathrm{kV}$. Well-ordered knobs are clearly visible on the surfaces of the chimeric VLPs. teine residues that are present in the wt MS2 CP are internally located and therefore relatively unreactive. Thiolated MS2 VLPs were chemically modified with fluorescein-5'-maleimide to create the first fluorescent nanoparticles [173].

Additional functionalization was achieved in a cellfree protein synthesis platform by the production of MS2 and $\mathrm{Q} \beta$ VLPs with surface-exposed methionine analogues (azidohomoalanine and homopropargylglycine) containing azide and alkyne side chains [174]. Such VLPs can be used for one-step, direct conjugation schemes to display multiple ligands of interest. Using such technology, proteins including an antibody fragment and granulocyte-macrophage colony-stimulating factor, as well as nucleic acids and poly(ethylene glycol) chains, were displayed on the VLP surface using $\mathrm{Cu}(\mathrm{I})$ catalyzed click chemistry [174]. Surface functionalization methodology has not only been applied to the VLP surface but also to the interiors of MS2 VLPs by modification of tyrosine residues via a recently developed hetero-Diels-Alder bioconjugation reaction [175].

The preparation of histidine-tagged MS2 VLPs by the introduction of a His 6 linker between CP codons 15 and 16 to simplify the purification of VLP-covered RNAs is another example of VLP surface functionalization [176]. Moreover, a set of advanced $\mathrm{His}_{6}$-tagged $\mathrm{Q} \beta$ VLPs was generated, and their ability to complex metal-derivatized compounds was confirmed $[177,178]$. In parallel, VLP vector capacity for chemical coupling was broadened by the introduction of azide- or alkyne-containing unnatural amino acids, which was achieved by expression of the $\mathrm{Q} \beta \mathrm{CP}$ gene in a methionine auxotrophic strain of $E$. coli [179].

A highly specific approach for the further development of VLP vectors was achieved by the asymmetrization of Q $\beta$ VLPs after the introduction of a single copy of the maturation protein $\mathrm{A} 2$, which allowed the production of VLPs with a single unique modification [180]. 
Recently, a novel plug-and-display system was established for modular RNA phage VLP functionalization via further decoration of VLPs with peptides of interest [181, 182]. The decoration of VLPs is based on the so-called bacterial superglue approach, namely on the ability of a peptide (SpyTag) and a protein (SpyCatcher) to form spontaneous covalent isopeptide bonds between lysine and aspartic acid residues under physiological conditions [183]. The SpyTag and SpyCatcher are split units of the Streptococcus pyogenes fibronectin-binding protein $\mathrm{FbaB}$ and can form a highly stable amide bond by an irreversible reaction that occurs within minutes [184]. The SpyTag or SpyCatcher sequences were genetically fused to the $\mathrm{N}$ - and/or C-terminus of the AP205 CP. After mixing modified AP205 VLPs with the correspondingly linked peptides, the quantitative covalent coupling of the peptides to the VLPs was observed [181, 182].

\section{Stability of VLPS}

Efforts to improve the stability of natural RNA phage VLPs started with the development of a methodology that allowed the screening of bacteria for the synthesis of mutant MS2 CPs with altered assembly properties [185] and the selection of $\mathrm{D} 11 \mathrm{~N}$ variant $\mathrm{CPs}$ that formed virions more stable than the wt CP [186]. The introduction of interdisulfide bonds into the 5-fold axis of symmetry to cross-link MS2 VLPs improved their thermal stability to the level of that seen in Q $\beta$ VLPs, which possess natural intersubunit disulfide bonds [187]. In contrast, cross-linking at the 3-fold axis of symmetry resulted in variant CPs that were unable to self-assemble [187]. The development of an E. coli-based cell-free protein synthesis system opened a direct avenue for studying the role of disulfide bond formation in the stability of mutant MS2 VLPs in comparison to $\mathrm{Q} \beta$ and HBc VLPs [188]. Through the construction of a set of $\mathrm{Q} \beta \mathrm{CP}$ mutants, it was found that disulfide linkages are the most important stabilizing elements in VLPs and that interdimer interactions are less important than intradimer interactions for Q $\beta$ VLP assembly [189].

Elucidation of the thermal stability of foreign epitopecarrying VLPs, such as the chimeric MS2 VLPs formed by single-chain dimers, in comparison to natural disulfide cross-linked PP7 VLPs [190] is of great importance for the further development of RNA phage-based nanotechnology. The genetic fusions of two copies of the MS2 [159], PP7 [191], and GA or Q $\beta$ [I. Cielens and A. Strods, unpubl. data] CPs resulted in a self-assembly-competent single-chain dimer that not only increased thermodynamic stability but also considerably improved tolerance to foreign insertions in the AB-loop. The resultant cor-

RNA Phage Capsids as Nanotools rectly assembled VLPs encapsidated mostly their 'own' CP-encoding mRNAs.

\section{Vaccines and Vaccine Candidates}

Vaccines represent the most advanced field of the RNA phage VLP applications due to the excellent and well-established scaffold properties and structural tolerance to the decoration by foreign immunogenic sequences. Such decoration can be performed both genetically and chemically, and the VLP scaffold may provide foreign epitopes with a strong $\mathrm{T}$ cell response. Moreover, RNA phage VLPs can serve as nanocontainers that can encapsulate specific adjuvants, such as immunostimulatory oligodeoxynucleotides or CpGs, as TLR9 ligands [192]. RNA phage VLPs can also be packaged with singlestranded or double-stranded RNA fragments as TLR7 and TLR3 ligands, respectively [193]. Moreover, recombinant RNA phage VLPs contain encapsulated bacterial RNA, which may act as an adjuvant. Reviews on vaccine applications include articles discussing RNA phage VLPs among other VLP candidates [82, 169-171, 194-202] and articles focused either on RNA phage VLPs in general [203] or on the use of specific RNA phage species, such as MS2 VLPs, as vaccines [204].

\section{Genetic Fusions}

Table 1 contains a detailed list of the vaccine candidates that have been constructed from RNA phage VLPs using genetic fusion methodology. First, the success of an experimental human papilloma virus (HPV) vaccine based on PP7 single-chain-dimer VLPs [191, 205-209] developed in preclinical studies [210] must be mentioned. A similar HPV vaccine candidate was constructed on MS2 single-chain-dimer VLPs and tested in preclinical studies [210, 211]. Both PP7 and MS2 VLP-based vaccines were immunogenic, but the MS2-L2 VLPs induced a broader HPV-neutralizing antibody response. This is likely because of the structural context of L2 display on the VLPs, since L2 was displayed on the AB-loop of the PP7 CP, but at the N-terminus of the MS2 CP [191]. A review on HPV vaccine candidates, including RNA phage VLP-based vaccines, was recently published [212]. A malaria vaccine based on MS2 VLPs has also been reported as very promising $[213,214]$. As to the selection of optimal VLP carriers for such purposes, AP205 VLPs have demonstrated a high capacity and tolerance to foreign insertions [67]. Moreover, the AP205 VLPs represent good candidates for the construction of mosaic VLPs [215]. 
Table 1. Vaccines and vaccine candidates constructed on RNA phage VLPs and viable virions by genetic fusion methodology

\begin{tabular}{|c|c|c|c|c|c|}
\hline Vaccine target & Source of epitope & $\begin{array}{l}\text { Epitope } \\
\text { length, } \\
\mathrm{aa}^{1}\end{array}$ & $\begin{array}{l}\text { Position of } \\
\text { insertion or } \\
\text { addition }\end{array}$ & Comments & References \\
\hline \multirow{5}{*}{$\begin{array}{l}\text { AP205 } \\
\text { Acquired } \\
\text { immunodeficiency: } \\
\text { human } \\
\text { immunodeficiency } \\
\text { virus (HIV) }\end{array}$} & & & \multirow{3}{*}{ C-terminus } & & \multirow{3}{*}{$\begin{array}{l}\text { Cielens and } \\
\text { Renhofa, unpubl. } \\
\text { data }\end{array}$} \\
\hline & $\begin{array}{l}\text { Coreceptor CCR5, ECL2 loops: } \\
\text { mini-loop } \\
\text { CRSQKEGLHYTC and full-length } \\
\text { loop } \\
\text { CRSQK...QTLKC } \\
\end{array}$ & 12,33 & & $\begin{array}{l}\text { VLPs carrying mini-loops are formed with GTAGGGSG, } \\
\text { but not with GSG linker. VLPs carrying full-length loops } \\
\text { are formed with both linkers }\end{array}$ & \\
\hline & $\begin{array}{l}\text { Coreceptor CXCR4, mini-loop: } \\
\text { CNVSEADDRYIC }\end{array}$ & 12 & & $\begin{array}{l}\text { VLPs carrying mini-loops are formed with GTAGGGSG, } \\
\text { but not with GSG linker }\end{array}$ & \\
\hline & Coreceptor CXCR4, aa 1-39 & 39 & N-terminus & The epitope is definitely displayed on the VLP surface & 67 \\
\hline & $\begin{array}{l}\text { Nef protein, aa } 66-100 \text { and } \\
132-151\end{array}$ & 55 & C-terminus & The Nef T cell epitopes are displayed on the VLP surface & \\
\hline \multirow[t]{2}{*}{$\begin{array}{l}\text { Autoimmune } \\
\text { arthritis }\end{array}$} & Interleukin-1 $\beta$, human & $17 \mathrm{kDa}$ & \multirow[t]{2}{*}{ C-terminus } & Chimeric VLPs display knobs on the surface (fig. 5) & $\begin{array}{l}\text { Jansons et al., } \\
\text { unpubl. data }\end{array}$ \\
\hline & $\begin{array}{l}\text { Interleukin- } 1 \alpha \text {, murine } \\
\text { Interleukin- } 1 \beta \text {, murine and human }\end{array}$ & $\begin{array}{l}157,152 \\
154\end{array}$ & & $\begin{array}{l}\text { Mosaic particles are formed by: (i) suppression of } \\
\text { C-terminal amber or opal codons or (ii) coexpression of } \\
\text { the chimeric gene with the helper CP gene. The GSG or } \\
\text { GSGG linkers were used }\end{array}$ & $\begin{array}{l}\text { Cielens and } \\
\text { Renhofa, unpubl. } \\
\text { data }\end{array}$ \\
\hline Cancer, prostate & $\begin{array}{l}\text { Gonadotropin releasing hormone } \\
(\mathrm{GnRH}) \text {, aa } 1-10\end{array}$ & 10 & $\begin{array}{l}\text { N-terminus, } \\
\text { C-terminus }\end{array}$ & $\begin{array}{l}\text { The VLPs carrying C-terminal fusion induce a strong } \\
\text { antibody response that inhibits GnRH function in vivo }\end{array}$ & 67 \\
\hline Chikungunya virus & $\begin{array}{l}\text { Glycoprotein E1, the virus- } \\
\text { neutralizing domain III (DIII); } \\
\text { glycoprotein E2, full-length, } \\
\text { domain A, domain B, domains } \\
\text { A+B }\end{array}$ & $\begin{array}{l}84,361 \\
131,60 \\
298\end{array}$ & C-terminus & $\begin{array}{l}\text { Mosaic particles formed by suppression of the C-terminal } \\
\text { amber codon. The GSG linker was used in all cases }\end{array}$ & $\begin{array}{l}\text { Cielens and } \\
\text { Renhofa, unpubl. } \\
\text { data }\end{array}$ \\
\hline \multirow[t]{2}{*}{$\mathrm{HBV}$} & preS1, aa $21-47$ & 27 & N-terminus & $\begin{array}{l}\text { The SGTAGGGSGS linker was more preferable for the } \\
\text { outcome than the SGG linker }\end{array}$ & \\
\hline & preS1, aa $21-47,20-58,20-119$ & $\begin{array}{l}27,39 \\
100\end{array}$ & C-terminus & The GTAGGGSG linker was used & \\
\hline Hepatitis $\mathrm{C}$ virus & $\begin{array}{l}\text { E2 protein, genotype } 1 \alpha, \text { HVR } \\
\text { sequence, aa } 384-411 \text {; a } \\
\text { 'consensus' HVR sequence }\end{array}$ & 28,31 & N-terminus & The SGTAGGGSGS linker was used in both cases & \\
\hline Hypertension & Angiotensin II, aa 1-8 & 8 & $\begin{array}{l}\text { N-terminus, } \\
\text { C-terminus }\end{array}$ & $\begin{array}{l}\text { Both variants display angiotensin II epitope on the VLP } \\
\text { surface }\end{array}$ & 67 \\
\hline Influenza virus & $\begin{array}{l}\text { M2e protein, } \mathrm{N} \text {-terminal } \\
\text { ectodomain, consensus sequence, } \\
\text { aa } 2-24\end{array}$ & 23 & N-terminus & $\begin{array}{l}\text { Strong M2-specific antibody response was achieved upon } \\
\text { immunization in mice: protection of } 100 \% \text { of mice from a } \\
\text { lethal influenza infection }\end{array}$ & 67,295 \\
\hline $\begin{array}{l}\text { Lymphocytic } \\
\text { choriomeningitis } \\
\text { virus }\end{array}$ & $\begin{array}{l}\text { Glycoprotein, } \\
\text { peptide p33: } \\
\text { KAVYNFATM }\end{array}$ & 9 & C-terminus & $\begin{array}{l}\text { Chimeric VLPs were formed also when different linkers } \\
\text { and another epitope variant KAVYNFATMA have been } \\
\text { used }\end{array}$ & $\begin{array}{l}\text { Cielens and } \\
\text { Renhofa, unpubl. } \\
\text { data }\end{array}$ \\
\hline \multirow[t]{2}{*}{ Obesity } & Ghrelin, aa 24-31: GSSFLSPE & 8 & & $\begin{array}{l}\text { The SGTAGGGSGS linker was more preferable for the } \\
\text { outcome than the SGG linker }\end{array}$ & \\
\hline & $\begin{array}{l}\text { Gastric inhibitory peptide (GIP), } \\
\text { aa } 1-15 \text { of mature GIP ( } 42 \mathrm{aa}) \text { : } \\
\text { YAEGTFISDYSIAMD }\end{array}$ & 15 & & & \\
\hline Salmonella typhi & $\begin{array}{l}\text { Outer membrane protein, D2 } \\
\text { peptide, aa } 266-280\end{array}$ & 15 & $\begin{array}{l}\text { N-terminus, } \\
\text { C-terminus }\end{array}$ & The epitope is displayed on the VLP surface & 67 \\
\hline West Nile virus & $\begin{array}{l}\text { Glycoprotein E, the virus- } \\
\text { neutralizing domain III (DIII), aa } \\
296-406\end{array}$ & 111 & C-terminus & $\begin{array}{l}\text { Mosaic particles. Immunization of mice resulted in the } \\
\text { induction of IgG2 isotype anti-DIII antibodies }\end{array}$ & 215 \\
\hline \multicolumn{6}{|l|}{ fr } \\
\hline $\begin{array}{l}\text { Hamster } \\
\text { polyomavirus }\end{array}$ & $\begin{array}{l}\text { VP1, aa } 364-384,351-374 \\
351-384,333-384\end{array}$ & $\begin{array}{l}21,24,34 \\
52\end{array}$ & N-terminus & Induction of anti-VP1 antibodies in rabbits and mice & 146 \\
\hline
\end{tabular}


Table 1 (continued)

\begin{tabular}{|c|c|c|c|c|c|}
\hline Vaccine target & Source of epitope & $\begin{array}{l}\text { Epitope } \\
\text { length, } \\
\text { aa }^{1}\end{array}$ & $\begin{array}{l}\text { Position of } \\
\text { insertion or } \\
\text { addition }\end{array}$ & Comments & References \\
\hline \multicolumn{6}{|l|}{ GA } \\
\hline \multirow[t]{4}{*}{ HIV } & $\begin{array}{l}\text { Coreceptor CCR5, ECL1 loop } \\
\text { YAAAQWDFGNTMCQ }\end{array}$ & 14 & FG loop & $\begin{array}{l}\text { A shorter insertion without Cys residue } \\
\text { GYAAAQWDFGNTG did not result in the self-assembled } \\
\text { VLPs }\end{array}$ & $\begin{array}{l}\text { Strods and Renhofa, } \\
\text { unpubl. data }\end{array}$ \\
\hline & $\begin{array}{l}\text { Coreceptor CCR5, ECL2a loop } \\
\text { QKEGLHYTG }\end{array}$ & 9 & AB loop, aa $14 / 15$ & & \multirow{6}{*}{$\begin{array}{l}\text { Cielens and } \\
\text { Renhofa, unpubl. } \\
\text { data }\end{array}$} \\
\hline & $\begin{array}{l}\text { Coreceptor CCR5, } \\
\text { N-terminus, } \\
\text { aa } 1-27 \\
\text { aa } 1-31\end{array}$ & 27,31 & $\begin{array}{l}\text { N-terminus of the } \\
\text { second CP copy }\end{array}$ & $\begin{array}{l}\text { Mosaic particles with the GA CP as a helper were formed } \\
\text { in both cases }\end{array}$ & \\
\hline & Coreceptor CXCR4, aa 1-40 & 40 & N-terminus & $\begin{array}{l}\text { Four variants with different linkers and surrounding } \\
\text { sequences formed VLPs }\end{array}$ & \\
\hline \multirow[t]{2}{*}{ Influenza virus } & $\begin{array}{l}\text { M2e protein, } \mathrm{N} \text {-terminal } \\
\text { ectodomain } \\
\text { consensus sequence, aa } 2-24 \text { with } \\
\text { C-terminally added } \mathrm{G} \text { residue }\end{array}$ & 24 & $\begin{array}{l}\text { N-terminus, } \\
\text { C-terminus }\end{array}$ & $\begin{array}{l}\text { The GSGS (GSRS) and GSG linkers were used for } \\
\text { N-terminal and C-terminal insertions, respectively }\end{array}$ & \\
\hline & $\begin{array}{l}\text { M2e protein, } \mathrm{N} \text {-terminal } \\
\text { ectodomain } \\
\text { consensus sequence, aa } 2-24 \text { with } \\
\text { C-terminally added G residue }\end{array}$ & 24 & $\begin{array}{l}\text { N-terminus of the } \\
\text { first CP copy of the } \\
\mathrm{CP} \text { single-chain } \\
\text { dimer }\end{array}$ & The GSG linker was used & \\
\hline S. typhi & $\begin{array}{l}\text { Outer membrane protein, D2 } \\
\text { peptide, aa } 266-280\end{array}$ & 15 & N-terminus & & \\
\hline \multicolumn{6}{|l|}{ MS2 } \\
\hline Cancer, ovarian & $\begin{array}{l}\text { A peptide mimicking the cancer- } \\
\text { associated antigen } 125 \text { (CA125/ } \\
\text { MUC16) }\end{array}$ & 10 & $\begin{array}{l}\text { AB loop of the } \mathrm{CP} \\
\text { single-chain dimer, } \\
\text { aa ' } 15 / 14 \text { ' }\end{array}$ & $\begin{array}{l}\text { The MS2-DISGTNTSRA VLPs induced murine antibodies } \\
\text { that cross-reacted with CA125 from ovarian cancer cells } \\
\text { Preoperative ovarian cancer patient plasma was assessed } \\
\text { for anti-DISGTNTSRA }\end{array}$ & 282 \\
\hline Cholesterol lowering & $\begin{array}{l}\text { Proprotein convertase subtilisin/ } \\
\text { kexin type } 9 \text { (PCSK9), aa } 153-163 \text {, } \\
188-200,208-222,368-381\end{array}$ & $\begin{array}{l}11,13,17 \\
14\end{array}$ & $\begin{array}{l}\mathrm{N} \text {-terminus of the } \\
\mathrm{CP} \text { single-chain } \\
\text { dimer }\end{array}$ & $\begin{array}{l}\text { There were not as dramatic reductions in total cholesterol } \\
\text { in mice immunized with recombinant MS2-PCSK9 VLPs, } \\
\text { in comparison to chimeric Q } \beta \text { VLPs (table 2) }\end{array}$ & 296 \\
\hline $\begin{array}{l}\text { Foot and mouth } \\
\text { disease virus } \\
\text { (FMDV) }\end{array}$ & $\begin{array}{l}\text { VP1, FMDV O/ } \\
\text { OZK, aa } 141-160\end{array}$ & 20 & AB loop & $\begin{array}{l}\text { The effective immune response in mice and protection of } \\
\text { guinea pigs and swine against FMDV were achieved }\end{array}$ & 297 \\
\hline \multirow[t]{2}{*}{ HIV } & gp120 protein, V3 loop & 10 & $\begin{array}{l}\text { AB loop of the } \mathrm{CP} \\
\text { single-chain dimer, } \\
\text { aa ' } 15 / 14 \text { ' }\end{array}$ & $\begin{array}{l}\text { The V3 insertion disrupted self-assembly, but was tolerated } \\
\text { by the CP fusion into the single-chain dimer. High } \\
\text { immunogenicity in mice. The ability to pack their own } \\
\text { mRNA was demonstrated }\end{array}$ & $139,159,298$ \\
\hline & Coreceptor CCR5, ECL2 loop & 10 & & $\begin{array}{l}\text { The ECL2 insertion disrupted self-assembly, but was } \\
\text { tolerated by the CP fusion into the single-chain dimer. } \\
\text { High immunogenicity in mice. Ability to pack their own } \\
\text { mRNA }\end{array}$ & \\
\hline \multirow[t]{2}{*}{$\mathrm{HPV}$} & $\begin{array}{l}\mathrm{L} 1 \text { protein } \\
\mathrm{L} 2 \text { protein }\end{array}$ & $\begin{array}{l}20 \\
20\end{array}$ & $\begin{array}{l}\text { AB loop, } \\
\text { aa ' } 15 / 14 \text { ' }\end{array}$ & & 139,298 \\
\hline & $\begin{array}{l}\text { L2 protein of HPV } 16 \text {, } \\
\text { HPV } 18, \text { HPV } 31 \\
\text { aa } 17-31\end{array}$ & 15 & $\begin{array}{l}\text { N-terminus and } A B \\
\text { loop of the } C P \\
\text { single-chain dimer }\end{array}$ & $\begin{array}{l}\text { Two different epitopes were displayed on the same particle } \\
\text { The strong protection of mice from genital infection with } \\
\text { HPV pseudoviruses representing } 11 \text { diverse HPV types was } \\
\text { demonstrated. Preclinical studies are ongoing }\end{array}$ & $209-211$ \\
\hline \multirow[t]{2}{*}{ Influenza virus } & $\begin{array}{l}\text { Hemagglutinin, epitope } \\
\text { YPYDVPDYA }\end{array}$ & 9 & $\begin{array}{l}\text { AB loop, } \\
\text { aa ' } 15 / 14 \text { ' }\end{array}$ & & 139,298 \\
\hline & $\begin{array}{l}\text { M2e protein, conserved epitope } \\
\text { EVETPIRNE }\end{array}$ & 9 & $\begin{array}{l}\text { AB loop of the CP } \\
\text { single-chain dimer, } \\
\text { aa ' } 15 / 14 \text { ' }\end{array}$ & $\begin{array}{l}\text { The scalable purification protocol for the potential } \\
\text { veterinary vaccine application was elaborated }\end{array}$ & 299 \\
\hline \multirow[t]{3}{*}{ Malaria } & $\begin{array}{l}\text { Plasmodium falciparum, liver stage } \\
\text { antigen-1 (LSA-1), T1 epitope }\end{array}$ & 24 & $\begin{array}{l}\text { AB loop, } \\
\text { aa ' } 15 / 14 \text { ' }\end{array}$ & $\begin{array}{l}\text { The LSA-1-carrying VLPs stimulated a type 1-polarized } \\
\text { response, with significant upregulation of interferon- } \gamma \text {, a } \\
\text { finding which corroborates naturally acquired resistance to } \\
\text { liver stage malaria }\end{array}$ & $139,145,298$ \\
\hline & $\begin{array}{l}\text { P. falciparum, RH5 protein, a } \\
\text { peptide SAIKKPVT } \\
\text { mimicking a linear epitope }\end{array}$ & 8 & \multirow[t]{2}{*}{$\begin{array}{l}\text { AB loop of the CP } \\
\text { single-chain dimer, } \\
\text { aa ' } 15 / 14 \text { ' }\end{array}$} & $\begin{array}{l}\text { The chimeric VLPs elicited antibodies that inhibit parasite } \\
\text { invasion and could form the basis of an effective vaccine } \\
\text { against malaria }\end{array}$ & 213 \\
\hline & $\begin{array}{l}\text { P. falciparum, blood stage antigen } \\
\text { AMA1 (apical membrane } \\
\text { antigen-1) }\end{array}$ & 10 & & $\begin{array}{l}\text { The mimotope identified by VLP-peptide display induced } \\
\text { murine antibodies that cross-reacted with AMA1 }\end{array}$ & 214 \\
\hline
\end{tabular}


Table 1 (continued)

\begin{tabular}{|c|c|c|c|c|c|}
\hline Vaccine target & Source of epitope & $\begin{array}{l}\text { Epitope } \\
\text { length, } \\
\mathrm{aa}^{1}\end{array}$ & $\begin{array}{l}\text { Position of } \\
\text { insertion or } \\
\text { addition }\end{array}$ & Comments & References \\
\hline \multicolumn{6}{|l|}{ PP7 } \\
\hline Flag peptide & DYKDDDDK & 8 & \multirow{3}{*}{$\begin{array}{l}\text { AB loop of the } \mathrm{CP} \\
\text { and of the } \mathrm{CP} \\
\text { single-chain dimer, } \\
\text { aa } 11 / 12\end{array}$} & $\begin{array}{l}\text { The VLPs were highly immunogenic in mice and packaged } \\
\text { their own mRNA }\end{array}$ & 191 \\
\hline HIV & $\begin{array}{l}\text { gp120 protein, V3 loop, a peptide } \\
\text { IQRGPGRAPV }\end{array}$ & 10 & & $\begin{array}{l}\text { The VLPs were highly immunogenic in mice and packaged } \\
\text { their own mRNA }\end{array}$ & 191 \\
\hline \multirow[t]{4}{*}{ HPV } & $\begin{array}{l}\text { L2 protein of HPV16, aa } 17-31 \text { : } \\
\text { QLYKTCKQAGTCPPD }\end{array}$ & 15 & & $\begin{array}{l}\text { The VLPs were highly immunogenic in mice and packaged } \\
\text { their own mRNA. The intravaginal immunization } \\
\text { protected mice from genital infection with HPV } 16 \\
\text { pseudovirions }\end{array}$ & 191,206 \\
\hline & $\begin{array}{l}\text { L2 protein of HPV } 1,5,6,11,16 \\
18,45,58 \text {, aa } 17-31\end{array}$ & 15 & \multirow[t]{2}{*}{$\begin{array}{l}\text { AB loop of the } \mathrm{CP} \\
\text { single-chain dimer, } \\
\text { aa } 11 / 12\end{array}$} & $\begin{array}{l}\text { Mice immunized with the mixture of eight L2 VLPs were } \\
\text { strongly protected from genital challenge with } \\
\text { pseudovirions representing } 8 \text { diverse HPV types. The } \\
\text { anti-L2 antibodies persisted over } 18 \text { months and vaccinated } \\
\text { mice retained protection over a year after immunization. } \\
\text { For the first time in the generation of chimeric VLPs, RNA } \\
\text { was removed from the VLP inside by alkaline treatment, as } \\
\text { it has been performed before on nonchimeric MS2 VLPs } \\
\text { [175] }\end{array}$ & 205,207 \\
\hline & $\begin{array}{l}\text { L2 protein of HPV } 16 \text {, aa } 17-31 \text {, } \\
35-50,51-65,65-79,65-85 \text {, } \\
\text { Consensus } 65-85\end{array}$ & $\begin{array}{l}21 \text { (for } 65 \\
-85 \\
\text { variant) }\end{array}$ & & $\begin{array}{l}\text { Insertion of HPV16 L2 aa } 35-50 \text { and aa } 51-65 \text { was } \\
\text { compatible with VLP assembly, but insertion of aa } 65-79 \\
\text { was not. The VLPs displaying the } 65-85 \text { consensus peptide } \\
\text { of high-risk HPV types induced murine sera that } \\
\text { neutralized heterologous high-risk HPV pseudovirions }\end{array}$ & 208 \\
\hline & $\begin{array}{l}2 \text { protein of HPV1, HPV16, } \\
\text { HPV18, aa } 17-31\end{array}$ & 15 & $\begin{array}{l}\mathrm{N} \text {-terminus and } \mathrm{AB} \\
\text { loop of the } \mathrm{CP} \\
\text { single-chain dimer }\end{array}$ & $\begin{array}{l}\text { Two different epitopes were displayed on the same particle. } \\
\text { The strong protection of mice from genital infection with } \\
\text { HPV pseudoviruses representing } 11 \text { diverse HPV types was } \\
\text { detected }\end{array}$ & 209 \\
\hline Pregnancy & $\begin{array}{l}\text { Human chorionic gonadotropin } \\
\text { (hCG), aa } 39-56,45-55.66-81 \text {, } \\
69-80,111-120,116-125 \\
121-130,131-140,136-145\end{array}$ & $8-16$ & $\begin{array}{l}\text { AB loop of the } \mathrm{CP} \\
\text { single-chain dimer, } \\
\text { aa } 11 / 12\end{array}$ & $\begin{array}{l}\text { Preincubating the hormone with antiserum elicited by } \\
\text { VLPs displaying peptides } 121-130 \text { and } 136-145 \text { failed to } \\
\text { inhibit hCG activity, while sera generated by immunization } \\
\text { with VLPs displaying peptides } 116-125,126-135 \text {, and } \\
131-140 \text { dramatically inhibited uterine weight gain }\end{array}$ & 300 \\
\hline \multicolumn{6}{|l|}{$\mathrm{Q} \beta$} \\
\hline FMDV & $\begin{array}{l}\text { VP1 protein, } \\
\text { G-H loop peptide }\end{array}$ & 14 & $\begin{array}{l}\text { C-terminally added } \\
\text { to the shortened } A 1 \\
\text { protein gene within } \\
\text { the viable } Q \beta \\
\text { genome }\end{array}$ & $\begin{array}{l}\text { A replication-competent hybrid phage that efficiently } \\
\text { displayed the FMDV peptide was achieved. The surface- } \\
\text { localized FMDV VP1 G-H loop cross-reacted with the anti- } \\
\text { FMDV monoclonal antibody SD6 and was found by } \\
\text { electron microscopy to decorate the corners of the Q } \beta \\
\text { icosahedral shell. The hybrid phages induced polyclonal } \\
\text { antibodies in guinea pigs with good affinity to both FMDV } \\
\text { and hybrid Q } \beta \text {-G-H loop }\end{array}$ & 32 \\
\hline \multirow[t]{2}{*}{$\mathrm{HBV}$} & $\begin{array}{l}\text { preS1 epitope: } \\
\text { 31-DPAFR-35 } \\
\text { 31-DPAFRA-36 }\end{array}$ & 5,6 & $\begin{array}{l}\text { Al protein, } \\
\text { C-terminal } \\
\text { extension, aa } 72 / 73 \text {, } \\
\text { after aa } 3,6,13,19 ; \\
\text { as well as instead of } \\
\text { the C-terminal } \\
\text { extension }\end{array}$ & $\begin{array}{l}\text { Mosaic particles were formed by A1-derived chimeras and } \\
\text { Q } \beta \text { CP helper via: (i) suppression of leaky UGA stop codon } \\
\text { of the CP gene and (ii) simultaneous expression of CP } \\
\text { helper and A1-derived genes obtained after the changing of } \\
\text { CP-terminating UGA to strong UAA stop codon or sense } \\
\text { GGA codon, respectively. The proportion of A1-extended } \\
\text { to short CP in mosaic particles varied from } 48 \text { to } 14 \% \text { after } \\
\text { increase of the length of A1 extension. The preS1 epitope } \\
\text { ensured specific immunogenicity in mice }\end{array}$ & $148,149,152$ \\
\hline & $\begin{array}{l}\text { Full-length preS1 and preS2; } \\
\text { preS1, aa } 20-47,20-58 \text {, or } 31-58\end{array}$ & $28-163$ & $\begin{array}{l}\text { Al protein, } \\
\text { C-terminal } \\
\text { extension, aa } 18 \text { or } \\
\text { after leaky } \\
\text { termination codon } \\
\text { instead of the } \\
\text { C-terminal } \\
\text { extension }\end{array}$ & $\begin{array}{l}\text { Mosaic particles were formed by: (i) suppression of } \\
\text { terminal amber or opal codons or (ii) coexpression of the } \\
\text { chimeric gene with the CP helper gene. In the second case, } \\
\text { it was necessary to place the chimeric gene first within the } \\
\text { plasmid }\end{array}$ & $\begin{array}{l}\text { Cielens and } \\
\text { Renhofa, unpubl. } \\
\text { data }\end{array}$ \\
\hline HIV & $\begin{array}{l}\text { gp120 protein, V3 loop, aa } \\
299-337\end{array}$ & 39 & $\begin{array}{l}\text { Al protein, } \\
\text { C-terminal } \\
\text { extension, aa } 72 / 73 \text {; } \\
\text { after aa } 19 \text {; instead } \\
\text { of the C-terminal } \\
\text { extension }\end{array}$ & Mosaic particles were formed & 148,149 \\
\hline
\end{tabular}

The data are given in alphabetical order of the (i) phage model and (ii) vaccine target for the same phage model.

${ }^{1}$ When a precise number of aa residues is difficult to assess, the size of the epitopes is expressed in $\mathrm{kDa}$. 
Table 2. Vaccines and vaccine candidates constructed on RNA phage VLPs by chemical coupling methodology

\begin{tabular}{llll}
\hline Vaccine target $\quad$ Source of epitope & $\begin{array}{l}\text { Epitope Coupling site } \\
\text { length, } \\
\mathrm{aa}^{1}\end{array}$ & Comments \\
\hline
\end{tabular}

\section{AP205}

Asthma/allergy IL-5, murine
$33 \mathrm{kDa}$

The VLP display led to the efficient breaking of selfgenetically fused to the tolerance

$\mathrm{N}$-terminus and/or

C-terminus

\begin{tabular}{llll}
\hline Cancer & $\begin{array}{l}\text { Human telomerase reverse transcriptase, the } \\
\text { mutant Telo epitope biotin-GAHIVMV- } \\
\text { DAYKPTREARPALLTSRLRFIPK }\end{array}$ & $\begin{array}{l}\text { SpyCatcher genetically } \\
\text { fused to the }\end{array}$ \\
& $\begin{array}{l}\text { N-terminus } \\
\text { DAYR }\end{array}$
\end{tabular}

SpyCatcher is a genetically encoded protein designed to spontaneously form a covalent bond to its peptidepartner SpyTag carrying desired epitope

\begin{tabular}{|c|c|c|c|c|c|}
\hline & $\begin{array}{l}\text { Human epidermal growth factor receptor } \\
\text { (EGFR) from glioblastoma, fusion junction } \\
\text { epitope LEEKKGNYVVTDHGAHIVMV- } \\
\text { DAYKPTK-biotin }\end{array}$ & 27 & & & \\
\hline & $\begin{array}{l}\text { Murine proteins involved in cancer (CTLA- } \\
\text { 4, PD-L1, Survivin and HER2) }\end{array}$ & $\begin{array}{l}\text { kDa: } 15 \\
273083\end{array}$ & \multirow{2}{*}{$\begin{array}{l}\text { SpyTag or SpyCatcher: } \\
\text { genetically fused to the } \\
\text { N-terminus and/or } \\
\text { C-terminus }\end{array}$} & \multirow[t]{2}{*}{$\begin{array}{l}\text { The VLP display led to the efficient breaking of self- } \\
\text { tolerance }\end{array}$} & \multirow[t]{2}{*}{182} \\
\hline $\begin{array}{l}\text { Cardiovascular } \\
\text { disease }\end{array}$ & PCSK9, murine & $84 \mathrm{kDa}$ & & & \\
\hline $\begin{array}{l}\text { Human } \\
\text { immunodeficiency } \\
\text { virus (HIV) }\end{array}$ & $\begin{array}{l}\text { Six peptides covering the } \alpha \text {-helical regions of } \\
\text { gp } 41: 3-13,3-17,3-20,3-24, \mathrm{P} 1, \mathrm{P} 8 \\
\text { provided with a C-terminal Cys residue }\end{array}$ & $\begin{array}{l}12,16,19 \\
23,40,66\end{array}$ & Lysine residues & $\begin{array}{l}\text { The gp } 41 \text { peptides were coupled to AP205 VLPs } \\
\text { through a bifunctional cross-linker SMPH. The } \\
\text { chimeric VLPs elicited high titers of gp } 41 \text {-specific } \\
\text { antibodies. 1, 2, or } 3 \text { peptide copies were coupled to } \\
\text { each AP205 subunit }\end{array}$ & 301 \\
\hline $\begin{array}{l}\text { Lymphocytic } \\
\text { choriomeningitis } \\
\text { virus (LCMV) }\end{array}$ & $\begin{array}{l}\text { Glycoprotein, the } \mathrm{p} 33 \text { peptide } \\
\text { KAVYNFATM }\end{array}$ & 9 & & $\begin{array}{l}\text { Chimeric VLPs were packaged by CpG and induced } \\
\text { effective CTL response in mice }\end{array}$ & 224 \\
\hline \multirow[t]{2}{*}{ Malaria } & $\begin{array}{l}\text { P. falciparum, membrane protein } 1 \\
\text { (PfEMP1) containing the Complex lysine } \\
\text { and cysteine-rich inter-domain region } \\
\text { (CIDR) } \\
\text { P. falciparum, Pfs } 25 \text { protein }\end{array}$ & $27 \mathrm{kDa}$ & $\begin{array}{l}\text { SpyCatcher genetically } \\
\text { fused to the } \\
\text { N-terminus }\end{array}$ & $\begin{array}{l}\text { A pair of SpyTag and SpyCatcher as a functional unit } \\
\text { were used (see above). Injecting SpyCatcher-VLPs } \\
\text { decorated with a malarial antigen efficiently induced } \\
\text { antibody responses after only a single immunization }\end{array}$ & 181 \\
\hline & $\begin{array}{l}\text { P. falciparum, circumsporozoite protein } \\
\text { (CSP), CIDR, VAR2CSA, and Pfs } 25 \text { proteins }\end{array}$ & $\begin{array}{l}\text { kDa: } 53 \\
32,118 \\
40\end{array}$ & $\begin{array}{l}\text { SpyTag or SpyCatcher: } \\
\text { to the N-terminus } \\
\text { and/or C-terminus }\end{array}$ & $\begin{array}{l}\text { The Pfs } 25 \text { and VAR2CSA vaccines showed efficacy } \\
\text { that is comparable with the efficacy of the best existing } \\
\text { analogues }\end{array}$ & 182 \\
\hline Salmonella typhi & $\begin{array}{l}\text { Outer membrane protein, D2 peptide, } \\
\text { aa 266-280: TSNGSNPSTSYGFAN with } \\
\text { N-terminal CGG linker }\end{array}$ & 15 & Lysine residues & $\begin{array}{l}\text { The vaccine preparations of 13,56,94, 142, and } 293 \\
\text { peptides per VLP were used. A phenomenon of carrier } \\
\text { induced epitopic suppression could be overcome by } \\
\text { high coupling densities, repeated injections and/or } \\
\text { higher doses of conjugate vaccine }\end{array}$ & 230 \\
\hline Tuberculosis & Mycobacterium tuberculosis, Ag85A protein & $48 \mathrm{kDa}$ & $\begin{array}{l}\text { SpyTag or SpyCatcher: } \\
\text { genetically fused to the } \\
\text { N-terminus and/or } \\
\text { C-terminus }\end{array}$ & & 182 \\
\hline $\begin{array}{l}\text { West Nile virus } \\
(\text { WNV) }\end{array}$ & $\begin{array}{l}\text { Glycoprotein E, the virus-neutralizing } \\
\text { domain III (DIII), aa } 582-696 \text { of the WNV } \\
\text { polyprotein precursor }\end{array}$ & 115 & Lysine residues & $\begin{array}{l}\text { Domain III was engineered to comprise a } \mathrm{His}_{6} \text { tag and } \\
\text { a Cys-containing linker at its C-terminus. The } \\
\text { antibodies induced in mice were able to neutralize } \\
\text { virus in vitro and provided partial protection from a } \\
\text { challenge with a lethal dose of WNV }\end{array}$ & 68 \\
\hline $\begin{array}{l}\text { Q } \beta \\
\text { Acquired } \\
\text { immunodeficiency: } \\
\text { feline } \\
\text { immunodeficiency } \\
\text { virus (FIV) }\end{array}$ & $\begin{array}{l}\text { Transmembrane (TM) glycoprotein, a } \\
\text { peptide containing tryptophan-rich motif, aa } \\
767-786 \text { : LQKWEDWVGWIGNIPQYLKG }\end{array}$ & 20 & Lysine residues & $\begin{array}{l}\text { Immunized cats developed antibodies that reacted } \\
\text { with the epitope, but failed to recognize whole FIV. } \\
\text { The coupling efficiency was never higher than } 20 \%\end{array}$ & 302 \\
\hline $\begin{array}{l}\text { Acquired } \\
\text { immunodeficiency: } \\
\text { HIV }\end{array}$ & $\begin{array}{l}\text { Coreceptor CCR5, N-terminal ECL domain, } \\
\text { circularized }\end{array}$ & 20 & & $\begin{array}{l}\text { Immunized mice and rabbits generated antibodies that } \\
\text { recognized native CCR } 5 \text { and inhibited entry of } \\
\text { pseudotype viruses bearing envelope glycoproteins } \\
\text { from diverse primary strains in vitro }\end{array}$ & 303,304 \\
\hline
\end{tabular}


Table 2 (continued)

\begin{tabular}{|c|c|c|c|c|c|}
\hline Vaccine target & Source of epitope & $\begin{array}{l}\text { Epitope } \\
\text { length, } \\
\mathrm{aa}^{1}\end{array}$ & Coupling site & Comments & References \\
\hline $\begin{array}{l}\text { Acquired } \\
\text { immunodeficiency: } \\
\text { HIV/simian } \\
\text { immunodeficiency } \\
\text { virus (SIV) }\end{array}$ & $\begin{array}{l}\text { Coreceptor CCR5, macaque, ECL1, } \\
\text { N-terminal aa } \\
\text { MDYQVSSPTYDIDYYTSEPC; ECL2, a } \\
\text { cyclic peptide, aa } 168-177 \\
\text { DRSQREGLHYTG linked through an DG } \\
\text { dipeptide spacer }\end{array}$ & 20,10 & \multirow[t]{3}{*}{ Lysine residues } & $\begin{array}{l}\text { Immunization of mice and rats induced anti-CCR } 5 \\
\text { antibodies that recognized native CCR } 5 \text { and inhibited } \\
\text { SIV infection in vitro. Equal amounts of both } \\
\text { constructs were mixed to formulate the vaccine that } \\
\text { was protective in macaques. The coupling efficiency } \\
\text { reached } 90 \text { EC1 or } 270 \text { ECL2 peptides per particle }\end{array}$ & 305,306 \\
\hline Allergy & $\begin{array}{l}\text { Cysteine protease, the major fecal allergen of } \\
\text { the house dust mite } D \text {. pteronyssinus, Der p } 1 \\
\text { peptide, aa } 117 \text { - 133: } \\
\text { CGIYPPNANKIREALAQTHSA }\end{array}$ & 21 & & $\begin{array}{l}\text { The vaccine was administered without adjuvants and } \\
\text { found safe and immunogenic in humans after } \\
\text { evaluation of different doses and routes of } \\
\text { immunization }\end{array}$ & 307 \\
\hline Allergy, cat & $\begin{array}{l}\text { Fel d } 1 \text { protein, major cat allergen, a covalent } \\
\text { dimer of chain } 2 \text { and chain } 1 \text { of Fel d } 1 \\
\text { spaced by a } 15 \text { aa-linker (GGGGS) } \times 3 \text { and } \\
\text { added to the coding sequence for } \\
\text { LEHHHHHHGGC at the C- terminus }\end{array}$ & $23 \mathrm{kDa}$ & & $\begin{array}{l}\text { A single vaccination by } \mathrm{Q} \beta \text {-Fel d } 1 \text { was sufficient to } \\
\text { induce protection against type I allergic reactions in } \\
\text { mice. Moreover, Q } \beta \text {-Fel d } 1 \text { did not induce } \\
\text { degranulation of basophils derived from human } \\
\text { volunteers with cat allergies. The coupling density was } \\
40 \% \text {, or } 70 \text { covalent Fel d } 1 \text { dimers per VLP }\end{array}$ & 308 \\
\hline \multirow[t]{2}{*}{$\begin{array}{l}\text { Allergy, } \\
\text { rhinoconjunctivitis, } \\
\text { rhinitis }\end{array}$} & $\begin{array}{l}\text { A-type CpG (QbG10) was encapsulated as a } \\
\text { TLR9 ligand. Mixed with house dust mite } \\
\text { (HDM) extract }\end{array}$ & - & \multirow[t]{3}{*}{ No coupling } & $\begin{array}{l}\text { A phase I study. All patients achieved practically } \\
\text { complete alleviation of allergy symptoms after } 10 \\
\text { weeks of immunotherapy }\end{array}$ & 217 \\
\hline & $\begin{array}{l}\text { CYT003-QbG10: CpG QbG10 was } \\
\text { encapsulated }\end{array}$ & - & & $\begin{array}{l}\text { A phase IIb study. Treatment with high-dose CYT003- } \\
\text { QbG10 improved disease symptoms. The QbG10 } \\
\text { content was approximately } 20 \% \text { of the total mass, } \\
\text { corresponding to } \sim 60 \text { molecules per VLP }\end{array}$ & 218,219 \\
\hline Allergy, asthma & CYT003-QbG10 & - & & A successful phase IIb study & 220,221 \\
\hline $\begin{array}{l}\text { Allergy, asthma and } \\
\text { rhinitis }\end{array}$ & $\begin{array}{l}\text { Two IgE peptides, different loops of the C3 } \\
\text { domain: ADSNPRGVSAYLSRPSPGGC and } \\
\text { YQCRVTHPHLPRALMRS }\end{array}$ & 20,16 & \multirow[t]{7}{*}{ Lysine residues } & $\begin{array}{l}\text { The vaccine induced high titers of anti-human IgE } \\
\text { antibodies by preclinical studies in mice }\end{array}$ & 309 \\
\hline Allergy to red meat & $\begin{array}{l}\text { a-1, 3-galactosyl transferase, Gala3LN } \\
\text { epitope. For conjugation, } \alpha \text {-Gal trisaccharide } \\
\text { and glucose were converted to their } \\
\text { respective alkyne derivatives. Each alkyne } \\
\text { was attached by a two-step procedure in } \\
\text { which the protein nanoparticle was first } \\
\text { acylated with an azide-terminated } \\
\text { N-hydroxysuccinimide ester and then } \\
\text { addressed by copper-catalyzed azide-alkyne } \\
\text { cycloaddition }\end{array}$ & $\begin{array}{l}\text { Carbohy- } \\
\text { drates are } \\
\text { conjugat- } \\
\text { ed }\end{array}$ & & $\begin{array}{l}\text { Search for the presence of } \alpha \text {-Gal-containing epitopes } \\
\text { in the saliva of Amblyomma sculptum. Bites from the } \\
\text { A. sculptum tick may be associated with the allergic } \\
\text { reactions to red meat in Brazil }\end{array}$ & 310 \\
\hline \multirow[t]{3}{*}{ Alzheimer disease } & A $\beta$ peptide (1-9)-GGC: DAEFRHDSGGGC & 12 & & $\begin{array}{l}\mathrm{Q} \beta \text {-A } \beta \text { VLPs elicited anti-A } \beta \text { antibody responses at } \\
\text { low doses and without the use of adjuvants }\end{array}$ & 311 \\
\hline & $\begin{array}{l}A \beta \text { peptide: } N \text {-terminal } A \beta(1-9) \text { or } \\
\text { C-terminal } A \beta(28-40)\end{array}$ & 12,16 & & $\begin{array}{l}\text { Both of these immunogens produced significant } \\
\text { antibody titers without use of additional adjuvants and } \\
\text { reduced A } \beta \text { levels when tissues were examined } 8 \\
\text { months after the first inoculation }\end{array}$ & 312 \\
\hline & $\begin{array}{l}\text { CAD106 vaccine: } A \beta \text { peptide } 1-6 \text { DAEFRH } \\
\text { plus a GGC spacer }\end{array}$ & 9 & & $\begin{array}{l}\text { CAD106 avoided activation of A } \beta \text {-specific T cells and } \\
\text { was efficacious in reducing the amyloid accumulation } \\
\text { in transgenic mice without evidence of unwanted side } \\
\text { effects and is currently being tested in patients in a } \\
\text { phase II study. Each VLP contained } \sim 350-550 \mathrm{~A} \beta \\
\text { peptides }\end{array}$ & 313 \\
\hline Atherosclerosis & $\begin{array}{l}\text { IL-1 } \alpha \text {, full length, containing aa linker at } \\
\text { C-terminus }\end{array}$ & $17 \mathrm{kDa}$ & & $\begin{array}{l}\text { Immunization of mice reduced both the inflammatory } \\
\text { reaction in the plaque as well as plaque progression }\end{array}$ & 314 \\
\hline $\begin{array}{l}\text { Autoimmune } \\
\text { arthritis }\end{array}$ & $\begin{array}{l}\text { IL- } 1 \alpha \text {, murine, aa } 117-270 \text { of IL- } 1 \alpha \\
\text { precursor } \\
\text { IL- } 1 \beta \text {, murine, aa } 119-269 \text { of IL- } 1 \beta \\
\text { precursor, both provided with aa linkers at } \\
\text { C-termini }\end{array}$ & $17 \mathrm{kDa}$ & & $\begin{array}{l}\text { Immunization of mice elicited a rapid and long-lasting } \\
\text { autoantibody response. In the collagen-induced } \\
\text { arthritis model, both vaccines strongly protected mice } \\
\text { from inflammation and degradation of bone and } \\
\text { cartilage. In the T and B cell-independent collagen Ab } \\
\text { transfer model, immunization with the IL- } 1 \beta \text { vaccine } \\
\text { strongly protected from arthritis, whereas } \\
\text { immunization with the IL-1 } 1 \alpha \text { vaccine had no effect. } \\
\text { The coupling efficiency was about } 20 \% \text { in the case of } \\
\text { IL- } 1 \alpha \text { and } 28 \% \text { in the case of IL- } 1 \beta \text {, or } 36 \text { molecules of } \\
\text { IL- } 1 \alpha \text { or } 50 \text { molecules of IL- } 1 \beta \text { per VLP }\end{array}$ & 315,316 \\
\hline
\end{tabular}


Table 2 (continued)

\begin{tabular}{ll}
\hline Vaccine target & Source of epitope \\
\hline $\begin{array}{l}\text { Autoimmune } \\
\text { arthritis, } \\
\text { encephalomyelitis } \\
\text { and myocarditis }\end{array}$ & $\begin{array}{l}\text { IL-17, murine, aa 26-158, with a C-terminal } \\
\text { linker GGGGGC }\end{array}$ \\
\hline $\begin{array}{l}\text { Cancer, induction of } \\
\text { antitumor antibodies }\end{array}$ & $\begin{array}{l}\text { Tumor-associated carbohydrate antigens } \\
\text { (TACAs): monomeric Tn antigen (GalNAc- } \\
\text { a-O-Ser/Thr) that is overexpressed on the } \\
\text { surface of a variety of cancer cells including } \\
\text { breast, colon, and prostate cancer, and is } \\
\text { involved in aggressive growth and lymphatic } \\
\text { metastasis of cancers }\end{array}$ \\
$\begin{array}{l}\text { TACAs: ganglioside GM2, a tetrasaccharide, } \\
\text { overexpressed in a wide range of tumor cells }\end{array}$ \\
\end{tabular}

Epitope

length,

Coupling site

Comments

References

$\mathrm{aa}^{1}$

$32 \mathrm{kDa}$

Immunization induced high levels of autoantibodies

$317-319$

in mice and was effective in ameliorating disease symptoms in animal models of autoimmunity. The coupling efficiency was about $10 \%$, or 18 IL-17 homodimers per VLP

$\begin{array}{lll}\begin{array}{l}\text { Carbohy- } \\ \text { drates are } \\ \text { conjugat- }\end{array} & \text { Lysine residues and } & \begin{array}{l}\text { The antibodies generated in mice were highly selective } \\ \text { toward Tn antigens and reacted strongly with the } \\ \text { native Tn antigens on human leukemia cells }\end{array}\end{array}$
conjugatnative Tn antigens on human leukemia cells

GM2 immobilized on VLPs through a thiourea linker 236 elicited high titers of IgG antibodies that recognized GM2-positive tumor cells and effectively induced cell lysis through complement mediated cytotoxicity

Cholesterol lowering Proprotein convertase subtilisin/kexin type $9 \quad 9,11,17 \quad$ Lysine residues Vaccination of mice and macaques led to significant 296 (PCSK9), human, aa 68-76, 153-163, reductions in total cholesterol, free cholesterol, phospholipids, and triglycerides (table 1) $207-223$

Chronic TNF- $\alpha$, murine, aa $80-235$ of the TM form, 156,20

inflammatory aa 4-23 peptide: disorders: CGGSSQNSSDKPVAHVVANHQVE

rheumatoid arthritis,

psoriasis, Crohn's

disease

Chronic

IL-1 $\beta$, murine, rhesus monkey and human

153

inflammatory

illnesses: type 2

two muteins: mIL- $1 \beta$ (D143K), mIL-1 $\beta$

(D143K) with strongly reduced inflammatory

diabetes mellitus activity

\begin{tabular}{lll}
\hline Eosinophilia & $\begin{array}{l}\text { Recombinant IL-5; recombinant eotaxin, } \\
\text { both murine }\end{array}$ & $\begin{array}{l}17 \text { and } \\
8 \mathrm{kDa}\end{array}$
\end{tabular}

\begin{tabular}{|c|c|c|}
\hline $\begin{array}{l}\text { Hen egg lysozyme } \\
\text { (HEL), as a model } \\
\text { for overcoming } \\
\text { self-tolerance }\end{array}$ & Full-length & 129 \\
\hline
\end{tabular}

\begin{tabular}{lll}
\hline HPV & L2 protein, N-terminal HPV16 peptides: aa & $19,23,21$, \\
& $34-52,49-71,65-85,108-120$, consensus & 13 \\
& $65-85$ peptide
\end{tabular}

\begin{tabular}{ll}
\hline Hypertension & $\begin{array}{l}\text { CYT006-AngQb vaccine: angiotensin II- } \\
\text { derived peptide CGGDRVYIHPF where } \\
\text { CGG is a linker }\end{array}$ \\
\hline
\end{tabular}


Table 2 (continued)

\begin{tabular}{|c|c|c|c|c|c|}
\hline Vaccine target & Source of epitope & $\begin{array}{l}\text { Epitope } \\
\text { length, } \\
\mathrm{aa}^{1}\end{array}$ & Coupling site & Comments & References \\
\hline $\begin{array}{l}\text { Hypertension, } \\
\text { diabetic } \\
\text { nephropathy, } \\
\text { atherosclerosis }\end{array}$ & $\begin{array}{l}\text { ATRQ } \beta-001 \text { vaccine: ATR- } 001 \text { peptide } \\
\text { CAFHYESQ corresponding to an epitope of } \\
\text { the ECL } 2 \text { of human AT1R, a G-protein } \\
\text { coupling receptor }\end{array}$ & 8 & Lysine residues & $\begin{array}{l}\text { A successful preclinical trial: the ATRQ } \beta \text { - } 001 \text { vaccine } \\
\text { decreased the blood pressure of Ang II-induced } \\
\text { hypertensive mice and spontaneously hypertensive } \\
\text { rats. The vaccine provided a promising method to } \\
\text { treat diabetic nephropathy in rats and atherosclerosis } \\
\text { in mice }\end{array}$ & $327-329$ \\
\hline
\end{tabular}

\begin{tabular}{|c|c|c|}
\hline $\begin{array}{l}\text { Inflammatory } \\
\text { hyperalgesia: } \\
\text { potential long-term } \\
\text { therapy for chronic } \\
\text { pain }\end{array}$ & $\begin{array}{l}\text { Nerve growth factor (NGF), murine, aa } \\
19-241 \text { of pro-NGF } \beta \text { and an additional } 9 \text { aa } \\
\text { extension at the C terminus comprising a } \\
\text { His }_{6} \text { tag and GGC sequence }\end{array}$ & 223 \\
\hline Influenza virus & M2 protein, $\mathrm{N}$-terminal extracellular domain & 23 \\
\hline
\end{tabular}

Hemagglutinin, globular head domain (gH1), 281 A/California/07/2009 (H1N1) strain, aa

49-325 and C-terminal extension GGGCG

\begin{tabular}{|c|c|c|}
\hline LCMV & $\begin{array}{l}\text { Glycoprotein, peptides: p33, KAVYNFATM; } \\
\text { p13, GLNGPDIYKGVYQFKSVEFD; p33- } \\
\text { gp61, CKSLKAVYNFATMGLNGPDIYKG- } \\
\text { VYQFKSVEF with a GGC linker added to } \\
\text { the C-terminus }\end{array}$ & $9,20,32$ \\
\hline Malaria & $\begin{array}{l}\text { Plasmodium falciparum, CSP, an almost } \\
\text { full-length CSP consisting of } 19 \text { NANP and } 3 \\
\text { NVDP repeats and the majority of the N- } \\
\text { and C-terminal regions (residues } 26_{\mathrm{Tyr}^{-}} \\
127_{\text {Asp }} \text { linked to } 207_{\mathrm{Pro}}-383_{\mathrm{Ser}} \text { ) }\end{array}$ & $45 \mathrm{kDa}$ \\
\hline Melanoma & $\begin{array}{l}\text { Mel-QbG10 vaccine: Melan-A/Mart-1 A27L } \\
\text { variant peptide CGHGHSYTTAEELAGI- } \\
\text { GILTV Packaging with QbG10 CpG: } \\
\text { GGGGGGGGGGGACGATCGT- } \\
\text { CGGGGGGGGGG }\end{array}$ & 20 \\
\hline
\end{tabular}

Nicotine addiction CYT002-Nic-Qb vaccine, or

NIC002 (formerly known as Nicotine-Q $\beta$ or

Nic- $Q \beta)$ : nicotine was covalently coupled to

$Q \beta$ VLPs via a succinimate linker

\begin{tabular}{ll}
\hline Obesity & Q $\beta$-GIP vaccine: gastric inhibitory peptide \\
(GIP, also known as glucose-dependent & insulinotropic polypeptide), aa $1-15$ \\
& YAEGTFISDYSIAMD of mature GIP (42 aa) \\
& with C-terminally added linker GC
\end{tabular}

Osteoporosis Q 3 -TRANCE/RANKL vaccine: TNF-related 159 activation-induced cytokine (TRANCE), also known as receptor activator of NF- $\kappa B$ ligand

(RANKL), aa 158-316 (extracellular

domain) of the mature form of murine

TRANCE/RANKL with a Cys-linker and

$\mathrm{His}_{6}$ tag

\begin{tabular}{|c|c|}
\hline $\begin{array}{l}\text { Vaccination with NGFQ } \beta \text { substantially reduced } \\
\text { hyperalgesia in collagen-induced arthritis or } \\
\text { postinjection of zymosan A, two models of } \\
\text { inflammatory pain in mice. The coupling efficiency } \\
\text { was about } 60 \text { NGF molecules per VLP }\end{array}$ & 330 \\
\hline $\begin{array}{l}\text { Intranasal immunization of mice with Q } \beta \text { VLP-M2 } \\
\text { resulted in strong M2-specific antibody responses as } \\
\text { well as antiviral protection }\end{array}$ & 226 \\
\hline $\begin{array}{l}\text { Preclinical studies of a set of gH1 variants from } \\
\text { mouse-adapted virus and } 2009 \mathrm{H} 1 \mathrm{~N} 1 \text { virus were } \\
\text { performed. During phase I trial, nonadjuvanted } \\
\text { gH1-Q } \beta \text { showed similar antibody mediated } \\
\text { immunogenicity and a comparable safety profile in } \\
\text { healthy humans to commercially available vaccines }\end{array}$ & $331-333$ \\
\hline
\end{tabular}

of the CTL induction by the CpG packaging

By immunization of mice, the Q $\beta$-CSP induced higher 334 anti-NANP repeat titers, higher levels of cytophilic IgG2b/c antibodies and a trend towards higher protection against transgenic parasite challenge as compared to soluble CSP formulated in the same adjuvant. The coupling efficiency was about $12-25 \%$, or an average of $\sim 30$ CSP molecules per VLP

Promising results were obtained by phase I and IIa clinical trials on stage II-IV melanoma patients. The coupling density reached 160 peptide copies per VLP

Preclinical studies in mice and successful phase I and II clinical trials were performed. Stable vaccine formulations enabling storage were developed. An experimental comparison to a NIC-CRM vaccine by Pfizer was achieved. The coupling density was about 3.25 nicotine molecules per CP monomer, or 585 nicotine molecules per VLP

Immunization of mice with $Q \beta-$ GIP vaccine induced 339 high titers of specific antibodies and efficiently reduced body weight gain in animals fed a high-fat diet. Moreover, increased weight loss was observed in obese mice vaccinated with VLP-GIP. The coupling density was about 1.6-2.2 GIP molecules per CP monomer

Immunization of mice with Q $\beta$-TRANCE/RANKL VLPs overcame the natural tolerance of the immune system toward self-proteins and produced high levels of specific antibodies without the addition of any adjuvant. Serum antibodies of immunized mice neutralized TRANCE/RANKL activity in vitro and were highly active in preventing bone loss in a mouse model of osteoporosis. The coupling density was about $14 \%$, indicating that about one of seven CP monomers was covalently attached to a peptide. As TRANCE/

RANKL forms a trimer, 25 C-TRANCE trimers were displayed per VLP 
Table 2 (continued)

\begin{tabular}{lllll}
\hline Vaccine target & Source of epitope & $\begin{array}{l}\text { Epitope } \\
\text { length, } \\
\text { a }^{1}\end{array}$ & Coupling site & Comments \\
\hline Salmonella typhi & $\begin{array}{l}\text { Outer membrane protein, D2 peptide, a } \\
\text { 266-280 TSNGSNPSTSYGAN with } \\
\text { N-terminal CGG linker }\end{array}$ & 18 & Lysine residues & $\begin{array}{l}\text { The vaccine preparations of 13, 56, 94, 142, and 293 } \\
\text { peptides per VLP were used. It was shown that the } \\
\text { phenomenon of carrier-induced epitopic suppression } \\
\text { could be overcome by high coupling densities, } \\
\text { repeated injections and/or higher doses of conjugate } \\
\text { vaccine (see above for AP205) }\end{array}$ \\
\hline
\end{tabular}

The order of data presentation is the same as in table 1 .

${ }^{1}$ When a precise number of aa residues is difficult to assess, the size of the epitopes is expressed in $\mathrm{kDa}$.

\section{Chemical Coupling}

The chemical coupling approach was validated by an impressive line of experimental therapeutic vaccines $[169,171]$. The idea of therapeutic vaccines is based on the assumption that VLP carriers can present surfacedisplayed self-antigens and to augment their ability to overcome the natural tolerance of the immune system toward self-proteins and to induce high levels of specific autoantibodies [216]. Initially, this approach was planned as a method to replace host-specific monoclonal antibodies in the treatment of acute and chronic diseases, starting with noninfectious diseases [169]. Therefore, the transition from passive administration of monoclonal antibodies to active vaccination against self-antigens was a logical step in drug development, focusing on affordable medicines and broader patient acceptance and regulatory compliance. The induction of autoantibodies might be beneficial under certain physiological conditions in order to remove unwanted excess of a particular self-antigen, such as angiotensin in the case of hypertension. Table 2 presents a detailed list of predominantly therapeutic vaccines and demonstrates the validity of this assumption.

We included the well-known $Q \beta$ VLP-based allergy vaccine CYT003-QbG10 that contains an encapsulated CpG sequence, so-called QbG10, in table 2, although it does not carry any attached epitope [217-221]. However, this potentially successful vaccine initially originated from epitope-coupling methodology. Moreover, we included RNA phage VLPs carrying model epitope p33, which is derived from the lymphocytic choriomeningitis virus glycoprotein [222-229], and epitope D2, which is derived from Salmonella [230]. Although these are not actual vaccine candidates, the model epitopes have played a central role in the elucidation of the fine immunological mechanisms that govern responses to chimeric VLPs.

RNA Phage Capsids as Nanotools
The display of small antigens, such as nicotine [231$234]$ or carbohydrate moieties [235, 236], on RNA phage VLP surfaces is a novel approach that enabled the generation of strong immunological responses against nonpeptide antigens and paved the way for the development of experimental vaccines against nicotine addiction and cancer, respectively. We recommend a recent review on novel vaccines constructed on RNA phage VLPs [237] as well as special reviews on vaccines against allergies [238240], Alzheimer disease [241], hypertension [242-244], influenza [245, 246], malaria [247], and nicotine addiction [248-252].

\section{Nonvaccine Applications}

Attention is currently focused on the use of virusbased nanoparticles as potential scaffolds for novel biomaterials and as subjects for nanoscale engineering applications involving exposure to various chemical compounds [253-256].

\section{Drug Delivery by Nanocontainers}

Table 3 summarizes RNA phage VLP-based experimental approaches that could be classified as VLP packaging and targeting methodologies. Historically, the idea of encapsulation/targeting by RNA phage VLPs appeared in the early 1990s, only a few years after the vaccine/epitope display approaches described above. A first attempt at RNA phage nanocontainer-targeted drug delivery involved, first of all, encapsulation of a deglycosylated ricin A chain coupled to an RNA operator stem-loop and decoration of the MS2 VLPs by transferrin [257-259]. Such structures, called 'synthetic virions' by the authors, demonstrated high toxicity to leukemia cells carrying transferrin receptor. A detailed review of these and similar pi- 
Table 3. The RNA phage VLPs as models for nanocontainer packaging and decoration with addressing/targeting/delivery purposes

\begin{tabular}{|c|c|c|c|c|c|}
\hline Interior: packaged by & Exterior: decorated by & Addressed to & Supposed to treat & Comments & Refer \\
\hline \multicolumn{6}{|l|}{ AP205 } \\
\hline $\begin{array}{l}\text { Random E. coli } \mathrm{RNA} \text {, } \\
\text { without any specific } \\
\text { packaging }\end{array}$ & $\begin{array}{l}\text { HBV, full-length preS1, aa } \\
13-119\end{array}$ & $\begin{array}{l}\text { Eukaryotic cell lines HepG2, } \\
\text { Hek293, Jurkat, Namalwa, and } \\
\text { BHK-21 }\end{array}$ & HBV infection & $\begin{array}{l}\text { The uptake took place, but seemed cell } \\
\text { line unspecific and not highly efficient }\end{array}$ & 341 \\
\hline
\end{tabular}

fr

C-terminus of th

Potentially broad

This is a first example of the

Jansons and

applications in

generation of mosaic VLPs carrying

the IgG-binding $\mathrm{Z}$ domain that could

be targeted to antibodies displayed on

Sominskaya,

as a helper

diagnostics

the cell surface and used in diagnostics

GA

GA operator-specified

mRNA in

No decoration

No cell targeting

Broad spectrum of

Packaging of different mRNAs

342

encoding GA coat protein, ENA-78,

and GFP in vivo in yeast S. cerevisiae

HIV-Tat (48-60) or WNV E Human peripheral blood

potential targets

Production of mosaic VLPs that are

packaged by mRNAs encoding IL2 or

GFP was achieved in vivo in yeast $S$.

cerevisiae

\begin{tabular}{|c|c|c|c|}
\hline $\begin{array}{l}\text { MS2 operator-specified } \\
\text { mRNA in vivo }\end{array}$ & No decoration & No cell targeting & $\begin{array}{l}\text { Broad spectrum of } \\
\text { potential targets }\end{array}$ \\
\hline
\end{tabular}

Introduction of single (S87N, K55N, $\mathrm{R} 43 \mathrm{~K})$ and double (S87N + K55N and $\mathrm{S} 87 \mathrm{~N}+\mathrm{R} 43 \mathrm{~K}$ ) aa exchanges into the GA CP allowed self-assembly and packaging of MS2 operator-carrying mRNAs in vivo in yeast $S$. cerevisiae

\begin{tabular}{|c|c|c|c|c|c|}
\hline \multirow[t]{2}{*}{ No specific packaging } & $\begin{array}{l}\mathrm{Z}_{\mathrm{HER} 2: 342} \text { affibody, } 61 \text { aa in } \\
\text { length }\end{array}$ & HER2 receptor on cancer cells & Diagnostics/therapy & $\begin{array}{l}\text { Ability of GA- } Z_{\text {HER2:342 }} \text {-VLPs to } \\
\text { recognize selectively and enter the } \\
\text { HER2 receptor-bearing cells was } \\
\text { demonstrated. Electron microscopy } \\
\text { of this construction is presented in } \\
\text { figure } 5\end{array}$ & \multirow[t]{2}{*}{$\begin{array}{l}\text { Strods and } \\
\text { Renhofa, } \\
\text { unpubl. data }\end{array}$} \\
\hline & $\begin{array}{l}\text { Stromal cell-derived factor } \\
\text { (SDF1), aa } 1-41 \text { and } 1-19\end{array}$ & CXCR4 receptor on leukocytes & Diagnostics/therapy & $\begin{array}{l}\text { Insertions at the N-terminus of the } \\
\text { first or second single-chain dimer } \\
\text { copy were performed. Some members } \\
\text { of the family recognized specific cells }\end{array}$ & \\
\hline
\end{tabular}

MS2

Ricin A coupled to RNA operator; 5-fluorouridine coupled to RNA operator

Transferrin, anti-MS2 antibodies, anti-DF3 antibodies

Antisense

oligodeoxynucleotides

(ODNs) targeted to

human nucleolar protein p120 mRNA

\section{$50-70$ fluorescein}

molecules conjugated to

the interior of VLPs

Fluorescent dye conjugated to the VLP interior

\section{Covalent decoration with} transferrin on the VLP surface
Cells of the immune system; cells

Promyelocytic leukemia cell line Acute myelogenous leukemia

Classical attempt to use RNA operator

257,258 as a carrier of the desired material

The ODNs were synthesized as covalent extensions to the $19 \mathrm{nt}$ long operator sequence

344 
Table 3 (continued)

\begin{tabular}{|c|c|c|c|c|c|}
\hline Interior: packaged by & Exterior: decorated by & Addressed to & Supposed to treat & Comments & References \\
\hline $\begin{array}{l}\text { Coupling of } 180 \\
\text { porphyrins capable of } \\
\text { generating cytotoxic } \\
\text { singlet oxygen upon } \\
\text { illumination }\end{array}$ & $\begin{array}{l}\sim 20 \text { copies of a Jurkat- } \\
\text { specific aptamer }\end{array}$ & Jurkat leukemia T cells & Leukemia & $\begin{array}{l}\text { The doubly modified VLPs were able } \\
\text { to target and kill Jurkat cells selectively } \\
\text { even when mixed with erythrocytes }\end{array}$ & 267 \\
\hline $\begin{array}{l}\text { Nanoparticles, } \\
\text { chemotherapeutic drugs, } \\
\text { siRNA cocktails, and } \\
\text { protein toxins }\end{array}$ & $\begin{array}{l}\text { SP94 peptide that binds } \\
\text { human hepatocellular } \\
\text { carcinoma (HCC) cells }\end{array}$ & Hep3B cells & $\mathrm{HCC}$ & $\begin{array}{l}\text { The targeted VLPs loaded with } \\
\text { doxorubicin, cisplatin, and } \\
\text { 5-fluorouracil selectively killed the } \\
\text { HCC cell line, Hep3B. Encapsidation } \\
\text { of a siRNA cocktail induced growth } \\
\text { arrest and apoptosis of Hep3B cells. } \\
\text { Loading of VLPs with ricin toxin } \\
\text { A-chain killed the entire population of } \\
\text { Hep3B cells }\end{array}$ & 268 \\
\hline
\end{tabular}

\begin{tabular}{|c|c|c|c|c|c|}
\hline $\begin{array}{l}\text { Micro-RNA: pre-miR } \\
146 a\end{array}$ & $\begin{array}{l}\text { Particles conjugated with } \\
\text { HIV-1 Tat }(47-57) \text { peptide }\end{array}$ & Human PBMCs & $\begin{array}{l}\text { Systemic lupus } \\
\text { erythematosus, } \\
\text { osteoclastogenesis }\end{array}$ & $\begin{array}{l}\text { Restoring the loss of miR-146a was } \\
\text { effective in eliminating the production } \\
\text { of autoantibodies }\end{array}$ & $347-349$ \\
\hline $\begin{array}{l}\text { RNA conjugate } \\
\text { encompassing a siRNA } \\
\text { and the operator sequence }\end{array}$ & $\begin{array}{l}\text { Covalent attachment of } \\
\text { human transferrin }\end{array}$ & HeLa cells & $\begin{array}{l}\text { Potentially broad } \\
\text { applications }\end{array}$ & $\begin{array}{l}\text { The VLPs entered cells via receptor- } \\
\text { mediated endocytosis and produced } \\
\text { siRNA effects better than by } \\
\text { traditional lipid transfection route }\end{array}$ & 350 \\
\hline
\end{tabular}

\begin{tabular}{|c|c|c|c|}
\hline Gold nanoparticles & $\begin{array}{l}\text { Alexa Fluor } 488 \text { (AF 488) } \\
\text { labelled DNA strands }\end{array}$ & No cell targeting & $\begin{array}{l}\text { No definite target } \\
\text { disease specified }\end{array}$ \\
\hline
\end{tabular}

The VLP architecture by placing the 351

dye at distances of 3,12 , and $24 \mathrm{bp}$

from the surface of VLPs bearing

10-nm gold nanoparticles allowed the

rapid exploration of many variables

involved in metal-controlled

fluorescence

Porphyrin: loaded with
approximately 250
cationic porphyrins
through a novel assembly
packaging mechanism

Cancer cells targeting

nucleic acid aptamers via

MCF-7 human breast cancer

cells

chemical conjugation

Breast cancer upon
photoactivation

-7 cells incubated with

targeted, porphyrin-loaded virus capsids exhibited cell death. The strategy offered an approach for efficient targeted delivery of

photoactive compounds for sitespecific photodynamic cancer therapy

\begin{tabular}{ll}
\hline $\begin{array}{l}\text { Various reporters to be } \\
\text { used by fluorescence- } \\
\text { based flow cytometry, } \\
\text { confocal microscopy, and } \\
\text { mass cytometry }\end{array}$ & $\begin{array}{l}\text { Antibodies using a rapid } \\
\text { oxidative coupling strategy }\end{array}$ \\
\hline $\begin{array}{l}\text { Long noncoding RNA: } \\
\text { MEG3 RNA }\end{array}$ & $\begin{array}{l}\text { GE11, a dodecapeptide } \\
\text { YHWYGYTPQNVI, ligand } \\
\text { of epidermal growth factor } \\
\text { receptor (EGRF), chemically } \\
\text { coupled }\end{array}$
\end{tabular}

Antibody-capsid conjugates are targeting extracellular receptors on human breast cancer cell lines

Breast cancer

The broad set of conjugates with various reporters on the interior of VLPs may lead to many clinically relevant applications, including drug delivery and in vivo diagnostics

EGFR HCC cell line The targeted delivery was dependent on clathrin-mediated endocytosis and MEG3 RNA suppressed tumor growth mainly via increasing the expression of $\mathrm{p} 53$ and its downstream gene GDF15, but decreasing the expression of MDM2

\begin{tabular}{|c|c|c|c|c|c|}
\hline $\begin{array}{l}\text { LacZ RNA fused to RNA } \\
\text { operator }\end{array}$ & No decoration & No cell targeting & $\begin{array}{l}\text { Potentially broad } \\
\text { applications }\end{array}$ & $\begin{array}{l}\text { This is a classical attempt to ensure } \\
\text { operator-specific packaging in vivo }\end{array}$ & 156 \\
\hline $\begin{array}{l}\text { MS2 operator sequence } \\
\text { linked to the human } \\
\text { growth hormone mRNA } \\
\text { for in vivo packaging in } S . \\
\text { cerevisiae }\end{array}$ & & & $\begin{array}{l}\text { No definite target } \\
\text { disease specified }\end{array}$ & $\begin{array}{l}\text { This is a sort of application belonging } \\
\text { to the 'armored RNA' technology. } \\
\text { Functionality of packaged mRNA was } \\
\text { confirmed by translation of mRNAs } \\
\text { purified from VLPs }\end{array}$ & 74 \\
\hline Taxol & & & $\begin{array}{l}\text { Breast, lung, and } \\
\text { ovarian cancers }\end{array}$ & $\begin{array}{l}\text { Aa exchange N87C on the interior of } \\
\text { VLP allowed use of sulfhydryl groups } \\
\text { for the attachment of taxol, a potent } \\
\text { chemotherapeutic, as a cargo }\end{array}$ & 264 \\
\hline $\begin{array}{l}\text { HIV-1 gag mRNAs }(1544 \\
\text { bases) produced in } S . \\
\text { cerevisiae }\end{array}$ & & & HIV/AIDS: as a vaccine & $\begin{array}{l}\text { The HIV antigen-specific antibody } \\
\text { responses were elicited by } \\
\text { immunization of BALB/C mice }\end{array}$ & 355 \\
\hline $\begin{array}{l}\text { Alkaline phosphatase } \\
\text { tagged with a } 16 \text { aa } \\
\text { peptide }\end{array}$ & & & $\begin{array}{l}\text { No definite target } \\
\text { disease specified }\end{array}$ & $\begin{array}{l}\text { This is a first attempt to encapsulate } \\
\text { enzymes where the encapsulated } \\
\text { enzyme had the same } K(m) \text { value and } \\
\text { a slightly lower } k(\text { cat }) \text { value than the } \\
\text { free enzyme }\end{array}$ & 356 \\
\hline
\end{tabular}


Table 3 (continued)

\begin{tabular}{|c|c|c|c|c|c|}
\hline Interior: packaged by & Exterior: decorated by & Addressed to & Supposed to treat & Comments & References \\
\hline $\begin{array}{l}\text { mRNA joined to } 19-n t \\
\text { operator/aptamer }\end{array}$ & & Macrophages & Prostate cancer & $\begin{array}{l}\text { The packaged mRNA ensured strong } \\
\text { humoral and cellular immune } \\
\text { responses and protected mice as a } \\
\text { therapeutic vaccine against prostate } \\
\text { cancer }\end{array}$ & 357 \\
\hline \multirow[t]{2}{*}{ No specific packaging } & Tumor cell-specific peptides & Tumor cells & Solid tumors & $\begin{array}{l}\text { Three peptides known to target } \\
\text { specific tissues: (i) neuroblastoma and } \\
\text { breast cancer cell lines, (ii) matrix } \\
\text { metalloproteinases, (iii) kidney were } \\
\text { chosen as attachment models }\end{array}$ & 263 \\
\hline & $\begin{array}{l}\text { Conjugation of azide- and } \\
\text { alkyne-containing proteins } \\
\text { (an antibody fragment and } \\
\text { the granulocyte-macrophage } \\
\text { colony stimulating factor), } \\
\text { nucleic acids, and PEG }\end{array}$ & $\begin{array}{l}\text { Broad spectrum of potential } \\
\text { targeting }\end{array}$ & $\begin{array}{l}\text { Tumors and other } \\
\text { possible targets }\end{array}$ & $\begin{array}{l}\text { This is a universal approach based on } \\
\text { the inclusion of surface exposed } \\
\text { methionine analogues } \\
\text { (azidohomoalanine and } \\
\text { homopropargylglycine) containing } \\
\text { azide and alkyne side chains by cell- } \\
\text { free synthesis technology }\end{array}$ & 174 \\
\hline
\end{tabular}

$\mathrm{Q} \beta$

CpG ODNs $\quad \begin{aligned} & \text { With and without specific } \quad \text { Cells of immune system } \\ & \text { addressing }\end{aligned}$
applications

This is a classic example of the ODN

$217-229$ addressing applications as prophylactic and/or therapeutic vaccines

\begin{tabular}{lll}
\hline $\begin{array}{l}\sim 60 \text { Alexa Fluor 568 } \\
\text { fluorophores per VLP }\end{array}$ & Fullerene $\mathrm{C}_{60}$ and PEG & HeLa cell line \\
& & \\
\hline $\begin{array}{l}\text { Metalloporphyrin } \\
\text { derivative for } \\
\text { photodynamic therapy }\end{array}$ & $\begin{array}{l}\text { Glycan ligand for specific } \\
\text { targeting of cells bearing the } \\
\text { CD22 receptor }\end{array}$ & CD22 receptor \\
& &
\end{tabular}

\section{Aptamers embedded in a longer RNA sequence} with the $\mathrm{Q} \beta \mathrm{CP}$ operator

Positively charged synthetic polymer by atom transfer radical polymerization (ATRP) methodology

\section{Proteins: $25-\mathrm{kDa}$}

$\mathrm{N}$-terminal aspartate dipeptidase, peptidase E, $62-\mathrm{kDa}$ firefly luciferase (Luc), a thermostable mutant of Luc

No specific packaging

No decoration No cell targeting

Cancer

This approach overcame the insolubility of $\mathrm{C}_{60}$ in water and opened

the door for the applications in photoactivated tumor therapy

This approach benefited from the presence of the strong targeting

function and the delivery of a high local concentration of singlet oxygengenerating payload

The VLPs ensured the delivery of the $\quad 361,362$ $\begin{array}{ll}\begin{array}{l}\text { Potentially broad } \\ \text { applications in therapy }\end{array} & \begin{array}{l}\text { The VLPs ensured the delivery of the } \\ \text { encapsulated aptamers that were } \\ \text { protected from degradation and }\end{array}\end{array}$ retained ability to bind their smallmolecule ligands

\begin{tabular}{ll} 
& $\begin{array}{l}\text { protected from degradation and } \\
\text { retained ability to bind their small- } \\
\text { molecule ligands }\end{array}$ \\
\hline $\begin{array}{l}\text { Potentially broad } \\
\text { applications in therapy } \\
\text { and imaging } \\
\text { diagnostics }\end{array}$ & $\begin{array}{l}\text { This is a robust method for removing } \\
\text { encapsidated RNA from VLPs and the } \\
\text { use of the empty interior space for } \\
\text { site-specific, 'graft-from' ATRP } \\
\text { reactions }\end{array}$ \\
\hline $\begin{array}{l}\text { No definite target } \\
\text { disease specified }\end{array}$ & $\begin{array}{l}\text { The encapsulated enzymes were } \\
\text { stabilized against thermal degradation, } \\
\text { protease attack, and hydrophobic } \\
\text { adsorption }\end{array}$
\end{tabular}

\begin{tabular}{|c|c|c|c|c|}
\hline $\begin{array}{l}\text { Copper }(\mathrm{I}) \text {-catalyzed azide- } \\
\text { alkyne cycloaddition } \\
\text { reaction }\end{array}$ & Variety of cells & $\begin{array}{l}\text { Potentially broad } \\
\text { applications }\end{array}$ & $\begin{array}{l}\text { Bioconjugations of } Q \beta \text { VLPs } \\
\text { derivatized with azide moieties at } \\
\text { surface lysine residues were } \\
\text { performed. Complete derivatization of } \\
\text { more than } 600 \text { reactive sites per } \\
\text { particle was achieved }\end{array}$ & 365 \\
\hline $\begin{array}{l}\text { Glycans used as substrates } \\
\text { for glycosyltransferase } \\
\text { reactions to build di- and } \\
\text { trisaccharides }\end{array}$ & $\begin{array}{l}\text { Cognate receptors on the } \\
\text { appropriate beads and cells }\end{array}$ & $\begin{array}{l}\text { Potentially broad } \\
\text { applications }\end{array}$ & $\begin{array}{l}\text { The elaborated methodology provided } \\
\text { a convenient and powerful way to } \\
\text { prepare complex carbohydrate ligands } \\
\text { for clustered receptors }\end{array}$ & 366,367 \\
\hline $\begin{array}{l}\text { Cationic aa motifs by genetic } \\
\text { engineering or chemical } \\
\text { conjugation }\end{array}$ & $\begin{array}{l}\text { Inhibiting the anticoagulant } \\
\text { action of heparin }\end{array}$ & $\begin{array}{l}\text { Clinical overdose of } \\
\text { heparin }\end{array}$ & $\begin{array}{l}\text { The polycationic motifs displayed on } \\
\text { the mutated Q } \beta \text { VLPs acted as heparin } \\
\text { antagonists }\end{array}$ & $368-370$ \\
\hline $\begin{array}{l}\text { IgG-binding } \mathrm{Z} \text { domain at the } \\
\text { C-terminus of the } \mathrm{CP} \\
\text { coexpressed with native } \mathrm{CP} \\
\text { as a helper }\end{array}$ & Rather unspecific targeting & $\begin{array}{l}\text { Potentially broad } \\
\text { applications in } \\
\text { diagnostics }\end{array}$ & $\begin{array}{l}\text { This presents generation of mosaic } \\
\text { VLPs carrying the IgG-binding Z } \\
\text { domain that could be targeted to } \\
\text { antibodies displayed on the cell } \\
\text { surface or used in diagnostics }\end{array}$ & 371 \\
\hline
\end{tabular}


Table 3 (continued)

\begin{tabular}{|c|c|c|c|c|c|}
\hline Interior: packaged by & Exterior: decorated by & Addressed to & Supposed to treat & Comments & References \\
\hline \multirow[t]{9}{*}{ No specific packaging } & $\begin{array}{l}\text { Oligomannosides that are } \\
\text { modelling the 'glycan shield' } \\
\text { of HIV envelope }\end{array}$ & No cell targeting & HIV/AIDS as a model & $\begin{array}{l}\text { The oligomannose clusters were } \\
\text { recognized by monoclonal anti-HIV } \\
\text { antibody, but did not induce } \\
\text { antibodies against the HIV epitopes by } \\
\text { immunization of rabbits }\end{array}$ & 372 \\
\hline & Transferrin & Transferrin receptors & $\begin{array}{l}\text { Potentially broad } \\
\text { applications in } \\
\text { diagnostics and therapy }\end{array}$ & $\begin{array}{l}\text { This approach allowed cellular } \\
\text { internalization of chimeric VLPs } \\
\text { through clathrin-mediated } \\
\text { endocytosis }\end{array}$ & 373 \\
\hline & $\overline{\mathrm{DNA}}$ & No cell targeting & $\begin{array}{l}\text { Potentially broad } \\
\text { applications in } \\
\text { nanotechnology }\end{array}$ & $\begin{array}{l}\text { A noncompact lattice was created by } \\
\text { DNA-programmed crystallization } \\
\text { using surface-modified Q } \beta \text { VLPs and } \\
\text { gold nanoparticles, engineered to have } \\
\text { similar effective radii }\end{array}$ & 374 \\
\hline & Poly(2-oxazoline) & No cell targeting & $\begin{array}{l}\text { Potentially broad } \\
\text { applications in } \\
\text { diagnostics and therapy }\end{array}$ & $\begin{array}{l}\text { This showed that the size and content } \\
\text { of VLP-polymer constructs could be } \\
\text { controlled by changing the polymer } \\
\text { chain length and attachment density. } \\
\text { The system is universal because of the } \\
\text { convenient click chemistry } \\
\text { applications }\end{array}$ & 375 \\
\hline & $\begin{array}{l}\text { Conjugation of azide- and } \\
\text { alkyne-containing proteins }\end{array}$ & $\begin{array}{l}\text { Broad spectrum of potential } \\
\text { targeting }\end{array}$ & $\begin{array}{l}\text { Tumors and other } \\
\text { possible targets }\end{array}$ & See above, the same for MS2 & 174 \\
\hline & $\begin{array}{l}\text { Modification via the copper- } \\
\text { catalyzed azide-alkyne } \\
\text { cycloaddition (CuAAC) } \\
\text { reaction }\end{array}$ & $\begin{array}{l}\text { No definite cell targeting } \\
\text { specified }\end{array}$ & $\begin{array}{l}\text { Potentially broad } \\
\text { applications in therapy } \\
\text { and imaging } \\
\text { diagnostics }\end{array}$ & $\begin{array}{l}\text { This is a methodology to use VLPs as } \\
\text { multivalent macroinitiators for ATRP }\end{array}$ & 376 \\
\hline & $\begin{array}{l}\text { Human EGF as a C-terminal } \\
\text { fusion to the } \mathrm{Q} \beta \mathrm{CP}\end{array}$ & EGF receptor & $\begin{array}{l}\text { Therapy based on } \\
\text { interactions with cells } \\
\text { overexpressing their } \\
\text { cognate receptor }\end{array}$ & $\begin{array}{l}\text { Mosaic particles with an } \\
\text { approximately } 5 \text { - } 12 \text { EGF molecules } \\
\text { on the VLP surface were obtained. } \\
\text { The particles were found to be } \\
\text { amenable to bioconjugation by } \\
\text { standard methods as well as the } \\
\text { high-fidelity CuAAC reaction }\end{array}$ & 377 \\
\hline & $\begin{array}{l}\text { Sulfate groups that elicit } \\
\text { heparin-like anticoagulant } \\
\text { activity }\end{array}$ & No cell targeting & $\begin{array}{l}\text { Blood coagulation - as } \\
\text { heparin-like drugs }\end{array}$ & $\begin{array}{l}\text { Following conversion of VLP surface } \\
\text { lysine groups to alkynes, the sulfated } \\
\text { ligands were attached to the VLP via } \\
\text { CuAAC; } 3-6 \text { attachment points per } \\
\text { CP monomer were modified via } \\
\text { CuAAC. The sulfated VLPs were able } \\
\text { to perturb coagulation }\end{array}$ & 378,379 \\
\hline & $\begin{array}{l}\text { Polynorbornene block } \\
\text { copolymers }\end{array}$ & No cell targeting & $\begin{array}{l}\text { Potentially broad } \\
\text { applications in therapy } \\
\text { and imaging } \\
\text { diagnostics }\end{array}$ & $\begin{array}{l}\text { Poly(norbornene-PEG)-b- } \\
\text { poly(norbornene anhydride) of three } \\
\text { molecular masses: } 5,10 \text {, and } 15 \mathrm{kDa} \\
\text { were added to lysine residues }\end{array}$ & 380 \\
\hline \multicolumn{6}{|l|}{$\varphi \mathrm{Cb} 5$} \\
\hline $\begin{array}{l}\text { Gold nanoparticles, } \\
\text { tRNA, diphtheria toxin, } \\
\text { mRNA, CpG }\end{array}$ & No decoration & No cell targeting & $\begin{array}{l}\text { Potentially broad } \\
\text { applications in therapy }\end{array}$ & $\begin{array}{l}\text { The ease with which the } \varphi \text { Cb5 CP } \\
\text { dimers can be purified and } \\
\text { reassembled into VLPs makes them } \\
\text { attractive for the internal packaging of } \\
\text { nanomaterials and the chemical } \\
\text { coupling of peptides }\end{array}$ & 77 \\
\hline
\end{tabular}

The data are presented in alphabetical order of the phage model. For each model, the studies are ordered chronologically, but at first presenting studies describing both packaging and decoration, then data with packaging only, and then data with decoration only.

oneering experiments was published in 2002 [260]. Another detailed review devoted to anticancer perspectives of nanoparticles filled with siRNA was recently published [261].

The next step in the development of VLP packaging/ targeting technology included the chemical coupling of putative cargo and targeting molecules to the outer and inner surfaces of VLPs, respectively [175, 262-267]. It has been demonstrated that MS2 VLPs can be conjugated to peptides recognizing human hepatocellular carcinoma cells and can be loaded with vastly different types of cargo, including low molecular weight chemotherapeutic drugs, siRNA cocktails, protein toxins and nanoparticles, resulting in the selective killing of target cells [268]. The packaging of $Q \beta$ VLPs with immunostimulatory CpG sequences led not only to the development of potential al- 
Table 4. The bioimaging agents on the basis of RNA phage VLPs and virions

Contrast agent Comments Refences

MS2

MS2 phage was labeled with the succinimidyl ester of $\left[\mathrm{Ru}\left(2,2^{\prime}\right.\right.$ -

bipyridine) $2\left(4,4^{\prime}\right.$-dicarboxy-2,2'-bipyridine $\left.)\right]^{2+}(\mathrm{RuBDc})$, which is a very

photostable probe that possesses favorable photophysical properties, including

a long lifetime, high quantum yield, large Stokes' shift, and highly polarized

emission. The RuBDc luminophore attacks lysine residues

The MS2(Gd-DTPA-ITC)m contrast agent was synthesized through the conjugation of premetalated Gd-DTPA-ITC (2-(4-isothiocyanatobenzyl)diethylenetriaminepentaacetic acid) to the lysine residues of MS2 VLPs (not phage) on the VLP exterior

In order to maximize the relaxivity of each $\mathrm{Gd}^{3+}$ complex attached to the phage scaffold, hydroxypyridonate-based contrast agents were used. The interior (Tyr85) and exterior (Lys106, Lys113, and the N-terminus) surfaces of 'empty' phage were targeted independently through the appropriate choice of reagents

The 'empty' shell of phage was labeled on its inside surface with $\left[{ }^{18} \mathrm{~F}\right]$ fluorobenzaldehyde through a multistep bioconjugation strategy. An aldehyde functional group was first attached to interior tyrosine residues through a diazonium coupling reaction. The aldehyde was further elaborated to an alkoxyamine functional group, which was then condensed with $\left[{ }^{18} \mathrm{~F}\right]$ fluorobenzaldehyde

Approximately 125 xenon MRI sensor molecules were incorporated in the interior of an MS2 VLPs, conferring multivalency and other properties of the VLP to the sensor molecule

The PET imaging characteristics were improved by the usage of PEG chains added to MS2 VLPs. The MS2- and MS2-PEG VLPs possessing interior DOTA chelators and labeled with ${ }^{64} \mathrm{Cu}$ were compared by injecting intravenously into mice possessing tumor xenografts

The VLPs were modified using an oxidative coupling reaction, conjugating $\sim 90$ copies of a fibrin-targeting peptide to the exterior of each protein shell. The installation of near-infrared fluorophores on the interior surface of the capsids enabled optical detection of binding to fibrin clots. The targeted capsids bound to fibrin, exhibiting higher signal-to-background ratios than control, nontargeted VLP-based nanoagents

PP7

Technetium-99m labeling of PP7 phage was achieved by a HYNIC bifunctional agent. Radiochemical purity higher than $90 \%$ was obtained

$\mathrm{Q} \beta$

The VLPs were decorated with gadolinium complexes using the $\mathrm{Cu}^{\mathrm{I}}$-mediated azide-alkyne cycloaddition reaction. The interior surface labeling was engineered by the introduction of an azide-containing unnatural amino acid into the $\mathrm{CP}$
The intensity and anisotropy decays of RuBDc when conjugated to RNA phage MS2 were examined using frequency domain fluorometry with a high-intensity, blue light-emitting diode (LED) as the modulated light source. The results showed that RuBDc can be useful for studying rotational diffusion of biological macromolecules

An MRI contrast agent was developed by conjugation of more than $500 \mathrm{Gd}$ chelate groups onto a VLP. The high density of paramagnetic centers and slow tumbling rate of modified VLPs provided enhanced T1 relaxivities up to $7,200 \mathrm{mM}^{-1} \mathrm{~s}^{-1}$ per particle. A bimodal imaging agent was generated by sequential conjugation of fluorescein and $\mathrm{Gd}^{3+}$ chelate

The phage capsids sequestering the Gd-chelates on the interior surface (attached through tyrosine residues) not only provided higher relaxivities than their exterior functionalized counterparts (which relied on lysine modification) but also exhibited improved water solubility and capsid stability. There are strong advantages to using the internal surface for contrast agent attachment, leaving the exterior surface available for the installation of tissue targeting groups

This is a first example of the positron emission tomography (PET) radiolabels that have been developed on RNA phages. Relative to fluorobenzaldehyde, the fluorine-18-labeled MS2 exhibited prolonged blood circulation time and a significantly altered excretion profile

381

271
272,382

The resulting signal amplification facilitated the detection of sensor at $0.7 \mathrm{pM}$, the lowest to that date for any molecular imaging agent used in magnetic resonance. This amplification promised the detection of chemical targets at much lower concentrations than would be possible without the VLP scaffold

The biodistribution and circulation properties of the VLP-based PET imaging agents were investigated carefully in order to realize the potential of such agents for the future use in in vivo applications

The chemically functionalized and specifically targeted VLPs were used for fibrin imaging. The modified capsids outperformed the free peptides and were shown to inhibit clot formation at effective concentrations over 10-fold lower than the monomeric peptide alone. The in vitro assessment of the capsids suggests that fibrin-targeted VLPs could be used as delivery agents to thrombi for diagnostic or therapeutic applications animals studied in mice for contrast agents based on original VLPs and VLPs with mutated

R17

The metal-ligand complex, $\left[\mathrm{Ru}\left(2,2^{\prime}\right.\right.$-bipyridine $)(2)\left(4,4^{\prime}\right.$-dicarboxy- $2,2^{\prime}$ bipyridine $)]^{2+}(\mathrm{RuBDc})$, was used as a spectroscopic probe for studying the surface aa residues hydrodynamics of biological macromolecules

The order of data presentation is the same as in table 1.

lergy vaccines (see above) but also strongly contributed to the general understanding of the mechanics of oligodeoxynucleotide-induced stimulation [217-229, 269, 270].

\section{Imaging}

The use of imaging agents in combination with RNA phage VLPs has contributed to the high-resolution and noninvasive visualization of these particles, as well as to the potential treatment of diseases [254]. The RNA phage VLP-based applications that have been developed as imaging technologies are compiled in table 4 . The first studies on the generation of nanoparticles for magnetic resonance imaging applications and the first comparisons of interior versus exterior cargo strategies appeared in the 


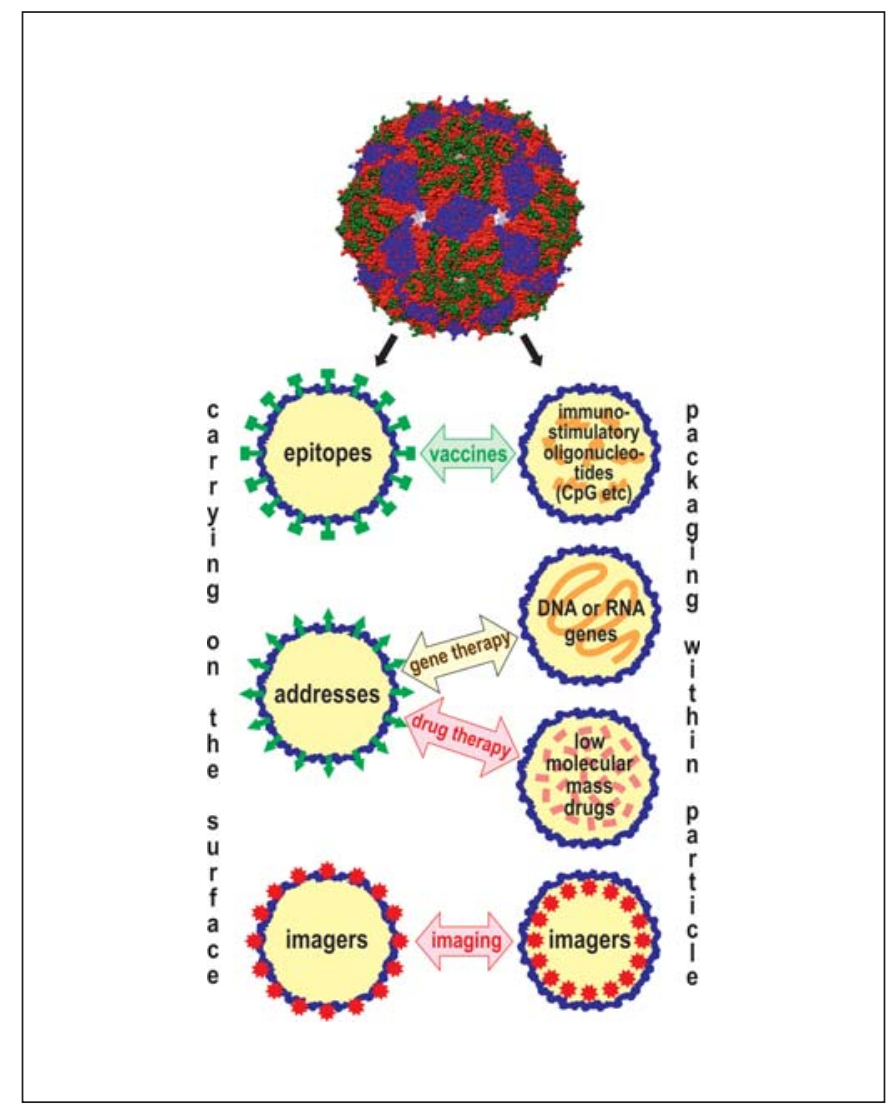

Fig. 6. General milestones of the development of RNA phage VLPs as nanotools. The $3 \mathrm{D}$ structure of the MS2 phage is presented at the top.

mid 2000s [271, 272]. Following these reports, MS2 VLPs were loaded with positron emission tomography radiolabels [273]. To date, MS2 phages and VLPs have played a leading role in bioimaging studies.

\section{Armored Polynucleotides for Diagnostic Applications}

The 'armored' nucleic acids are useful as noninfectious, easily available reagents for the quality control in the diagnosis of pathogenic viruses like HCV (hepatitis C virus). As an example of 'armored RNA' technology, MS2 VLPs were made to perform in vivo encapsidation of a desired RNA, which was accomplished by including the MS2 operator sequence on the RNA molecule to enable its packaging. The armored RNA was therefore protected from RNase digestion [274]. Recently, the creation of armored dsDNA using HBV and HPV particles was accomplished on the basis of previous work using MS2 VLPs [275]. Armored RNAs have multiple uses, such as for the detection of $\mathrm{HCV}$, severe acute respiratory syndrome coronavirus, and influenza virus RNA [276] or for the creation of unique RNA molecules harboring both tRNA and mRNA functions [277]. Perspectives on the production and practical use of MS2 VLPs for routine diagnostics including food quality control were discussed in a recent review [278].

\section{Future Perspectives}

The next milestones for the development of the RNA phage VLP field are presented in figure 6. The major tendency provides the combination of both (i) decoration of the VLP scaffolds with molecules of interest and (ii) packaging of foreign material into VLP nanocontainers.

\section{Vaccine Design}

Vaccines will remain a classic area for the application of RNA phage VLPs [279]. For example, clear progress in vaccine formulation and storage was achieved through a MS2 VLP-based papillomavirus vaccine [280]. RNA phage $\mathrm{CP}$ properties can be used in combination with other possible vaccine carriers, such as retroviral platforms, with a special goal to improve RNA packaging and delivery [281].

\section{Peptide Display}

MS2 VLPs [160] and Q $\beta$ phage [32] offer favorable alternatives to filamentous bacteriophages for the display of immunologically active peptides. Recently, a tumorassociated antigen was identified using MS2 peptide-display technology [282], confirming the importance of such a methodology for future studies.

\section{Nanomachines}

RNA phage VLPs are regarded as potential components of future nanomachines, which is a general term for a machine ranging in size from $1 \mathrm{~nm}$ to $1 \mu \mathrm{m}$. Perspectives on the revolutionary nanoscale engineering of RNA phage VLPs as natural prefabricated scaffolds to contain molecules in precisely defined arrays were described in a recent review [253]. The future of VLP-derived materials [for chemical strategies and details of VLP bioconjugation technologies, see 283] is quite impressive because the number of methods that can be used to change both the interior and exterior surfaces of capsids by the incorporation of organic and inorganic compounds is unlimited. Further development of VLPs with defined antigenic and immunogenic properties, as well as VLPs with improved 
packaging and targeting capabilities, will create novel viral nanotechnology applications and is expected to produce nanomachines with rationally designed characteristics. For example, an interesting new approach is exemplified by the use of DNA as a scaffold to arrange MS2 VLPs into one-dimensional arrays with precise nanoscale positioning [284]. Such bioinspired plasmonic nanostructures may provide a flexible design base for manipulating photonic excitation and photoemission [285].

\section{Search for New RNA Phage Vectors}

The clear differences that exist in RNA phage VLP structures, stabilities, and reconstruction capacities have provoked extensive studies aimed at identifying novel members of the Leviviridae family. Out of such efforts, 19 new genomes of icosahedral RNA phages [286], genomes from the phages M [287], C-1 and HgalI [288], DL52 and DL54 [289], from a so-called JS-like group [290] and of the phages EC and MB [291], have been described.

A recent survey of metagenomic databases revealed 158 partial single-stranded RNA phage genome sequences belonging to about 120 distinct phylotypes [292]. Sixtysix of the genomes contained a putative open reading frame predicted to be the CP [292]. Novel RNA phage sequences were present in samples collected from a range of ecological niches worldwide, including invertebrates and extreme microbial sediment, demonstrating that they are more widely distributed than previously recognized [292]. These genomes are expected to undergo studies of CP gene expression as well as elucidation of their 3D capsid structures, and will potentially serve in new applications.

\section{Structural Studies}

3D structural investigations have revealed unexpected capabilities of RNA phage capsids, such as their ability to transform into $\mathrm{T}=1$ [77] or rod-like [157] structures. Moreover, such studies have contributed worthwhile information towards understanding protein folding and virus assembly [293]. Additional important directions for future studies involve the elucidation of VLP surface properties in the context of the presence of internal RNA, as reported previously [294], and/or the external display of foreign sequences of different origins, such as oligonucleotides, peptides, sugars, and metal ions. Such studies would be helpful for the prediction of VLP characteristics in the context of aqueous and nonaqueous media, as well as under different biological conditions, which should facilitate the use of these particles as vaccines and/ or gene therapy tools.

\section{Acknowledgements}

We thank Dr. Maija Bundule, Dr. Indulis Cielens, Dr. Dzidra Dreilina, Dr. Juris Jansons, Dr. Andris Kazaks, Dr. Janis Klovins, Dr. Janis Rumnieks, Dr. Dace Skrastina, Dr. Irina Sominskaya, Dr. Arnis Strods, Dr. Alexander Tsimanis, Dr. Inta Vasiljeva, Dr. Tatjana Voronkova, and Ms. Inara Akopjana (Riga) for their contributions and sharing of unpublished data. We are grateful to Prof. Dr. Rüdiger Schmitt (Regensburg) for the first N-terminal aa sequence of the AP205 CP and to Prof. Dr. Wolfram H. Gerlich (Giessen) for his critical reading of the manuscript and helpful comments.

\section{References}

1 Loeb T, Zinder ND: A bacteriophage containing RNA. Proc Natl Acad Sci USA 1961;47: 282-289.

2 Davis J, Strauss J, Sinsheimer R: Bacteriophage MS2: another RNA phage. Science 1961;134:1427.

3 Paranchych W, Graham AF: Isolation and properties of an RNA-containing bacteriophage. J Cell Comp Physiol 1962;60:199-208.

4 Marvin DA, Hoffmann-Berling H: Physical and chemical properties of 2 new small bacteriophages. Nature 1963;197:517-518.

5 Hofschneider PH: Untersuchungen über 'kleine' E. coli K12 Bacteriophagen. I. Mitt.: Die Isolierung und einige Eigenschaften der 'kleinen' Bacteriophagen M12, M13 und M20. Z Naturforsch 1963;18b:203-205.
6 Watanabe I: Persistent infection with an RNA bacteriophage. Nippon Rinsho 1964;22:243251.

7 Gren EJ: Regulatory Mechanisms of RNA Bacteriophage Replication (in Russian). Riga, Zinatne, 1974.

8 Zinder ND (ed): RNA Phages. Cold Spring Harbor, Cold Spring Harbor Laboratory, 1975.

9 Zinder ND: Portraits of viruses: RNA phage. Intervirology 1980;13:257-270.

10 Miyake T, Shiba T, Sakurai T, Watanabe I: Isolation and properties of two new RNA phages SP and FI. Jpn J Microbiol 1969;13: 375-382.
11 Aoi T, Furuse K, Watanabe I, Osawa S: Isolation and properties of temperature-sensitive mutants of group II RNA phage GA (in Japanese). Uirusu 1973;23:19-28.

12 Schmidt JM, Stanier RY: Isolation and characterization of bacteriophages active against stalked bacteria. J Gen Microbiol 1965;39:95107.

13 Bradley D: The structure and infective process of a Pseudomonas aeruginosa bacteriophage containing ribonucleic acid. J Gen Microbiol 1966;45:83-96.

14 Olsen RH, Thomas DD: Characteristics and purification of PRR1, an RNA phage specific for the broad host range Pseudomonas R1822 drug resistance plasmid. J Virol 1973;12: 1560-1567. 
15 Coffi H: Lysotypie des Acinetobacter; MSc thesis, Laval University, Quebec, 1995.

16 Klovins J, Overbeek GP, van den Worm SH, Ackermann HW, van Duin J: Nucleotide sequence of a ssRNA phage from Acinetobacter: kinship to coliphages. J Gen Virol 2002;83: 1523-1533.

17 International Committee on Taxonomy of Viruses: Virus Taxonomy: 2014 Release. EC 46, Montreal, Canada, July 2014. http://ictvonline.org/virusTaxonomy.asp.

18 Inokuchi Y, Hirashima A. Watanabe I: Comparison of the nucleotide sequences at the 3 '-terminal region of RNAs from RNA coliphages. J Mol Biol 1982;158:711-730.

19 NCBI: Taxonomy browser. http://www.ncbi. nlm.nih.gov/Taxonomy/Browser/wwwtax. cgi?id=11989.

20 Krueger RG: Serological relatedness of the ribonucleic acid-containing coliphages. J Virol 1969;4:567-573.

21 Furuse K: Distribution of coliphages in the environment: general considerations; in Goyal SM, Gerba CP, Bitton G (eds): Phage Ecology. New York, John Wiley, 1987, pp 87-124.

22 Miyake T, Haruna I, Shiba T, Ito YH, Yamane $\mathrm{K}$ : Grouping of RNA phages based on the template specificity of their RNA replicases. Proc Natl Acad Sci USA 1971;68:2022-2024.

23 Hsu FC, Shieh YS, van Duin J, Beekwilder MJ, Sobsey MD: Genotyping male-specific RNA coliphages by hybridization with oligonucleotide probes. Appl Environ Microbiol 1995; 61:3960-3966.

24 Friedman SD, Cooper EM, Calci KR, Genthner FJ: Design and assessment of a real time reverse transcription-PCR method to genotype single-stranded RNA male-specific coliphages (family Leviviridae). J Virol Methods 2011;173:196-202.

25 Guan D, Joerger RD, Kniel KE, Calci KR, Hicks DT, Pivarnik LF, Hoover DG: Effect of high hydrostatic pressure on four genotypes of F-specific RNA bacteriophages. J Appl Microbiol 2007;102:51-56.

26 Muniesa M, Payan A, Moce-Llivina L, Blanch AR, Jofre J: Differential persistence of F-specific RNA phage subgroups hinders their use as single tracers for faecal source tracking in surface water. Water Res 2009;43:1559-1564.

27 Hartard C, Rivet R, Banas S, Gantzer C: Occurrence of and sequence variation among $\mathrm{F}$ specific RNA bacteriophage subgroups in feces and wastewater of urban and animal origins. Appl Environ Microbiol 2015;81: 6505-6515.

28 Weiner AM, Weber K: Natural read-through at the UGA termination signal of $Q \beta$ coat protein cistron. Nat New Biol 1971;234:206-209.

29 Hofstetter H, Monstein HJ, Weissmann C: The readthrough protein $\mathrm{A} 1$ is essential for the formation of viable $Q \beta$ particles. Biochim Biophys Acta 1974;374:238-251.
30 Engelberg-Kulka H, Dekel L, Israeli-Reches M: Streptomycin-resistant Escherichia coli mutant temperature sensitive for the production of Q $\beta$-infective particles. J Virol 1977;21: $1-6$.

31 Engelberg-Kulka H, Israeli-Reches M, Dekel L, Friedmann A: Q $\beta$-defective particles produced in a streptomycin-resistant Escherichia coli mutant. J Virol 1979;29:1107-1117.

32 Skamel C, Aller SG, Bopda Waffo A: In vitro evolution and affinity-maturation with coliphage Q $\beta$ display. PLoS One 2014;9:e113069. 33 Bollback JP, Huelsenbeck JP: Phylogeny, genome evolution, and host specificity of singlestranded RNA bacteriophage (family Leviviridae). J Mol Evol 2001;52:117-128.

34 Goessens WH, Driessen AJ, Wilschut J, van Duin J: A synthetic peptide corresponding to the C-terminal 25 residues of phage MS2 coded lysis protein dissipates the protonmotive force in Escherichia coli membrane vesicles by generating hydrophilic pores. EMBO J 1988; 7:867-873.

35 Pierrel J: An RNA phage Lab: MS2 in Walter Fiers' laboratory of molecular biology in Ghent, from genetic code to gene and genome, 1963-1976. J Hist Biol 2012;45:109138.

36 Fiers W, Contreras R, Duerinck F, Haegeman G, Iserentant D, Merregaert J, Min Jou W, Molemans F, Raeymaekers A, van den Berghe A, Volckaert G, Ysebaert M: Complete nucleotide sequence of bacteriophage MS2 RNA: primary and secondary structure of the replicase gene. Nature 1976;260:500-507.

37 Crowther RA, Amos LA, Finch JT: Three-dimensional image reconstructions of bacteriophages R17 and f2. J Mol Biol 1975;98:631635.

38 Caspar DL, Klug A: Physical principles in the construction of regular viruses. Cold Spring Harb Symp Quant Biol 1962;27:1-24.

39 Coleman J, Hirashima A, Inokuchi Y, Green PJ, Inouye M: A novel immune system against bacteriophage infection using complementary RNA (micRNA). Nature 1985;315:601603.

40 Hirashima A, Sawaki S, Inokuchi Y, Inouye $\mathrm{M}$ : Engineering of the mRNA-interfering complementary RNA immune system against viral infection. Proc Natl Acad Sci USA 1986; 83:7726-7730.

41 Krivisky AS, Cherban TP: Comparative study of the lethal and mutagenic action of chemical agents and radiations on the MS2 bacteriophage and its infectious RNA (in French). Arch Roum Pathol Exp Microbiol 1969;28: 866-876.

42 Wigginton KR, Pecson BM, Sigstam T, Bosshard F, Kohn T: Virus inactivation mechanisms: impact of disinfectants on virus function and structural integrity. Environ Sci Technol 2012;46:12069-12078.

43 Kimmitt PT, Redway KF: Evaluation of the potential for virus dispersal during hand drying: a comparison of three methods. J Appl Microbiol 2016;120:478-486.
44 Tomas ME, Kundrapu S, Thota P, Sunkesula VC, Cadnum JL, Mana TS, Jencson A, O’Donnell M, Zabarsky TF, Hecker MT, Ray AJ, Wilson BM, Donskey CJ: Contamination of health care personnel during removal of personal protective equipment. JAMA Intern Med 2015;175:1904-1910.

45 Verbyla ME, Mihelcic JR: A review of virus removal in wastewater treatment pond systems. Water Res 2015;71:107-124.

46 McAlister M, Aranha H, Larson R: Use of bacteriophages as surrogates for mammalian viruses. Dev Biol (Basel) 2004;118:89-98.

47 Sinclair RG, Rose JB, Hashsham SA, Gerba $\mathrm{CP}$, Haas CN: Criteria for selection of surrogates used to study the fate and control of pathogens in the environment. Appl Environ Microbiol 2012;78:1969-1977.

48 Liu J, Ochieng C, Wiersma S, Ströher U, Towner JS, Whitmer S, Nichol ST, Moore CC, Kersh GJ, Kato C, Sexton C, Petersen J, Massung R, Hercik C, Crump JA, Kibiki G, Maro A, Mujaga B, Gratz J, Jacob ST, Banura P, Scheld WM, Juma B, Onyango CO, Montgomery JM, Houpt E, Fields B: Development of a TaqMan array card for acute-febrile-illness outbreak investigation and surveillance of emerging pathogens, including Ebola virus. J Clin Microbiol 2016;54:49-58.

49 Lodish HF: Translational control of protein synthesis: the early years. J Biol Chem 2012; 287:36528-36535.

50 Pumpen PP, Gren EJ: Role of protein synthesis in the regulation of replication of RNAcontaining bacteriophages (in Russian). Dokl Akad Nauk SSSR 1975;224:246-248.

51 Pumpen P, Bauman V, Dishler A, Gren EJ: Control of replication in RNA bacteriophages. J Virol 1978;28:725-735.

52 Lampasona AA, Czaplinski K: RNA voyeurism: a coming of age story. Methods 2016;98: $10-17$.

53 Bensidoun P, Raymond P, Oeffinger M, Zenklusen D: Imaging single mRNAs to study dynamics of mRNA export in the yeast $\mathrm{Sac}$ charomyces cerevisiae. Methods 2016;98:104114

54 Gong C, Maquat LE: Affinity purification of long noncoding RNA-protein complexes from formaldehyde cross-linked mammalian cells. Methods Mol Biol 2015;1206:81-86.

55 Hocine S, Raymond P, Zenklusen D, Chao JA, Singer RH: Single-molecule analysis of gene expression using two-color RNA labeling in live yeast. Nat Methods 2013;10:119-121.

56 Bardwell VJ, Wickens M: Purification of RNA and RNA-protein complexes by an R17 coat protein affinity method. Nucleic Acids Res 1990;18:6587-6594.

57 Dahlman JE, Abudayyeh OO, Joung J, Gootenberg JS, Zhang F, Konermann S: Orthogonal gene knockout and activation with a catalytically active Cas9 nuclease. Nat Biotechnol 2015;33:1159-1161. 
58 Remaut E, Waele PD, Marmenout A, Stanssens P, Fiers W: Functional expression of individual plasmid-coded RNA bacteriophage MS2 genes. EMBO J 1982;1:205-209.

59 Kastelein RA, Berkhout B, Overbeek GP, van Duin J: Effect of the sequences upstream from the ribosome-binding site on the yield of protein from the cloned gene for phage MS2 coat protein. Gene 1983;23:245-254.

60 Kozlovskaia TM, Pumpen PP, Dreilinia DE, Tsimanis AIu, Ose VP,Tsibinogin VV, Gren EJ: Formation of capsid-like structures as a result of expression of the cloned gene of the envelope protein of the RNA-containing bacteriophage fr (in Russian). Dokl Akad Nauk SSSR 1986;287:452-455.

61 Adhin MR, Hirashima A, van Duin J: Nucleotide sequence from the ssRNA bacteriophage JP34 resolves the discrepancy between serological and biophysical classification. Virology 1989;170:238-242.

62 Ni CZ, White CA, Mitchell RS, Wickersham J, Kodandapani R, Peabody DS, Ely KR: Crystal structure of the coat protein from the GA bacteriophage: model of the unassembled dimer. Protein Sci 1996;5:2485-2493.

63 Kozlovska TM, Cielens I, Dreilina D, Dislers A, Baumanis V, Ose V, Pumpens P: Recombinant RNA phage $\mathrm{Q} \beta$ capsid particles synthesized and self-assembled in Escherichia coli. Gene 1993;137:133-137.

64 Priano C, Arora R, Butke J, Mills DR: A complete plasmid-based complementation system for RNA coliphage $\mathrm{Q} \beta$ : three proteins of bacteriophages Q $\beta$ (group III) and SP (group IV) can be interchanged. J Mol Biol 1995;249: 283-297.

65 Lim F, Downey TP, Peabody DS: Translational repression and specific RNA binding by the coat protein of the Pseudomonas phage PP7. J Biol Chem 2001;276:22507-22513.

66 Caldeira JC, Peabody DS: Stability and assembly in vitro of bacteriophage PP7 virus-like particles. J Nanobiotechnol 2007;5:10.

67 Tissot AC, Renhofa R, Schmitz N, Cielens I, Meijerink E, Ose V, Jennings GT, Saudan P, Pumpens P, Bachmann MF: Versatile viruslike particle carrier for epitope based vaccines. PLoS One 2010;5:e9809.

68 Spohn G, Jennings GT, Martina BE, Keller I, Beck M, Pumpens P, Osterhaus AD, Bachmann MF: A VLP-based vaccine targeting domain III of the West Nile virus E protein protects from lethal infection in mice. Virol J 2010;7:146.

69 Persson M, Tars K, Liljas L: The capsid of the small RNA phage PRR1 is stabilized by metal ions. J Mol Biol 2008;383:914-922.

70 Plevka P, Kazaks A, Voronkova T, Kotelovica S, Dishlers A, Liljas L, Tars K: The structure of bacteriophage $\varphi \mathrm{Cb} 5$ reveals a role of the RNA genome and metal ions in particle stability and assembly. J Mol Biol 2009;391:635647.
71 Spirin AS, Baranov VI, Ryabova LA, Ovodov SY, Alakhov YB: A continuous cell-free translation system capable of producing polypeptides in high yield. Science 1988;242:11621164 .

72 Bundy BC, Franciszkowicz MJ, Swartz JR: Escherichia coli-based cell-free synthesis of virus-like particles. Biotechnol Bioeng 2008; 100:28-37.

73 Rumnieks J, Ose V, Tars K, Dislers A, Strods A, Cielens I, Renhofa R: Assembly of mixed rod-like and spherical particles from group I and II RNA bacteriophage coat proteins. Virology 2009;391:187-194.

74 Legendre D, Fastrez J: Production in Saccharomyces cerevisiae of MS2 virus-like particles packaging functional heterologous mRNAs. J Biotechnol 2005;117:183-194.

75 Freivalds J, Dislers A, Ose V, Skrastina D, Cielens I, Pumpens P, Sasnauskas K, Kazaks A: Assembly of bacteriophage $Q \beta$ virus-like particles in yeast Saccharomyces cerevisiae and Pichia pastoris. J Biotechnol 2006;123: 297-303.

76 Freivalds J, Rumnieks J, Ose V, Renhofa R, Kazaks A: High-level expression and purification of bacteriophage GA virus-like particles from yeast Saccharomyces cerevisiae and $P i$ chia pastoris. Acta Universitatis Latviensis Biol 2008;745:75-85.

77 Freivalds J, Kotelovica S, Voronkova T, Ose V, Tars K, Kazaks A: Yeast-expressed bacteriophage-like particles for the packaging of nanomaterials. Mol Biotechnol 2014;56:102110.

78 Rossmann MG: Structure of viruses: a short history. Q Rev Biophys 2013;46:133-180.

79 Schwartz FM, Zinder ND: Crystalline aggregates in bacterial cells infected with the RNA bacteriophage f2. Virology 1963;21:276-278.

80 de Petris S, Nava G: Sex specific bacteriophages of E. coli K12. II. Electron microscope observations on the structure and intracellular multiplication of bacteriophage $\mu 2$. Giorn Microbiol 1963;11:1-7.

81 Franklin RM, Granboulan N: Ultrastructure of Escherichia coli cells infected with bacteriophage R17. J Bacteriol 1966;91:834-848.

82 Pumpens P, Grens E: Artificial genes for chimeric virus-like particles; in Khudyakov YE, Fields HA (eds): Artificial DNA. Methods and Applications. Boca Raton, CRC Press LLC, 2002, pp 249-327.

83 Valegård K, Unge T, Montelius I, Strandberg B, Fiers W: Purification, crystallization and preliminary X-ray data of the bacteriophage MS2. J Mol Biol 1986;190:587-591.

84 Valegård K, Liljas L, Fridborg K, Unge T: The three-dimensional structure of the bacterial virus MS2. Nature 1990;345:36-41.

85 Valegård K, Liljas L, Fridborg K, Unge T: Structure determination of the bacteriophage MS2. Acta Crystallogr B 1991;47:949-960.

86 Golmohammadi R, Valegård K, Fridborg K, Liljas L: The refined structure of bacteriophage MS2 at $2.8 \AA$ resolution. J Mol Biol 1993;234:620-639.
87 Stonehouse NJ, Valegård K, Golmohammadi R, van den Worm S, Walton C, Stockley PG, Liljas L: Crystal structures of MS2 capsids with mutations in the subunit FG loop. J Mol Biol 1996;256:330-339.

88 Min Jou W, Raeymaekers A, Fiers W: Crystallization of bacteriophage MS2. Eur J Biochem 1979;102:589-594.

89 Bundule M, Pumpens P, Ose V, Valegård K, Liljas L: Crystallization of bacteriophage $\mathrm{fr}$ and its recombinant capsids. J Mol Biol 1993;232:1005-1006.

90 Liljas L, Fridborg K, Valegård K, Bundule M, Pumpens P: Crystal structure of bacteriophage fr capsids at $3.5 \AA$ resolution. J Mol Biol 1994;244:279-290.

91 Tars K, Bundule M, Fridborg K, Liljas L: The crystal structure of bacteriophage GA and a comparison of bacteriophages belonging to the major groups of Escherichia coli leviviruses. J Mol Biol 1997;271:759-773.

92 Valegård K, Fridborg K, Liljas L: Crystallization and preliminary $\mathrm{X}$-ray diffraction studies of the bacteriophage $\mathrm{Q} \beta$. Acta Crystallogr D Biol Crystallogr 1994;50:105-109.

93 Golmohammadi R, Fridborg K, Bundule M, Valegård K, Liljas L: The crystal structure of bacteriophage $\mathrm{Q} \beta$ at $3.5 \AA$ resolution. Structure 1996;4:543-554.

94 Tars K, Fridborg K, Bundule M, Liljas L: Structure determination of bacteriophage PP7 from Pseudomonas aeruginosa: from poor data to a good map. Acta Crystallogr D Biol Crystallogr 2000;56:398-405.

95 Tars K, Fridborg K, Bundule M, Liljas L: The three-dimensional structure of bacteriophage PP7 from Pseudomonas aeruginosa at $3.7-\AA$ resolution. Virology 2000;272:331337.

96 Lim F, Peabody DS: RNA recognition site of PP7 coat protein. Nucleic Acids Res 2002;30: 4138-4144.

97 Nap RJ, Božič AL, Szleifer I, Podgornik R The role of solution conditions in the bacteriophage PP7 capsid charge regulation. Biophys J 2014;107:1970-1979.

98 Hull R: The stabilization of the particles of turnip rosette virus and of other members of the southern bean mosaic virus group. $\mathrm{Vi}$ rology 1977;79:58-66.

99 Shishovs M, Rumnieks J, Diebholder C, Jaudzems K, Kazaks A, Pintacuda G, Koning R, Tars K: Structure of AP205 coat protein reveals circular permutation in ssRNA bacteriophage. J Mol Biol. 2016;428:4267-4279.

$100 \mathrm{Ni}$ CZ, Syed R, Kodandapani R, Wickersham J, Peabody DS, Ely KR: Crystal structure of the MS2 coat protein dimer: implications for RNA binding and virus assembly. Structure 1995;3:255-263.

101 Peabody DS, Lim F: Complementation of RNA binding site mutations in MS2 coat protein heterodimers. Nucleic Acids Res 1996;24:2352-2359. 
102 Plevka P, Tars K, Liljas L: Structure and stability of icosahedral particles of a covalent coat protein dimer of bacteriophage MS2. Protein Sci 2009; 18:1653-1661.

103 Plevka P, Tars K, Liljas L: Crystal packing of a bacteriophage MS2 coat protein mutant corresponds to octahedral particles. Protein Sci 2008;17:1731-1739.

104 Valegård K, Murray JB, Stockley PG, Stonehouse NJ, Liljas L: Crystal structure of an RNA bacteriophage coat protein-operator complex. Nature 1994;371:623-626.

105 Stockley PG, Stonehouse NJ, Murray JB, Goodman ST, Talbot SJ, Adams CJ, Liljas L, Valegård K: Probing sequence-specific RNA recognition by the bacteriophage MS2 coat protein. Nucleic Acids Res 1995;23:25122518.

106 Valegård K, Murray JB, Stonehouse NJ, van den Worm S, Stockley PG, Liljas L: The three-dimensional structures of two complexes between recombinant MS2 capsids and RNA operator fragments reveal sequence-specific protein-RNA interactions. J Mol Biol 1997;270:724-738.

107 Lago H, Fonseca SA, Murray JB, Stonehouse NJ, Stockley PG: Dissecting the key recognition features of the MS2 bacteriophage translational repression complex. Nucleic Acids Res 1998;26:1337-1344.

108 van den Worm SH, Stonehouse NJ, Valegård K, Murray JB, Walton C, Fridborg K, Stockley PG, Liljas L: Crystal structures of MS2 coat protein mutants in complex with wildtype RNA operator fragments. Nucleic Acids Res 1998;26:1345-1351.

109 Peabody DS, Chakerian A: Asymmetric contributions to RNA binding by the $\mathrm{Thr}^{45}$ residues of the MS2 coat protein dimer. J Biol Chem 1999;274:25403-25410.

110 Lim F, Spingola M, Peabody DS: Altering the RNA binding specificity of a translational repressor. J Biol Chem 1994;269:9006-9010.

111 Lim F, Peabody DS: Mutations that increase the affinity of a translational repressor for RNA. Nucleic Acids Res 1994;22:37483752.

112 Convery MA, Rowsell S, Stonehouse NJ, Ellington AD, Hirao I, Murray JB, Peabody DS, Phillips SE, Stockley PG: Crystal structure of an RNA aptamer-protein complex at 2.8 Å resolution. Nat Struct Biol 1998;5:133139.

113 Rowsell S, Stonehouse NJ, Convery MA, Adams CJ, Ellington AD, Hirao I, Peabody DS, Stockley PG, Phillips SE: Crystal structures of a series of RNA aptamers complexed to the same protein target. Nat Struct Biol 1998;5:970-975.

114 Grahn E, Stonehouse NJ, Murray JB, van den Worm S, Valegård K, Fridborg K, Stockley PG, Liljas L: Crystallographic studies of RNA hairpins in complexes with recombinant MS2 capsids: implications for binding requirements. RNA 1999;5:131-138.
115 Horn WT, Convery MA, Stonehouse NJ, Adams CJ, Liljas L, Phillips SE, Stockley PG: The crystal structure of a high affinity RNA stem-loop complexed with the bacteriophage MS2 capsid: further challenges in the modeling of ligand-RNA interactions. RNA 2004;10:1776-1782.

116 Persson M, Tars K, Liljas L: PRR1 coat protein binding to its RNA translational operator. Acta Crystallogr D Biol Crystallogr 2013;69:367-372.

117 Chao JA, Patskovsky Y, Almo SC, Singer RH: Structural basis for the coevolution of a viral RNA-protein complex. Nat Struct Mol Biol 2008;15:103-105.

118 Rumnieks J, Tars K: Crystal structure of the bacteriophage $\mathrm{Q} \beta$ coat protein in complex with the RNA operator of the replicase gene. I Mol Biol 2014;426:1039-1049.

119 Koning R, van den Worm S, Plaisier JR, van Duin J, Pieter Abrahams J, Koerten H: Visualization by cryo-electron microscopy of genomic RNA that binds to the protein capsid inside bacteriophage MS2. J Mol Biol 2003; $332: 415-422$

120 Toropova K, Basnak G, Twarock R, Stockley PG, Ranson NA: The three-dimensional structure of genomic RNA in bacteriophage MS2: implications for assembly. J Mol Biol 2008;375:824-836.

121 Rolfsson Ó, Middleton S, Manfield IW, White SJ, Fan B, Vaughan R, Ranson NA, Dykeman E, Twarock R, Ford J, Cheng Kao C, Stockley PG: Direct evidence for packaging signal-mediated assembly of bacteriophage MS2. J Mol Biol 2016;428:431-448.

122 Stockley PG, White SJ, Dykeman E, Manfield I, Rolfsson O, Patel N, Bingham R, Barker A, Wroblewski E, Chandler-Bostock R, Weiß EU, Ranson NA, Tuma R, Twarock R: Bacteriophage MS2 genomic RNA encodes an assembly instruction manual for its capsid. Bacteriophage 2016;6:e1157666.

123 Dent KC, Thompson R, Barker AM, Hiscox JA, Barr JN, Stockley PG, Ranson NA: The asymmetric structure of an icosahedral virus bound to its receptor suggests a mechanism for genome release. Structure 2013;21:12251234.

124 Koning RI, Gomez-Blanco J, Akopjana I, Vargas J, Kazaks A, Tars K, Carazo JM, Koster AJ: Asymmetric cryo-EM reconstruction of phage MS2 reveals genome structure in situ. Nat Commun 2016;7: 12524

125 Kuzmanovic DA, Elashvili I, Wick C, O'Connell C, Krueger S: The MS2 coat protein shell is likely assembled under tension: a novel role for the MS2 bacteriophage A protein as revealed by small-angle neutron scattering. J Mol Biol 2006;355:1095-1111.

126 Rowlands DT Jr: Precipitation and neutralization of bacteriophage $\mathrm{f} 2$ by rabbit antibodies. J Immunol 1967;98:958-964.

127 Rappaport I: An analysis of the inactivation of MS2 bacteriophage with antiserum. J Gen Virol 1970;6:25-32.
128 Rohrmann GF, Krueger RG: Precipitation and neutralization of bacteriophage MS-2 by rabbit antibodies. J Immunol 1970;104:353358.

129 Krueger RG: Effect of antigenic stimulation on the specificity of antibody produced by rabbits immunized with bacteriophage MS2. J Immunol 1970;104:1117-1123.

130 Snippe H, de Reuver MJ, Belder M, Willers JM: Bacteriophage MS-2 in the immune response. Int Arch Allergy Appl Immunol 1976;50:111-122.

131 Langbeheim H, Teitelbaum D, Arnon R Cellular immune response toward MS-2 phage and a synthetic fragment of its coat protein. Cell Immunol 1978;38:193-197.

132 Langbeheim H, Arnon R, Sela M: Antiviral effect on MS-2 coliphage obtained with a synthetic antigen. Proc Natl Acad Sci USA 1976;73:4636-4640.

133 Langbeheim H, Arnon R, Sela M: Adjuvant effect of a peptidoglycan attached covalently to a synthetic antigen provoking anti-phage antibodies. Immunology 1978;35:573-579.

134 Arnon R, Sela M, Parant M, Chedid L: Antiviral response elicited by a completely synthetic antigen with built-in adjuvanticity. Proc Natl Acad Sci USA 1980;77:6769-6772.

135 Steinbergs J, Kilchewska K, Lazdina U, Dishlers A, Ose V, Sällberg M, Tsimanis A Short synthetic CDR-peptides forming the antibody combining site of the monoclonal antibody against RNA bacteriophage fr neutralize the phage activity. Hum Antibodies Hybridomas 1996;7:106-112.

136 Liu JL, Zabetakis D, Goldman ER, Anderson GP: Selection and evaluation of single domain antibodies toward MS2 phage and coat protein. Mol Immunol 2013;53:118-125.

137 Borisova G., Bundule M, Grinstein E, Dreilina D, Dreimane A, Kalis J, Kozlovskaya T, Loseva V, Ose V, Pumpen P, Pushko P, Snikere D, Stankevica E, Tsibinogin V, Gren EJ: Recombinant capsid structures for exposure of protein antigenic epitopes. Mol Gen (Life Sci Adv) 1987;6:169-174.

138 Gren EJ, Pumpen P: Recombinant viral capsids as a new age of immunogenic proteins and vaccines (in Russian). J All Union Mendeleyevs Chem Soc 1988;33:531-536.

139 Mastico RA, Talbot SJ, Stockley PG: Multiple presentation of foreign peptides on the surface of an RNA-free spherical bacteriophage capsid. J Gen Virol 1993;74:541-548.

140 Kozlovskaia TM, Pushko PM, Stankevich EI Dreimane AIa, Sniker DIa, Grinstein EE, Dreilinia DE, Veinia AE, Ose VP, Pumpen P, Gren EJ: Genetically engineered mutants of the envelope protein of the RNA-containing bacteriophage fr (in Russian). Mol Biol 1988;22:731-740.

141 Pushko P, Kozlovskaya T, Sominskaya I, Brede A, Stankevica E, Ose V, Pumpens P, Grens E: Analysis of RNA phage fr coat protein assembly by insertion, deletion and substitution mutagenesis. Protein Eng 1993;6: 883-891. 
142 Axblom C, Tars K, Fridborg K, Orna L, Bundule M, Liljas L: Structure of phage fr capsids with a deletion in the FG loop: implications for viral assembly. Virology 1998;249:80-88.

143 Stonehouse NJ, Stockley PG: Effects of amino acid substitution on the thermal stability of MS2 capsids lacking genomic RNA. FEBS Lett 1993;334:355-359.

144 Peabody DS: Subunit fusion confers tolerance to peptide insertions in a virus coat protein. Arch Biochem Biophys 1997;347:8592.

145 Heal KG, Hill HR, Stockley PG, Hollingdale MR, Taylor-Robinson AW: Expression and immunogenicity of a liver stage malaria epitope presented as a foreign peptide on the surface of RNA-free MS2 bacteriophage capsids. Vaccine 2000;18:251-258.

146 Voronkova T, Grosch A, Kazaks A, Ose V, Skrastina D, Sasnauskas K, Jandrig B, Arnold W, Scherneck S, Pumpens P, Ulrich R: Chimeric bacteriophage fr virus-like particles harboring the immunodominant $\mathrm{C}$-terminal region of hamster polyomavirus VP1 induce a strong VP1-specific antibody response in mice. Viral Immunol 2002;15: 627-643.

147 Pumpens P, Razanskas R, Pushko P, Renhof R, Gusars I, Skrastina D, Ose V, Borisova G, Sominskaya I, Petrovskis I, Jansons J, Sasnauskas $\mathrm{K}$ : Evaluation of $\mathrm{HBs}, \mathrm{HBc}$, and frCP virus-like particles for expression of human papillomavirus 16 E7 oncoprotein epitopes. Intervirology 2002;45:24-32.

148 Kozlovska TM, Cielens I, Vasiljeva I, Strelnikova A, Kazaks A, Dislers A, Dreilina D, Ose V, Gusars I, Pumpens P: RNA phage Q $\beta$ coat protein as a carrier for foreign epitopes. Intervirology 1996;39:9-15.

149 Kozlovska TM, Cielens I, Vasiljeva I, Bundule M, Strelnikova A, Kazaks A, Dislers A, Dreilina D, Ose V, Gusars I, Pumpens P: Display vectors. II. Recombinant capsid of RNA bacteriophage $\mathrm{Q} \beta$ as a display moiety. Proc Latv Acad Sci 1997;51:8-12.

150 Rumnieks J, Tars K: Crystal structure of the read-through domain from bacteriophage Q $\beta$ A1 protein. Protein Sci 2011;20:17071712.

151 Smiley BK, Minion FC: Enhanced readthrough of opal (UGA) stop codons and production of Mycoplasma pneumoniae P1 epitopes in Escherichia coli. Gene 1993;134: 33-40.

152 Vasiljeva I, Kozlovska T, Cielens I, Strelnikova A, Kazaks A, Ose V, Pumpens P: Mosaic $\mathrm{Q} \beta$ coats as a new presentation model. FEBS Lett 1998;431:7-11.

153 Fehr T, Skrastina D, Pumpens P, Zinkernagel RM: T cell-independent type I antibody response against $\mathrm{B}$ cell epitopes expressed repetitively on recombinant virus particles. Proc Natl Acad Sci USA 1998;95:9477-9481.

154 Lim F, Spingola M, Peabody DS: The RNAbinding site of bacteriophage $\mathrm{Q} \beta$ coat protein. J Biol Chem 1996;271:31839-31845.
155 Spingola M, Peabody DS: MS2 coat protein mutants which bind $Q \beta$ RNA. Nucleic Acids Res 1997;25:2808-2815.

156 Pickett GG, Peabody DS: Encapsidation of heterologous RNAs by bacteriophage MS2 coat protein. Nucleic Acids Res 1993;21: 4621-4626.

157 Cielens I, Ose V, Petrovskis I, Strelnikova A, Renhofa R, Kozlovska T, Pumpens P: Mutilation of RNA phage $\mathrm{Q} \beta$ virus-like particles: from icosahedrons to rods. FEBS Lett 2000; 482:261-264.

158 van Meerten D, Olsthoorn RC, van Duin J, Verhaert RM: Peptide display on live MS2 phage: restrictions at the RNA genome level. J Gen Virol 2001;82:1797-1805.

159 Peabody DS, Manifold-Wheeler B, Medford A, Jordan SK, do Carmo Caldeira J, Chackerian B: Immunogenic display of diverse peptides on virus-like particles of RNA phage MS2. J Mol Biol 2008;380:252-263.

160 Chackerian B, Caldeira Jdo C, Peabody J, Peabody DS: Peptide epitope identification by affinity selection on bacteriophage MS2 virus-like particles. J Mol Biol 2011;409: 225-237.

161 Sominskaya I, Pushko P, Dreilina D, Kozlovskaya T, Pumpens P: Determination of the minimal length of preS1 epitope recognized by a monoclonal antibody which inhibits attachment of hepatitis B virus to hepatocytes. Med Microbiol Immunol 1992; 181:215-226.

162 Sominskaya I, Bichko V, Pushko P, Dreimane A, Snikere D, Pumpens P: Tetrapeptide QDPR is a minimal immunodominant epitope within the preS2 domain of hepatitis B virus. Immunol Lett 1992;33:169-172.

163 Sällberg M, Pushko P, Berzinsh I, Bichko V, Sillekens P, Noah M, Pumpens P, Grens E, Wahren B, Magnius LO: Immunochemical structure of the carboxy-terminal part of hepatitis B e antigen: identification of internal and surface-exposed sequences. J Gen Virol 1993;74:1335-1340.

164 Meisel H, Sominskaya I, Pumpens P, Pushko P, Borisova G, Deepen R, Lu X, Spiller GH, Kruger DH, Grens E, Gerlich WH: Finemapping and functional characterization of two immuno-dominant regions from the preS2 sequence of hepatitis B virus. Intervirology 1994;275:330-339.

165 Sobotta D, Sominskaya I, Jansons J, Meisel H, Schmitt S, Heermann K-H, Kaluza G, Pumpens P, Gerlich WH: Mapping of immunodominant B-cell epitopes and the human serum albumin-binding site in natural hepatitis B virus surface antigen of defined genosubtype. J Gen Virol 2000;81:369-378.

166 Sominskaya I, Paulij W, Jansons J, Sobotta D, Dreilina D, Sunnen C, Meisel H, Gerlich WH, Pumpens P: Fine-mapping of the B-cell epitope domain at the $\mathrm{N}$-terminus of the preS2 region of the hepatitis B surface antigen. J Immunol Meth 2002;260:251-261.
167 Jegerlehner A, Storni T, Lipowsky G, Schmid M, Pumpens P, Bachmann MF: Regulation of IgG antibody responses by epitope density and CD21-mediated costimulation. Eur J Immunol 2002;32:3305-3314.

168 Jegerlehner A, Tissot A, Lechner F, Sebbel P, Erdmann I, Kündig T, Bächi T, Storni T, Jennings G, Pumpens P, Renner WA, Bachmann MF: A molecular assembly system that renders antigens of choice highly repetitive for induction of protective $B$ cell responses. Vaccine 2002;20:3104-3112.

169 Bachmann MF, Dyer MR: Therapeutic vaccination for chronic diseases: a new class of drugs in sight. Nat Rev Drug Discov 2004;3: 81-88.

170 Dyer MR, Renner WA, Bachmann MF: A second vaccine revolution for the new epidemics of the 21 st century. Drug Discov Today 2006;11:1028-1033.

171 Bachmann MF, Jennings GT: Therapeutic vaccines for chronic diseases: successes and technical challenges. Philos Trans R Soc Lond B Biol Sci 2011;366:2815-2822.

172 Peabody DS: A viral platform for chemical modification and multivalent display. J Nanobiotechnol 2003;1:5.

173 Cheng YJ, Liang JX, Li QG: Construction of RNA-containing virus-like nanoparticles expression vector with cysteine residues on surface and fluorescent decoration (in Chinese). Yi Chuan Xue Bao 2005;32:874-878.

174 Patel KG, Swartz JR: Surface functionalization of virus-like particles by direct conjugation using azide-alkyne click chemistry. Bioconjug Chem 2011;22:376-387.

175 Hooker JM, Kovacs EW, Francis MB: Interior surface modification of bacteriophage MS2. J Am Chem Soc 2004;126:3718-3719.

176 Cheng Y, Niu J, Zhang Y, Huang J, Li Q Preparation of His-tagged armored RNA phage particles as a control for real-time reverse transcription-PCR detection of severe acute respiratory syndrome coronavirus. J Clin Microbiol 2006;44:3557-3561.

177 Udit AK, Brown S, Baksh MM, Finn MG: Immobilization of bacteriophage $\mathrm{Q} \beta$ on metal-derivatized surfaces via polyvalent display of hexahistidine tags. J Inorg Biochem 2008; 102:2142-2146.

178 Udit AK, Hollingsworth W, Choi K: Metaland metallocycle-binding sites engineered into polyvalent virus-like scaffolds. Bioconjug Chem 2010;21:399-404.

179 Strable E, Prasuhn DE Jr, Udit AK, Brown S, Link AJ, Ngo JT, Lander G, Quispe J, Potter CS, Carragher B, Tirrell DA, Finn MG: Unnatural amino acid incorporation into viruslike particles. Bioconjug Chem 2008;19:866875.

180 Smith MT, Varner CT, Bush DB, Bundy BC The incorporation of the $\mathrm{A} 2$ protein to produce novel $Q \beta$ virus-like particles using cellfree protein synthesis. Biotechnol Prog 2012; 28:549-555. 
181 Brune KD, Leneghan DB, Brian IJ, Ishizuka AS, Bachmann MF, Draper SJ, Biswas S, Howarth M: Plug-and-display: decoration of virus-like particles via isopeptide bonds for modular immunization. Sci Rep 2016;6: 19234.

182 Thrane S, Janitzek CM, Matondo S, Resende M, Gustavsson T, de Jongh WA, Clemmensen S, Roeffen W, van de Vegte-Bolmer M, van Gemert GJ, Sauerwein R, Schiller JT, Nielsen MA, Theander TG, Salanti A, Sander AF: Bacterial superglue enables easy development of efficient virus-like particle based vaccines. J Nanobiotechnol 2016;14: 30.

183 Zakeri B, Fierer JO, Celik E, Chittock EC, Schwarz-Linek U, Moy VT, Howarth M: Peptide tag forming a rapid covalent bond to a protein, through engineering a bacterial adhesin. Proc Natl Acad Sci USA 2012; 109:E690-E697.

184 Veggiani G, Zakeri B, Howarth M: Superglue from bacteria: unbreakable bridges for protein nanotechnology. Trends Biotechnol 2014;32:506-512.

185 Peabody DS, Al-Bitar L: Isolation of viral coat protein mutants with altered assembly and aggregation properties. Nucleic Acids Res 2001;29:E113.

186 Lima SM, Peabody DS, Silva JL, de Oliveira AC: Mutations in the hydrophobic core and in the protein-RNA interface affect the packing and stability of icosahedral viruses. Eur J Biochem 2004;271:135-145.

187 Ashcroft AE, Lago H, Macedo JM, Horn WT, Stonehouse NJ, Stockley PG: Engineering thermal stability in RNA phage capsids via disulphide bonds. J Nanosci Nanotechnol 2005;5:2034-2041.

188 Bundy BC, Swartz JR: Efficient disulfide bond formation in virus-like particles. J Biotechnol 2011;154:230-239.

189 Fiedler JD, Higginson C, Hovlid ML, Kislukhin AA, Castillejos A, Manzenrieder F, Campbell MG, Voss NR, Potter CS, Carragher B, Finn MG: Engineered mutations change the structure and stability of a viruslike particle. Biomacromolecules 2012;13: 2339-2348.

190 Caldeira JC, Peabody DS: Thermal stability of RNA phage virus-like particles displaying foreign peptides. J Nanobiotechnol 2011;9: 22.

191 Caldeira Jdo C, Medford A, Kines RC, Lino CA, Schiller JT, Chackerian B, Peabody DS: Immunogenic display of diverse peptides, including a broadly cross-type neutralizing human papillomavirus L2 epitope, on viruslike particles of the RNA bacteriophage PP7. Vaccine 2010;28:4384-4393.

192 Temizoz B, Kuroda E, Ishii KJ: Vaccine adjuvants as potential cancer immunotherapeutics. Int Immunol 2016;28:329-338.

193 Brencicova E, Diebold SS: Nucleic acids and endosomal pattern recognition: how to tell friend from foe? Front Cell Infect Microbiol 2013;3:37.
194 Jennings GT, Bachmann MF: Designing recombinant vaccines with viral properties: a rational approach to more effective vaccines. Curr Mol Med 2007;7:143-155.

195 Chackerian B: Virus-like particles: flexible platforms for vaccine development. Expert Rev Vaccines 2007;6:381-390.

196 Jennings GT, Bachmann MF: The coming of age of virus-like particle vaccines. Biol Chem 2008;389:521-536.

197 Bachmann MF, Jennings GT: Vaccine delivery: a matter of size, geometry, kinetics and molecular patterns. Nat Rev Immunol 2010; 10:787-796.

198 Pushko P, Pumpens P, Grens E: Development of virus-like particle technology from small highly symmetric to large complex virus-like particle structures. Intervirology 2013;56:141-165.

199 Diederich S, Gedvilaite A, Zvirbliene A, Kazaks A, Sasnauskas K, Johnson N, Ulrich RG: Virus-like particles: a versatile tool for basic and applied research on emerging and reemerging viruses; in Khudyakov Y, Pumpens P (eds): Viral Nanotechnology. Boca Raton, CRC Press, 2015, pp 137-160.

200 Lundstrom K: Cancer therapy applying viral nanoparticles; in Khudyakov Y, Pumpens $\mathrm{P}$ (eds): Viral Nanotechnology. Boca Raton, CRC Press, 2015, pp 455-466.

201 Bachmann MF, Zabel F: Immunology of virus-like particles; in Khudyakov Y, Pumpens P (eds): Viral Nanotechnology. Boca Raton, CRC Press, 2015, pp 121-128.

202 Lee KL, Twyman RM, Fiering S, Steinmetz NF: Virus-based nanoparticles as platform technologies for modern vaccines. Wiley Interdiscip Rev Nanomed Nanobiotechnol 2016;8:554-578.

203 Chackerian B, Peabody DS: Bacteriophage virus-like particles as a platform for vaccine discovery; in Khudyakov $\mathrm{Y}$, Pumpens $\mathrm{P}$ (eds): Viral Nanotechnology. Boca Raton, CRC Press, 2015, pp 239-250.

$204 \mathrm{Fu} \mathrm{Y,} \mathrm{Li} \mathrm{J:} \mathrm{A} \mathrm{novel} \mathrm{delivery} \mathrm{platform} \mathrm{based}$ on bacteriophage MS2 virus-like particles. Virus Res 2016;211:9-16.

205 Tumban E, Peabody J, Peabody DS, Chackerian B: A pan-HPV vaccine based on bacteriophage PP7 VLPs displaying broadly cross-neutralizing epitopes from the HPV minor capsid protein, L2. PLoS One 2011; 6:e23310.

206 Hunter Z, Tumban E, Dziduszko A, Chackerian B: Aerosol delivery of virus-like particles to the genital tract induces local and systemic antibody responses. Vaccine 2011;29: 4584-4592.

207 Tumban E, Peabody J, Peabody DS, Chackerian B: A universal virus-like particle-based vaccine for human papillomavirus: longevity of protection and role of endogenous and exogenous adjuvants. Vaccine 2013;31: 4647-4654.
208 Tyler M, Tumban E, Dziduszko A, Ozbun MA, Peabody DS, Chackerian B: Immunization with a consensus epitope from human papillomavirus L2 induces antibodies that are broadly neutralizing. Vaccine 2014;32: 4267-4274.

209 Tyler M, Tumban E, Peabody DS, Chackerian $B$ : The use of hybrid virus-like particles to enhance the immunogenicity of a broadly protective HPV vaccine. Biotechnol Bioeng 2014;111:2398-2406.

210 Tumban E, Muttil P, Escobar CA, Peabody J, Wafula D, Peabody DS, Chackerian B: Preclinical refinements of a broadly protective VLP-based HPV vaccine targeting the minor capsid protein, L2. Vaccine 2015;33: 3346-3353.

211 Tumban E, Peabody J, Tyler M, Peabody DS, Chackerian B: VLPs displaying a single L2 epitope induce broadly cross-neutralizing antibodies against human papillomavirus. PLoS One 2012;7:e49751.

212 Jiang RT, Schellenbacher C, Chackerian B, Roden RB: Progress and prospects for L2based human papillomavirus vaccines. Expert Rev Vaccines 2016;10:1-10.

213 Ord RL, Caldeira JC, Rodriguez M, Noe A, Chackerian B, Peabody DS, Gutierrez G, Lobo CA: A malaria vaccine candidate based on an epitope of the Plasmodium falciparum RH5 protein. Malar J 2014;13:326.

214 Crossey E, Frietze K, Narum DL, Peabody DS, Chackerian B: Identification of an immunogenic mimic of a conserved epitope on the Plasmodium falciparum blood stage antigen AMA1 using virus-like particle (VLP) peptidedisplay. PLoSOne 2015;10:e0132560.

215 Cielens I, Jackevica L, Strods A, Kazaks A, Ose V, Bogans J, Pumpens P, Renhofa R: Mosaic RNA phage VLPs carrying domain III of the West Nile virus E protein. Mol Biotechnol 2014;56:459-469.

216 Bachmann MF, Rohrer UH, Kündig TM, Bürki $\mathrm{K}$, Hengartner $\mathrm{H}$, Zinkernagel RM: The influence of antigen organization on $\mathrm{B}$ cell responsiveness. Science 1993;262:14481451.

217 Senti G, Johansen P, Haug S, Bull C, Gottschaller C, Müller P, Pfister T, Maurer P, Bachmann MF, Graf N, Kündig TM: Use of A-type $\mathrm{CpG}$ oligodeoxynucleotides as an adjuvant in allergen-specific immunotherapy in humans: a phase I/IIa clinical trial. Clin Exp Allergy 2009;39:562-570.

218 Klimek L, Willers J, Hammann-Haenni A, Pfaar O, Stocker H, Mueller P, Renner WA, Bachmann MF: Assessment of clinical efficacy of CYT003-QbG10 in patients with allergic rhinoconjunctivitis: a phase IIb study. Clin Exp Allergy 2011;41:1305-1312.

219 Klimek L, Schendzielorz P, Mueller P, Saudan P, Willers J: Immunotherapy of allergic rhinitis: new therapeutic opportunities with virus-like particles filled with $\mathrm{CpG}$ motifs. Am J Rhinol Allergy 2013;27:206-212. 
220 Beeh KM, Kanniess F, Wagner F, Schilder C, Naudts I, Hammann-Haenni A, Willers J, Stocker H, Mueller P, Bachmann MF, Renner WA: The novel TLR-9 agonist QbG10 shows clinical efficacy in persistent allergic asthma. J Allergy Clin Immunol 2013;131:866-874.

221 Casale TB, Cole J, Beck E, Vogelmeier CF, Willers J, Lassen C, Hammann-Haenni A, Trokan L, Saudan P, Wechsler ME: CYT003, a TLR9 agonist, in persistent allergic asthma - a randomized placebo-controlled phase $2 \mathrm{~b}$ study. Allergy 2015;70:1160-1168.

222 Storni T, Ruedl C, Schwarz K, Schwendener RA, Renner WA, Bachmann MF: Nonmethylated CG motifs packaged into virus-like particles induce protective cytotoxic $\mathrm{T}$ cell responses in the absence of systemic side effects. J Immunol 2004;172:1777-1785.

223 Bachmann MF, Schwarz K, Wolint P, Meijerink E, Martin S, Manolova V, Oxenius A: Cutting edge: distinct roles for $\mathrm{T}$ help and CD40/CD40 ligand in regulating differentiation of proliferation-competent memory CD8+ T cells. J Immunol 2004;173:22172221.

224 Schwarz K, Meijerink E, Speiser DE, Tissot AC, Cielens I, Renhof R, Dishlers A, Pumpens P, Bachmann MF: Efficient homologous prime-boost strategies for $\mathrm{T}$ cell vaccination based on virus-like particles. Eur J Immunol 2005;35:816-821.

225 Bachmann MF, Wolint P, Schwarz K, Jäger $\mathrm{P}$, Oxenius A: Functional properties and lineage relationship of $\mathrm{CD} 8+\mathrm{T}$ cell subsets identified by expression of IL-7 receptor a and CD62L. J Immunol 2005; 175:46864696.

226 Bessa J, Schmitz N, Hinton HJ, Schwarz K, Jegerlehner A, Bachmann MF: Efficient induction of mucosal and systemic immune responses by virus-like particles administered intranasally: implications for vaccine design. Eur J Immunol 2008;38:114-126.

227 Agnellini P, Wiesel M, Schwarz K, Wolint P, Bachmann MF, Oxenius A: Kinetic and mechanistic requirements for helping CD8 T cells. J Immunol 2008;180:1517-1525.

228 Keller SA, Bauer M, Manolova V, Muntwiler S, Saudan P, Bachmann MF: Cutting edge: limited specialization of dendritic cell subsets for MHC class II-associated presentation of viral particles. J Immunol 2010;184: 26-29.

229 Keller SA, Schwarz K, Manolova V, von Allmen CE, Kinzler MG, Bauer M, Muntwiler S, Saudan P, Bachmann MF: Innate signaling regulates cross-priming at the level of DC licensing and not antigen presentation. Eur J Immunol 2010;40:103-112.

230 Jegerlehner A, Wiesel M, Dietmeier K, Zabel F, Gatto D, Saudan P, Bachmann MF: Carrier induced epitopic suppression of antibody responses induced by virus-like particles is a dynamic phenomenon caused by carrier-specific antibodies. Vaccine 2010;28: 5503-5512.
231 Maurer P, Jennings GT, Willers J, Rohner F, Lindman Y, Roubicek K, Renner WA, Müller P, Bachmann MF: A therapeutic vaccine for nicotine dependence: preclinical efficacy, and phase I safety and immunogenicity. Eur J Immunol 2005;35:2031-2040.

232 Cornuz J, Zwahlen S, Jungi WF, Osterwalder J, Klingler K, van Melle G, Bangala Y, Guessous I, Müller P, Willers J, Maurer P, Bachmann MF, Cerny T: A vaccine against nicotine for smoking cessation: a randomized controlled trial. PLoS One 2008;3:e2547.

233 Beerli RR, Bauer M, Buser RB, Gwerder M, Muntwiler S, Maurer P, Saudan P, Bachmann MF: Isolation of human monoclonal antibodies by mammalian cell display. Proc Natl Acad Sci USA 2008;105:14336-14341.

234 Lang R, Winter G, Vogt L, Zurcher A, Dorigo B, Schimmele B: Rational design of a stable, freeze-dried virus-like particle-based vaccine formulation. Drug Dev Ind Pharm 2009;35:83-97.

235 Yin Z, Comellas-Aragones M, Chowdhury S, Bentley P, Kaczanowska K, Benmohamed L, Gildersleeve JC, Finn MG, Huang X: Boosting immunity to small tumor-associated carbohydrates with bacteriophage $\mathrm{Q} \beta$ capsids. ACS Chem Biol 2013;8:1253-1262.

236 Yin Z, Dulaney S, McKay CS, Baniel C, Kaczanowska K, Ramadan S, Finn MG, Huang $\mathrm{X}$ : Chemical synthesis of GM2 glycans, bioconjugation with bacteriophage $\mathrm{Q} \beta$, and the induction of anticancer antibodies. Chembiochem 2016;17:174-180.

237 Chackerian B, Frietze KM: Moving towards a new class of vaccines for non-infectious chronic diseases. Expert Rev Vaccines 2016; 15:561-563.

238 Klimek L, Willers J, Schendzielorz P, Kündig TM, Senti G: Immuntherapie der allergischen Rhinitis ohne Allergene? Neue Möglichkeiten einer Immunmodulation durch Vakzinierung mittels 'virus-like particles' und CpG-Motiven. HNO 2013;61:826-833.

239 Klimek L, Pfaar O: A comparison of immunotherapy delivery methods for allergen immunotherapy. Expert Rev Clin Immunol 2013;9:465-474, quiz 475.

240 Klimek L, Bachmann MF, Senti G, Kündig TM: Immunotherapy of type- 1 allergies with virus-like particles and CpG-motifs. Expert Rev Clin Immunol 2014;10:1059-1067.

241 Fettelschoss A, Zabel F, Bachmann MF: Vaccination against Alzheimer disease: an update on future strategies. Hum Vaccin Immunother 2014;10:847-851.

242 Gradman AH, Pinto R: Vaccination: a novel strategy for inhibiting the renin-angiotensin-aldosterone system. Curr Hypertens Rep 2008; 10:473-479.

243 Miller SA, Accardi JR, St Onge EL: Angiotensin II vaccine: a novel approach in the treatment of hypertension. Expert Opin Biol Ther 2008;8:1669-1673.
244 Phisitkul S: CYT-006-AngQb, a vaccine against angiotensin II for the potential treatment of hypertension. Curr Opin Investig Drugs 2009;10:269-275.

245 Sączyńska V: Influenza virus hemagglutinin as a vaccine antigen produced in bacteria. Acta Biochim Pol 2014;61:561-572.

246 Pushko P, Tumpey TM: Traditional and novel trends in influenza vaccines; in Khudyakov Y, Pumpens P (eds): Viral Nanotechnology. Boca Raton, CRC Press, 2015, pp 419-447.

247 Reyes-Sandoval A, Bachmann MF: Plasmodium vivax malaria vaccines: why are we where we are? Hum Vaccin Immunother 2013;9:2558-2565.

248 Heading CE: Drug evaluation: CYT$002-\mathrm{NicQb}$, a therapeutic vaccine for the treatment of nicotine addiction. Curr Opin Investig Drugs 2007;8:71-77.

249 Maurer P, Bachmann MF: Vaccination against nicotine: an emerging therapy for tobacco dependence. Expert Opin Investig Drugs 2007;16:1775-1783.

250 Raupach T, Hoogsteder PH, Onno van Schayck CP: Nicotine vaccines to assist with smoking cessation: current status of research. Drugs 2012;72:e1-16.

251 Hartmann-Boyce J, Cahill K, Hatsukami D, Cornuz J: Nicotine vaccines for smoking cessation. Cochrane Database Syst Rev 2012; 8:CD007072.

252 Pentel PR, LeSage MG: New directions in nicotine vaccine design and use. Adv Pharmacol 2014;69:553-580.

253 Koudelka KJ, Pitek AS, Manchester M, Steinmetz NF: Virus-based nanoparticles as versatile nanomachines. Annu Rev Virol 2015;2:379-401.

254 Tsvetkova I, Dragnea B: Principles of design of virus nanoparticles for imaging applications; in Khudyakov Y, Pumpens P (eds): Viral Nanotechnology. Boca Raton, CRC Press, 2015, pp 383-390.

255 Karimi M, Mirshekari H, Moosavi Basri SM, Bahrami S, Moghoofei M, Hamblin MR: Bacteriophages and phage-inspired nanocarriers for targeted delivery of therapeutic cargos. Adv Drug Deliv Rev 2016;106:45-62.

256 Lee EJ, Lee NK, Kim IS: Bioengineered protein-based nanocage for drug delivery. Adv Drug Deliv Rev 2016;106:157-171.

257 Wu M, Brown WL, Stockley PG: Cell-specific delivery of bacteriophage-encapsidated ricin A chain. Bioconjug Chem 1995;6:587-595.

$258 \mathrm{Wu}$ M, Brown WL, Hill HR, Stockley PG: Specific cytotoxicity against cells bearing HIV1 gp120 antigen by bacteriophage-encapsidated ricin A chain: implications for cell specific drug delivery. Biochem Soc Trans 1997;25:158S.

259 Wu M, Brown WL, Hill HR, Stockley PG: Development of a novel drug-delivery system using bacteriophage MS2 capsids. Biochem Soc Trans 1996;24:413S. 
260 Brown WL, Mastico RA, Wu M, Heal KG, Adams CJ, Murray JB, Simpson JC, Lord JM, Taylor-Robinson AW, Stockley PG: RNA bacteriophage capsid-mediated drug delivery and epitope presentation. Intervirology 2002;45:371-380.

261 Yan R, Hallam A, Stockley PG, Boyes J: Oncogene dependency and the potential of targeted RNAi-based anti-cancer therapy. Biochem J 2014;461:1-13.

262 Kovacs EW, Hooker JM, Romanini DW, Holder PG, Berry KE, Francis MB: Dual-surface-modified bacteriophage MS2 as an ideal scaffold for a viral capsid-based drug delivery system. Bioconjug Chem 2007;18: 1140-1147.

263 Carrico ZM, Romanini DW, Mehl RA, Francis MB: Oxidative coupling of peptides to a virus capsid containing unnatural amino acids. Chem Commun 2008;10:1205-1207.

$264 \mathrm{Wu}$ W, Hsiao SC, Carrico ZM, Francis MB: Genome-free viral capsids as multivalent carriers for taxol delivery. Angew Chem Int Ed Engl 2009;48:9493-9497.

265 Tong GJ, Hsiao SC, Carrico ZM, Francis MB: Viral capsid DNA aptamer conjugates as multivalent cell-targeting vehicles. J Am Chem Soc 2009; 131:11174-11178.

266 Stephanopoulos N, Carrico ZM, Francis MB: Nanoscale integration of sensitizing chromophores and porphyrins with bacteriophage MS2. Angew Chem Int Ed Engl 2009;48:9498-9502.

267 Stephanopoulos N, Tong GJ, Hsiao SC, Francis MB: Dual-surface modified virus capsids for targeted delivery of photodynamic agents to cancer cells. ACS Nano 2010;4:6014-6020.

268 Ashley CE, Carnes EC, Phillips GK, Durfee PN, Buley MD, Lino CA, Padilla DP, Phillips B, Carter MB, Willman CL, Brinker CJ, Caldeira Jdo C, Chackerian B, Wharton W, Peabody DS: Cell-specific delivery of diverse cargos by bacteriophage MS2 virus-like particles. ACS Nano 2011;5:5729-5745.

269 Hou B, Saudan P, Ott G, Wheeler ML, Ji M, Kuzmich L, Lee LM, Coffman RL, Bachmann MF, DeFranco AL: Selective utilization of Toll-like receptor and MyD88 signaling in B cells for enhancement of the antiviral germinal center response. Immunity 2011;34:375-384.

270 Link A, Zabel F, Schnetzler Y, Titz A, Brombacher F, Bachmann MF: Innate immunity mediates follicular transport of particulate but not soluble protein antigen. J Immunol 2012;188:3724-3733.

271 Anderson EA, Isaacman S, Peabody DS, Wang EY, Canary JW, Kirshenbaum K: Viral nanoparticles donning a paramagnetic coat: conjugation of MRI contrast agents to the MS2 capsid. Nano Lett 2006;6:1160-1164.

272 Hooker JM, Datta A, Botta M, Raymond KN, Francis MB: Magnetic resonance contrast agents from viral capsid shells: a comparison of exterior and interior cargo strategies. Nano Lett 2007;7:2207-2210.
273 Hooker JM, O’Neil JP, Romanini DW, Taylor SE, Francis MB: Genome-free viral capsids as carriers for positron emission tomography radiolabels. Mol Imaging Biol 2008; 10:182-191.

274 Pasloske BL, Walkerpeach CR, Obermoeller RD, Winkler M, DuBois DB: Armored RNA technology for production of ribonucleaseresistant viral RNA controls and standards. J Clin Microbiol 1998;36:3590-3594.

275 Zhang L, Sun Y, Chang L, Jia T, Wang G, Zhang R, Zhang K, Li J: A novel method to produce armored double-stranded DNA by encapsulation of MS2 viral capsids. Appl Microbiol Biotechnol 2015;99:7047-7057.

276 Wei Y, Yang C, Wei B, Huang J, Wang L, Meng S, Zhang R, Li J: RNase-resistant virus-like particles containing long chimeric RNA sequences produced by two-plasmid coexpression system. J Clin Microbiol 2008; 46:1734-1740.

277 Ponchon L, Catala M, Seijo B, El Khouri M, Dardel F, Nonin-Lecomte S, Tisné C: Coexpression of RNA-protein complexes in Escherichia coli and applications to RNA biology. Nucleic Acids Res 2013;41:e150.

278 Mikel P, Vasickova P, Kralik P: Methods for preparation of MS2 phage-like particles and their utilization as process control viruses in RT-PCR and qRT-PCR detection of RNA viruses from food matrices and clinical specimens. Food Environ Virol DOI 10.1007/ s12560-015-9188-2. Published online: 25 February 2015.

279 Frietze K, Peabody D, Chackerian B: Engineering virus-like particles as vaccine platforms. Curr Opin Virol 2016;18:44-49.

280 Saboo S, Tumban E, Peabody J, Wafula D, Peabody DS, Chackerian B, Muttil P: An optimized formulation of a thermostable spray-dried virus-like particles vaccine against human papillomavirus. Mol Pharm 2016;13:1646-1655.

281 Prel A, Caval V, Gayon R, Ravassard P, Duthoit C, Payen E, Maouche-Chretien L, Creneguy A, Nguyen TH, Martin N, Piver E, Sevrain R, Lamouroux L, Leboulch P, Deschaseaux F, Bouillé $P$, Sensébé L, Pagès JC: Highly efficient in vitro and in vivo delivery of functional RNAs using new versatile MS2-chimeric retrovirus-like particles. Mol Ther Methods Clin Dev 2015;2:15039.

282 Frietze KM, Roden RB, Lee JH, Shi Y, Peabody DS, Chackerian B: Identification of anti-CA125 antibody responses in ovarian cancer patients by a novel deep sequencecoupled biopanning platform. Cancer Immunol Res 2016;4:157-164.

283 Witus LS, Francis MB: Using synthetically modified proteins to make new materials. Acc Chem Res 2011;44:774-783.

284 Stephanopoulos N, Liu M, Tong GJ, Li Z, Liu Y, Yan H, Francis MB: Immobilization and one-dimensional arrangement of virus capsids with nanoscale precision using DNA origami. Nano Lett 2010;10:2714-2720.
285 Wang D, Capehart SL, Pal S, Liu M, Zhang L, Schuck PJ, Liu Y, Yan H, Francis MB, De Yoreo JJ: Hierarchical assembly of plasmonic nanostructures using virus capsid scaffolds on DNA origami templates. ACS Nano 2014;8:7896-7904.

286 Friedman SD, Genthner FJ, Gentry J, Sobsey MD, Vinjé J: Gene mapping and phylogenetic analysis of the complete genome from 30 single-stranded RNA male-specific coliphages (family Leviviridae). J Virol 2009;83: 11233-11243.

287 Rumnieks J, Tars K: Diversity of pili-specific bacteriophages: genome sequence of IncM plasmid-dependent RNA phage M. BMC Microbiol 2012;12:277.

288 Kannoly S, Shao Y, Wang IN: Rethinking the evolution of single-stranded RNA (ssRNA) bacteriophages based on genomic sequences and characterizations of two R-plasmid-dependent ssRNA phages, C-1 and Hgall. J Bacteriol 2012;194:5073-5079.

289 Friedman SD, Snellgrove WC, Genthner FJ: Genomic sequences of two novel levivirus single-stranded RNA coliphages (family Leviviridae): evidence for recombination in environmental strains. Viruses 2012; 4: 1548-1568.

290 Vinjé J, Oudejans SJ, Stewart JR, Sobsey MD, Long SC: Molecular detection and genotyping of male-specific coliphages by reverse transcription-PCR and reverse line blot hybridization. Appl Environ Microbiol 2004; 70:5996-6004.

291 Greninger AL, DeRisi JL: Draft genome sequences of Leviviridae RNA phages EC and $M B$ recovered from San Francisco wastewater. Genome Announc 2015;3:e00652-15.

292 Krishnamurthy SR, Janowski AB, Zhao G, Barouch D, Wang D: Hyperexpansion of RNA bacteriophage diversity. PLoS Biol 2016;14:e1002409.

293 Dykeman EC, Stockley PG, Twarock R: Solving a Levinthal's paradox for virus assembly identifies a unique antiviral strategy. Proc Natl Acad Sci USA 2014;111:53615366.

294 Dika C, Duval JF, Ly-Chatain HM, Merlin C, Gantzer C: Impact of internal RNA on aggregation and electrokinetics of viruses: comparison between MS2 phage and corresponding virus-like particles. Appl Environ Microbiol 2011;77:4939-4948.

295 Schmitz N, Beerli RR, Bauer M, Jegerlehner A, Dietmeier K, Maudrich M, Pumpens P, Saudan P, Bachmann MF: Universal vaccine against influenza virus: Linking TLR signaling to anti-viral protection. Eur J Immunol 2012;42:863-869.

296 Crossey E, Amar MJ, Sampson M, Peabody J, Schiller JT, Chackerian B, Remaley AT: A cholesterol-lowering VLP vaccine that targets PCSK9. Vaccine 2015;33:5747-5755.

297 Dong YM, Zhang GG, Huang XJ, Chen L, Chen HT: Promising MS2 mediated viruslike particle vaccine against foot-and-mouth disease. Antiviral Res 2015;117:39-43. 
298 Stockley PG, Mastico RA: Use of fusions to viral coat proteins as antigenic carriers for vaccine development. Methods Enzymol 2000;326:551-569.

299 Lagoutte P, Mignon C, Donnat S, Stadthagen G, Mast J, Sodoyer R, Lugari A, Werle B: Scalable chromatography-based purification of virus-like particle carrier for epitope based influenza A vaccine produced in Escherichia coli. J Virol Methods 2016;232:8-11.

300 Caldeira J, Bustos J, Peabody J, Chackerian B, Peabody DS: Epitope-specific anti-hCG vaccines on a virus like particle platform. PLoS One 2015;10:e0141407.

301 Pastori C, Tudor D, Diomede L, Drillet AS, Jegerlehner A, Röhn TA, Bomsel M, Lopalco L: Virus like particle based strategy to elicit HIV-protective antibodies to the alpha-helic regions of gp41. Virology 2012;431:1-11.

302 Freer G, Giannecchini S, Tissot A, Bachmann MF, Rovero P, Serres PF, Bendinelli M: Dissection of seroreactivity against the tryptophan-rich motif of the feline immunodeficiency virus transmembrane glycoprotein. Virology 2004;322:360-369.

303 Huber A, Bachmann M, Jennings G, Tissot A, Langedijk J, Timmerman P, Slootstra J, Boshuizen R: Circular CCR5 peptide conjugates and uses thereof. WIPO Patent Application WO/2008/074895. June 26, 2008.

304 Sommerfelt MA: Circular CCR5 peptide conjugates and uses thereof (WO2008074895). Expert Opin Ther Pat 2009;19: 1323-1328.

305 Hunter Z, Smyth HD, Durfee P, Chackerian B: Induction of mucosal and systemic antibody responses against the HIV coreceptor CCR5 upon intramuscular immunization and aerosol delivery of a virus-like particle based vaccine. Vaccine 2009;28:403-414.

306 van Rompay KK, Hunter Z, Jayashankar K, Peabody J, Montefiori D, Labranche CC, Keele BF, Jensen K, Abel K, Chackerian B: A vaccine against CCR5 protects a subset of macaques upon intravaginal challenge with simian immunodeficiency virus SIVmac251. J Virol 2014;88:2011-2024.

307 Kündig TM, Senti G, Schnetzler G, Wolf C, Prinz Vavricka BM, Fulurija A, Hennecke F, Sladko K, Jennings GT, Bachmann MF: Der $\mathrm{p} 1$ peptide on virus-like particles is safe and highly immunogenic in healthy adults. J Allergy Clin Immunol 2006;117:1470-1476.

308 Schmitz N, Dietmeier K, Bauer M, Maudrich M, Utzinger S, Muntwiler S, Saudan P, Bachmann MF: Displaying Fel d1 on virus-like particles prevents reactogenicity despite greatly enhanced immunogenicity: a novel therapy for cat allergy. J Exp Med 2009;206: 1941-1955.

309 Akache B, Weeratna RD, Deora A, Thorn JM, Champion B, Merson JR, Davis HL, McCluskie MJ: Anti-IgE Q $\beta$-VLP conjugate vaccine self-adjuvants through activation of TLR7. Vaccines (Basel) 2016;4:3.
310 Araujo RN, Franco PF, Rodrigues H, Santos LC, McKay CS, Sanhueza CA, Brito CR, Azevedo MA, Venuto AP, Cowan PJ, Almeida IC, Finn MG, Marques AF: Amblyomma sculptum tick saliva: $\alpha-G a l$ identification, antibody response and possible association with red meat allergy in Brazil. Int J Parasitol 2016;46:213-220.

311 Chackerian B, Rangel M, Hunter Z, Peabody DS: Virus and virus-like particle-based immunogens for Alzheimer's disease induce antibody responses against amyloid- $\beta$ without concomitant $\mathrm{T}$ cell responses. Vaccine 2006;24:6321-6331.

312 Li QY, Gordon MN, Chackerian B, Alamed J, Ugen KE, Morgan D: Virus-like peptide vaccines against $A \beta \mathrm{N}$-terminal or $\mathrm{C}$-terminal domains reduce amyloid deposition in APP transgenic mice without addition of adjuvant. J Neuroimmune Pharmacol 2010;5: 133-142.

313 Wiessner C, Wiederhold KH, Tissot AC, Frey P, Danner S, Jacobson LH, Jennings GT, Lüönd R, Ortmann R, Reichwald J, Zurini M, Mir A, Bachmann MF, Staufenbiel $M$ : The second-generation active $A \beta$ immunotherapy CAD106 reduces amyloid accumulation in APP transgenic mice while minimizing potential side effects. J Neurosci 2011;31:9323-9331.

314 Tissot AC, Spohn G, Jennings GT, Shamshiev A, Kurrer MO, Windak R, Meier M, Viesti M, Hersberger M, Kündig TM, Ricci R, Bachmann MF: A VLP-based vaccine against interleukin-1 $\alpha$ protects mice from atherosclerosis. Eur J Immunol 2013;43: 716-722.

315 Spohn G, Keller I, Beck M, Grest P, Jennings GT, Bachmann MF: Active immunization with IL-1 displayed on virus-like particles protects from autoimmune arthritis. Eur J Immunol 2008;38:877-887.

316 Guler R, Parihar SP, Spohn G, Johansen P, Brombacher F, Bachmann MF: Blocking IL$1 \alpha$ but not IL-1 $\beta$ increases susceptibility to chronic Mycobacterium tuberculosis infection in mice. Vaccine 2011;29:1339-1346.

317 Röhn TA, Jennings GT, Hernandez M, Grest P, Beck M, Zou Y, Kopf M, Bachmann MF: Vaccination against IL-17 suppresses autoimmune arthritis and encephalomyelitis. Eur J Immunol 2006;36:2857-2867.

318 Sonderegger I, Röhn TA, Kurrer MO, Iezzi G, Zou Y, Kastelein RA, Bachmann MF, Kopf M: Neutralization of IL-17 by active vaccination inhibits IL-23-dependent autoimmune myocarditis. Eur J Immunol 2006; 36:2849-2856.

319 Dallenbach K, Maurer P, Röhn T, Zabel F, Kopf M, Bachmann MF: Protective effect of a germline, IL-17-neutralizing antibody in murine models of autoimmune inflammatory disease. Eur J Immunol 2015;45:12381247.
320 Spohn G, Guler R, Johansen P, Keller I, Jacobs M, Beck M, Rohner F, Bauer M, Dietmeier K, Kündig TM, Jennings GT, Brombacher F, Bachmann MF: A virus-like particle-based vaccine selectively targeting soluble TNF- $\alpha$ protects from arthritis without inducing reactivation of latent tuberculosis. J Immunol 2007;178:7450-7457.

321 Spohn G, Schori C, Keller I, Sladko K, Sina C, Guler R, Schwarz K, Johansen P, Jennings GT, Bachmann MF: Preclinical efficacy and safety of an anti-IL- $1 \beta$ vaccine for the treatment of type 2 diabetes. Mol Ther Methods Clin Dev 2014;1:14048.

322 Cavelti-Weder C, Timper K, Seelig E, Keller C, Osranek M, Lässing U, Spohn G, Maurer $P$, Müller P, Jennings GT, Willers J, Saudan P, Donath MY, Bachmann MF: Development of an interleukin- $1 \beta$ vaccine in patients with type 2 diabetes. Mol Ther 2016; 24:1003-1012.

323 Zou Y, Sonderegger I, Lipowsky G, Jennings GT, Schmitz N, Landi M, Kopf M, Bachmann MF: Combined vaccination against IL-5 and eotaxin blocks eosinophilia in mice. Vaccine 2010;28:3192-3200.

324 Chackerian B, Durfee MR, Schiller JT: Virus-like display of a neo-self antigen reverses $B$ cell anergy in a B cell receptor transgenic mouse model. J Immunol 2008;180:58165825.

325 Ambühl PM, Tissot AC, Fulurija A, Maurer P, Nussberger J, Sabat R, Nief V, Schellekens C, Sladko K, Roubicek K, Pfister T, Rettenbacher M, Volk HD, Wagner F, Müller P, Jennings GT, Bachmann MF: A vaccine for hypertension based on virus-like particles: preclinical efficacy and phase I safety and immunogenicity. J Hypertens 2007;25:6372.

326 Tissot AC, Maurer P, Nussberger J, Sabat R, Pfister T, Ignatenko S, Volk HD, Stocker $\mathrm{H}$ Müller P, Jennings GT, Wagner F, Bachmann MF: Effect of immunisation against angiotensin II with CYT006-AngQb on ambulatory blood pressure: a double-blind, randomised, placebo-controlled phase IIa study. Lancet 2008;371:821-827.

327 Chen X, Qiu Z, Yang S, Ding D, Chen F, Zhou Y, Wang M, Lin J, Yu X, Zhou Z, Liao Y: Effectiveness and safety of a therapeutic vaccine against angiotensin II receptor type 1 in hypertensive animals. Hypertension 2013;61:408-416.

328 Ding D, Du Y, Qiu Z, Yan S, Chen F, Wang M, Yang S, Zhou Y, Hu X, Deng Y, Wang S, Wang L, Zhang $\mathrm{H}$, Wu H, Yu X, Zhou Z, Liao Y, Chen X: Vaccination against type 1 angiotensin receptor prevents streptozotocin-induced diabetic nephropathy. J Mol Med 2016;94:207-218.

329 Zhou Y, Wang S, Qiu Z, Song X, Pan Y, Hu $\mathrm{X}$, Zhang H, Deng Y, Ding D, Wu H, Yang S, Wang $M$, Zhou Z, Liao $Y$, Chen X: ATRQ $\beta-001$ vaccine prevents atherosclerosis in apolipoprotein E-null mice. J Hypertens 2016;34:474-485. 
330 Röhn TA, Ralvenius WT, Paul J, Borter P, Hernandez M, Witschi R, Grest P, Zeilhofer HU, Bachmann MF, Jennings GT: A viruslike particle-based anti-nerve growth factor vaccine reduces inflammatory hyperalgesia: potential long-term therapy for chronic pain. J Immunol 2011;186:1769-1780.

331 Skibinski DA, Hanson BJ, Lin Y, von Messling V, Jegerlehner A, Tee JB, Chye de $\mathrm{H}$, Wong SK, Ng AA, Lee HY, Au B, Lee BT, Santoso L, Poidinger M, Fairhurst AM, Matter A, Bachmann MF, Saudan P, Connolly JE: Enhanced neutralizing antibody titers and Th1 polarization from a novel Escherichia coli derived pandemic influenza vaccine. PLoS One 2013;8:e76571.

332 Jegerlehner A, Zabel F, Langer A, Dietmeier K, Jennings GT, Saudan P, Bachmann MF: Bacterially produced recombinant influenza vaccines based on virus-like particles. PLoS One 2013;8:e78947.

333 Low JG, Lee LS, Ooi EE, Ethirajulu K, Yeo P, Matter A, Connolly JE, Skibinski DA, Saudan P, Bachmann M, Hanson BJ, Lu Q, MaurerStroh S, Lim S, Novotny-Diermayr V: Safety and immunogenicity of a virus-like particle pandemic influenza A (H1N1) 2009 vaccine: results from a double-blinded, randomized phase I clinical trial in healthy Asian volunteers. Vaccine 2014;32:5041-5048.

334 Khan F, Porter M, Schwenk R, DeBot M, Saudan P, Dutta S: Head-to-head comparison of soluble vs. Q $\beta$ VLP circumsporozoite protein vaccines reveals selective enhancement of NANP repeat responses. PLoS One 2015;10:e0142035.

335 Speiser DE, Schwarz K, Baumgaertner P, Manolova V, Devevre E, Sterry W, Walden P, Zippelius A, Conzett KB, Senti G, Voelter V, Cerottini JP, Guggisberg D, Willers J, Geldhof C, Romero P, Kündig T, Knuth A, Dummer R, Trefzer U, Bachmann MF: Memory and effector CD8 T-cell responses after nanoparticle vaccination of melanoma patients. J Immunother 2010;33:848-858.

336 Braun M, Jandus C, Maurer P, HammannHaenni A, Schwarz K, Bachmann MF, Speiser DE, Romero P: Virus-like particles induce robust human T-helper cell responses. Eur J Immunol 2012;42:330-340.

337 Goldinger SM, Dummer R, Baumgaertner P, Mihic-Probst D, Schwarz K, HammannHaenni A, Willers J, Geldhof C, Prior JO, Kündig TM, Michielin O, Bachmann MF, Speiser DE: Nano-particle vaccination combined with TLR-7 and -9 ligands triggers memory and effector CD8-T-cell responses in melanoma patients. Eur J Immunol 2012; 42:3049-3061.

338 McCluskie MJ, Thorn J, Gervais DP, Stead DR, Zhang N, Benoit M, Cartier J, Kim IJ, Bhattacharya K, Finneman JI, Merson JR, Davis HL: Anti-nicotine vaccines: comparison of adjuvanted CRM197 and Q $\beta$-VLP conjugate formulations for immunogenicity and function in non-human primates. Int Immunopharmacol 2015;29:663-671.
339 Fulurija A, Lutz TA, Sladko K, Osto M, Wielinga PY, Bachmann MF, Saudan P: Vaccination against GIP for the treatment of obesity. PLoS One 2008;3:e3163.

340 Spohn G, Schwarz K, Maurer P, Illges H, Rajasekaran N, Choi Y, Jennings GT, Bachmann MF: Protection against osteoporosis by active immunization with TRANCE/ RANKL displayed on virus-like particles. J Immunol 2005;175:6211-6218.

341 Kalniņš G, Cielēns I, Renhofa R: Virus-like particles addressed by HBV preS1 sequences. Environ Exp Biol 2013;11:1-8.

342 Rūmnieks J, Freivalds J, Cielēns I, Renhofa R: Specificity of packaging mRNAs in bacteriophage GA virus-like particles in yeast $\mathrm{Sac}$ charomyces cerevisiae. Acta Universitatis Latviensis Biol 2008;745:145-154.

343 Strods A, Ārgule D, Cielēns I, Jackeviča L, Renhofa R: Expression of GA coat proteinderived mosaic virus-like particles in Saccharomyces cerevisiae and packaging in vivo of mRNAs into particles. Proc Latv Acad Sci 2012;66:234-241.

344 Ārgule D, Cielēns I, Renhofa R, Strods A: In vivo packaging of yeast-produced bacteriophage GA derived virus-like particles. Proc Latv Acad Sci 2016, in press.

345 Wu M, Sherwin T, Brown WL, Stockley PG: Delivery of antisense oligonucleotides to leukemia cells by RNA bacteriophage capsids. Nanomedicine 2005;1:67-76.

346 Wei B, Wei Y, Zhang K, Wang J, Xu R, Zhan S, Lin G, Wang W, Liu M, Wang L, Zhang R, Li J: Development of an antisense RNA delivery system using conjugates of the MS2 bacteriophage capsids and HIV-1 TAT cellpenetrating peptide. Biomed Pharmacother 2009;63:313-318.

347 Pan Y, Zhang Y, Jia T, Zhang K, Li J, Wang L: Development of a microRNA delivery system based on bacteriophage MS2 virus-like particles. FEBS J 2012;279:11981208.

348 Pan Y, Jia T, Zhang Y, Zhang K, Zhang R, Li J, Wang L: MS2 VLP-based delivery of microRNA-146a inhibits autoantibody production in lupus-prone mice. Int J Nanomedicine 2012;7:5957-5967.

349 Yao Y, Jia T, Pan Y, Gou H, Li Y, Sun Y, Zhang R, Zhang K, Lin G, Xie J, Li J, Wang L: Using a novel microRNA delivery system to inhibit osteoclastogenesis. Int J Mol Sci 2015; 16:8337-8350.

350 Galaway FA, Stockley PG: MS2 viruslike particles: a robust, semisynthetic targeted drug delivery platform. Mol Pharm 2013;10: 59-68.

351 Capehart SL, Coyle MP, Glasgow JE, Francis MB: Controlled integration of gold nanoparticles and organic fluorophores using synthetically modified MS2 viral capsids. J Am Chem Soc 2013;135:3011-3016.

352 Cohen BA, Bergkvist M: Targeted in vitro photodynamic therapy via aptamer-labeled, porphyrin-loaded virus capsids. J Photochem Photobiol B 2013;121:67-74.
353 ElSohly AM, Netirojjanakul C, Aanei IL, Jager A, Bendall SC, Farkas ME, Nolan GP, Francis MB: Synthetically modified viral capsids as versatile carriers for use in antibody-based cell targeting. Bioconjug Chem 2015;26:1590-1596.

354 Chang L, Wang G, Jia T, Zhang L, Li Y, Han Y, Zhang K, Lin G, Zhang R, Li J, Wang L: Armored long non-coding RNA MEG3 targeting EGFR based on recombinant MS2 bacteriophage virus-like particles against hepatocellular carcinoma. Oncotarget 2016; 7:23988-24004

355 Sun S, Li W, Sun Y, Pan Y, Li J: A new RNA vaccine platform based on MS2 virus-like particles produced in Saccharomyces cerevisiae. Biochem Biophys Res Commun 2011; 407:124-128.

356 Glasgow JE, Capehart SL, Francis MB, Tullman-Ercek D: Osmolyte-mediated encapsulation of proteins inside MS2 viral capsids. ACS Nano 2012;6:8658-8664.

357 Li J, Sun Y, Jia T, Zhang R, Zhang K, Wang $\mathrm{L}$ : Messenger RNA vaccine based on recombinant MS2 virus-like particles against prostate cancer. Int J Cancer 2014;134:16831694.

358 Steinmetz NF, Hong V, Spoerke ED, Lu P, Breitenkamp K, Finn MG, Manchester M: Buckyballs meet viral nanoparticles: candidates for biomedicine. J Am Chem Soc 2009; 131:17093-17095.

359 Rhee JK, Hovlid M, Fiedler JD, Brown SD, Manzenrieder F, Kitagishi H, Nycholat C, Paulson JC, Finn MG: Colorful virus-like particles: fluorescent protein packaging by the $\mathrm{Q} \beta$ capsid. Biomacromolecules 2011;12: 3977-3981.

360 Rhee JK, Baksh M, Nycholat C, Paulson JC, Kitagishi H, Finn MG: Glycan-targeted virus-like nanoparticles for photodynamic therapy. Biomacromolecules 2012;13:23332338.

361 Lau JL, Baksh MM, Fiedler JD, Brown SD, Kussrow A, Bornhop DJ, Ordoukhanian P, Finn MG: Evolution and protein packaging of small-molecule RNA aptamers. ACS Nano 2011;5:7722-7729.

362 Wu Z, Tang LJ, Zhang XB, Jiang JH, Tan W: Aptamer-modified nanodrug delivery systems. ACS Nano 2011;5:7696-7699.

363 Hovlid ML, Lau JL, Breitenkamp K, Higginson CJ, Laufer B, Manchester M, Finn MG: Encapsidated atom-transfer radical polymerization in $\mathrm{Q} \beta$ virus-like nanoparticles. ACS Nano 2014;8:8003-8014.

364 Fiedler JD, Brown SD, Lau JL, Finn MG RNA-directed packaging of enzymes within virus-like particles. Angew Chem Int Ed Engl 2010;49:9648-9651.

365 Hong V, Udit AK, Evans RA, Finn MG: Electrochemically protected copper(I)-catalyzed azide-alkyne cycloaddition. Chembiochem 2008:9:1481-1486. 
366 Kaltgrad E, O’Reilly MK, Liao L, Han S, Paulson JC, Finn MG: On-virus construction of polyvalent glycan ligands for cell-surface receptors. J Am Chem Soc 2008; 130: 4578-4579.

367 Kussrow A, Kaltgrad E, Wolfenden ML, Cloninger MJ, Finn MG, Bornhop DJ: Measurement of monovalent and polyvalent carbohydrate-lectin binding by back-scattering interferometry. Anal Chem 2009;81:48894897.

368 Udit AK, Everett C, Gale AJ, Reiber Kyle J, Ozkan M, Finn MG: Heparin antagonism by polyvalent display of cationic motifs on virus-like particles. Chembiochem 2009;10: 503-510.

369 Gale AJ, Elias DJ, Averell PM, Teirstein PS, Buck M, Brown SD, Polonskaya Z, Udit AK, Finn MG: Engineered virus-like nanoparticles reverse heparin anticoagulation more consistently than protamine in plasma from heparin-treated patients. Thromb Res 2011; 128:e9-13.

370 Udit AK: Engineered virus-like nanoparticle heparin antagonists. Conf Proc IEEE Eng Med Biol Soc 2013;2013:4118-4120.

371 Brown SD, Fiedler JD, Finn MG: Assembly of hybrid bacteriophage $Q \beta$ virus-like particles. Biochemistry 2009;48:11155-11157.

372 Astronomo RD, Kaltgrad E, Udit AK, Wang SK, Doores KJ, Huang CY, Pantophlet R, Paulson JC, Wong CH, Finn MG, Burton DR: Defining criteria for oligomannose immunogens for HIV using icosahedral virus capsid scaffolds. Chem Biol 2010;17:357370.

373 Banerjee D, Liu AP, Voss NR, Schmid SL, Finn MG: Multivalent display and receptormediated endocytosis of transferrin on virus-like particles. Chembiochem 2010;11: 1273-1279.
374 Cigler P, Lytton-Jean AK, Anderson DG, Finn MG, Park SY: DNA-controlled assembly of a NaTl lattice structure from gold nanoparticles and protein nanoparticles. Nat Mater 2010;9:918-922.

375 Manzenrieder F, Luxenhofer R, Retzlaff M, Jordan R, Finn MG: Stabilization of viruslike particles with poly(2-oxazoline)s. Angew Chem Int Ed Engl 2011;50:2601-2605.

376 Pokorski JK, Breitenkamp K, Liepold LO, Qazi S, Finn MG: Functional virus-based polymer-protein nanoparticles by atom transfer radical polymerization. J Am Chem Soc 2011;133:9242-9245.

377 Pokorski JK, Hovlid ML, Finn MG: Cell targeting with hybrid $\mathrm{Q} \beta$ virus-like particles displaying epidermal growth factor. Chembiochem 2011;12:2441-2447.

378 Mead G, Hiley M, Ng T, Fihn C, Hong K, Groner M, Miner W, Drugan D, Hollingsworth W, Udit AK: Directed polyvalent display of sulfated ligands on virus nanoparticles elicits heparin-like anticoagulant activity. Bioconjug Chem 2014;25:1444-1452.

379 Groner M, Ng T, Wang W, Udit AK: Biolayer interferometry of a multivalent sulfated virus nanoparticle with heparin-like anticoagulant activity. Anal Bioanal Chem 2015; 407:5843-5847.

380 Isarov SA, Lee PW, Pokorski JK: 'Graft-to' protein/polymer conjugates using polynorbornene block copolymers. Biomacromolecules 2016;17:641-648.

381 Kang JS, Yoon JH: Dynamics of RNA bacteriophage MS2 observed with a long-lifetime metal-ligand complex. J Photosci 2004;11: 35-40.

382 Datta A, Hooker JM, Botta M, Francis MB, Aime S, Raymond KN: High relaxivity gadolinium hydroxypyridonate-viral capsid conjugates: nanosized MRI contrast agents. J Am Chem Soc 2008;130:2546-2552.
383 Meldrum T, Seim KL, Bajaj VS, Palaniappan $\mathrm{KK}, \mathrm{Wu} \mathrm{W}$, Francis MB, Wemmer DE, Pines A: A xenon-based molecular sensor assembled on an MS2 viral capsid scaffold. J Am Chem Soc 2010;132:5936-5937.

384 Farkas ME, Aanei IL, Behrens CR, Tong GJ, Murphy ST, O’Neil JP, Francis MB: PET imaging and biodistribution of chemically modified bacteriophage MS2. Mol Pharm 2013;10:69-76.

385 Obermeyer AC, Capehart SL, Jarman JB, Francis MB: Multivalent viral capsids with internal cargo for fibrin imaging. PLoS One 2014;9:e100678.

386 Elena CM, Leticia F, Emilia T, Patricia E, Mariella T: Evaluation of a labelled bacteriophage with ${ }^{99 \mathrm{~m}} \mathrm{Tc}$ as a potential agent for infection diagnosis. Curr Radiopharm 2016;9: 137-142.

387 Prasuhn DE Jr, Singh P, Strable E, Brown S, Manchester M, Finn MG: Plasma clearance of bacteriophage $\mathrm{Q} \beta$ particles as a function of surface charge. J Am Chem Soc 2008; 130 : 1328-1334.

388 Kim MS, Kim JH, Son BW, Kang JS: Dynamics of bacteriophage R17 probed with a longlifetime $\mathrm{Ru}(\mathrm{II})$ metal-ligand complex. J Fluoresc 2010;20:713-718.

389 Carrillo-Tripp M, Shepherd CM, Borelli IA, Venkataraman S, Lander G, Natarajan P, Johnson JE, Brooks CL 3rd, Reddy VS: VIPERdb2: an enhanced and web API enabled relational database for structural virology. Nucleic Acids Res 2009;37:D436-D442.

390 Pettersen EF, Goddard TD, Huang CC, Couch GS, Greenblatt DM, Meng EC, Ferrin TE: UCSF Chimera - a visualization system for exploratory research and analysis. J Comput Chem 2004;25:1605-1612. 